\title{
Poverty in the Brazilian Amazon: An Assessment of Poverty Focused on the State of Pará
}

By

\author{
Dorte Verner ${ }^{1}$ \\ World Bank
}

World Bank Policy Research Working Paper 3357, July 2004

The Policy Research Working Paper Series disseminates the findings of work in progress to encourage the exchange of ideas about development issues. An objective of the series is to get the findings out quickly, even if the presentations are less than fully polished. The papers carry the names of the authors and should be cited accordingly. The findings, interpretations, and conclusions expressed in this paper are entirely those of the authors. They do not necessarily represent the view of the World Bank, its Executive Directors, or the countries they represent. Policy Research Working Papers are available online at http://econ.worldbank.org.

\footnotetext{
${ }^{1}$ I am very grateful to Lucy Leão and Vilmos Gruvald and their teams from the state government of Pará for assistance on data and other information, Rodolfo Villela Marino for excellent and invaluable research assistance, Lucilene Anderson and Grissel Prieto for office support. The findings, interpretations, and conclusions expressed in this paper are entirely those of the author and should not be associated with the World Bank or its member countries.
} 


\begin{abstract}
The states in the Brazilian Amazon have made progress in reducing poverty and improving social indicators in the last decade. Despite this progress, the poverty rate in the Amazon is among the highest in Brazil. As of 2000, rural poverty is the greatest challenge. In Pará, not only is the headcount poverty rate of 58.4 percent in rural areas more than 55 percent higher than headcount poverty in urban areas, but also poverty is much deeper in rural areas. The fall in infant mortality and adult illiteracy corroborate the improvement in measured income poverty. Census data from 2000 and 1991 reveal that more people left Pará than came to live in the state during the 1970s, the opposite of the 1980s. In 2000, the Gini coefficient for Pará, as in the Amazon as a whole, was 0.60. The poverty profile reveals that indigenous peoples experience a higher poverty incidence than other groups.

Census 2000 data reveal that living in rural areas in Pará does not by itself affect the probability of being poor. Individual and household characteristics are more important than geographical location. The largest statistical differences in poverty reduction between rural and urban areas are found in the effect of education, sector of employment, gender, and family size. PNAD data from 2001 reveal that living in urban areas in Pará does not by itself affect the probability of falling below the poverty line in urban areas in Brazil. The strongest poverty correlates are education, experience, race, rural location, gender, and labor market association.
\end{abstract}




\section{MAPS OF THE STATE OF PARÁ}

\section{MESO REGIONS}

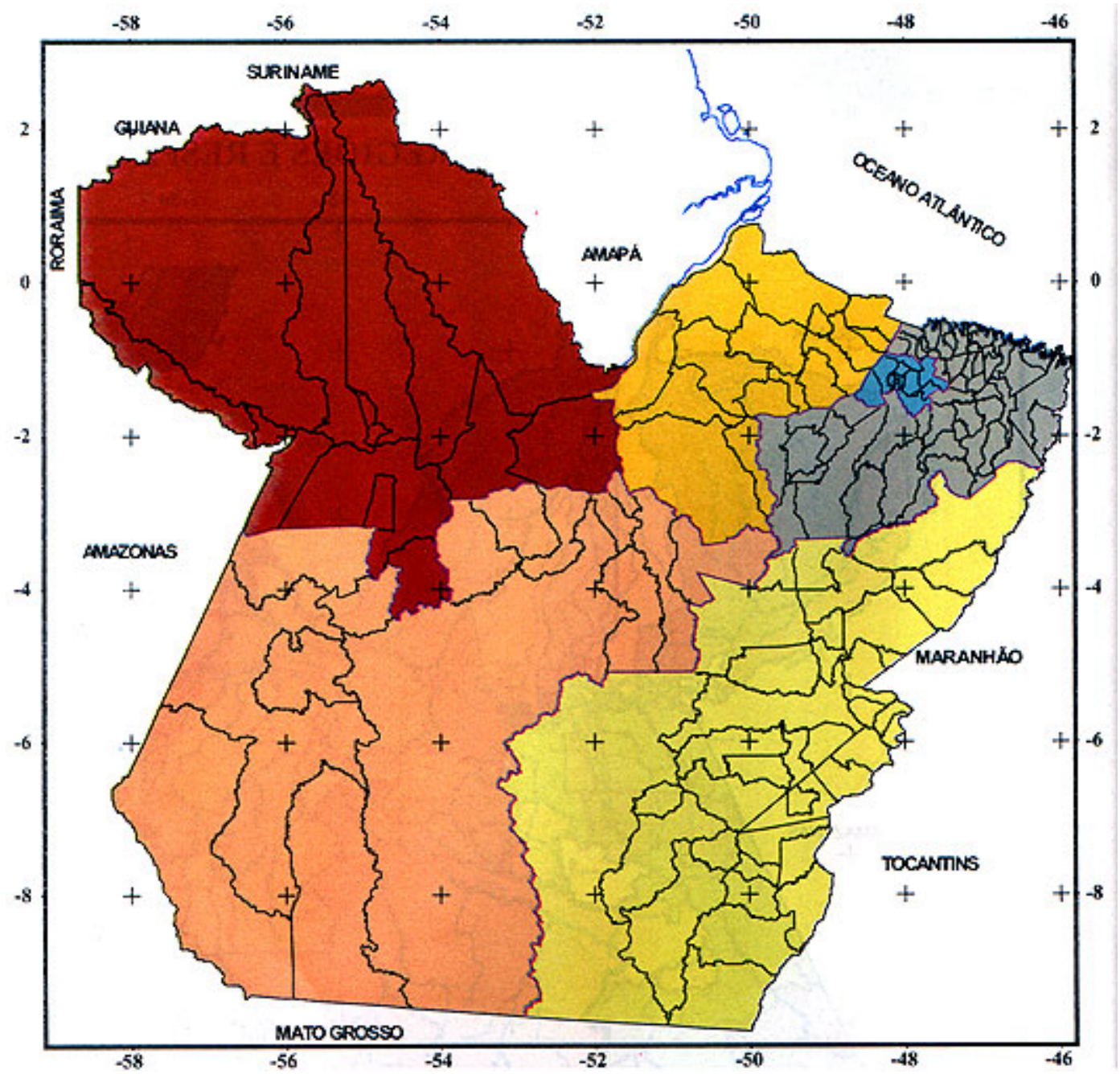

Source: IBGE. 
PARÁ

\section{MICRO REGIONS}

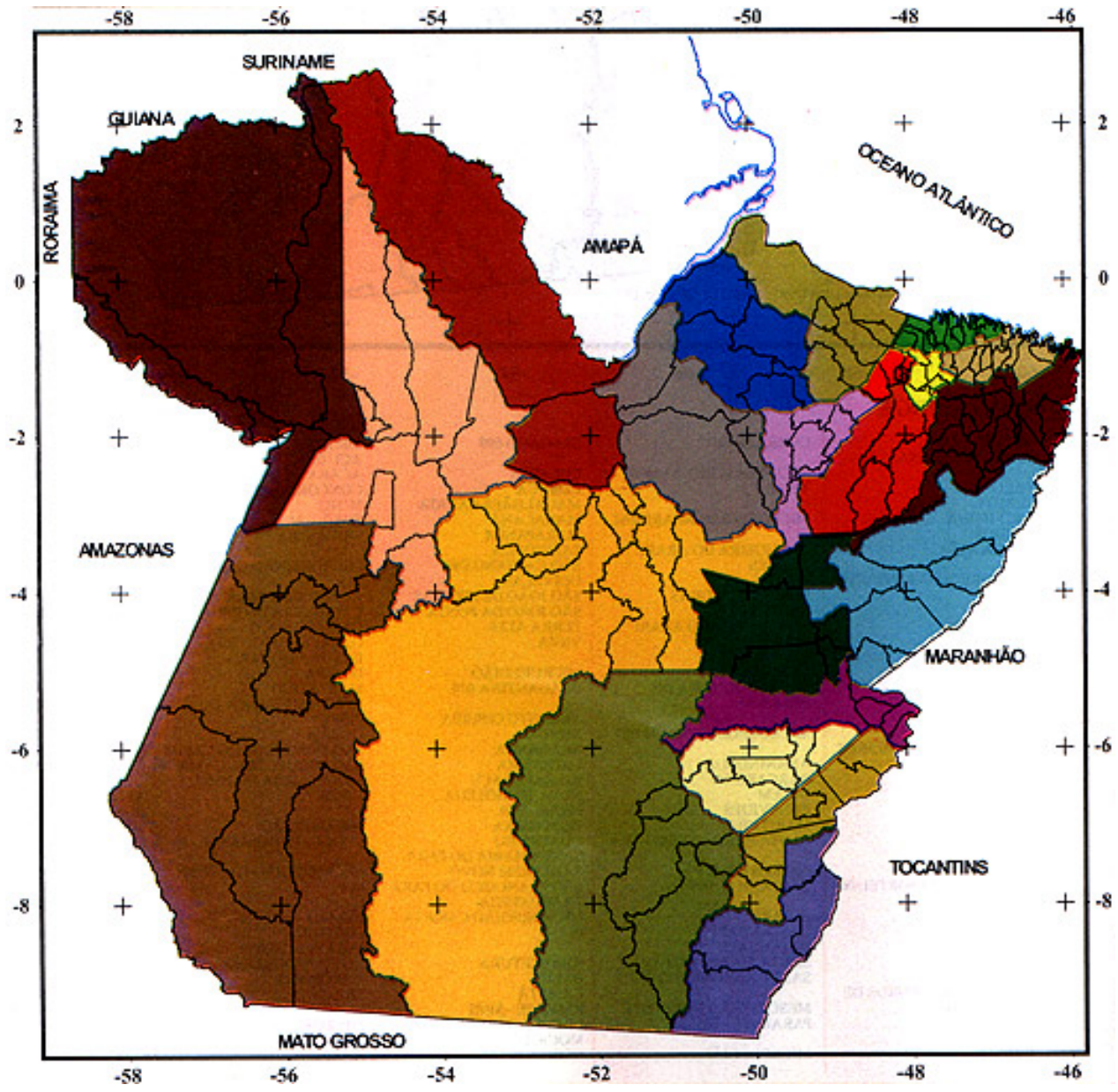

Source: IBGE. 


\section{Introduction}

Pará is a rich state and is arguably the most advanced state in the Amazon. It has natural resources; a large part of the state is still covered with rainforest and a rich biodiversity; and the state has many skilled and talented people. Furthermore, during the last decades, Pará has transformed itself from an economy based on rubber to a diversified economy and one of the leading states of the North of Brazil. In this process, the state government has moved toward being more modern and fiscally responsible in its administration. Nevertheless, Pará lags behind other states in the Amazon in social welfare and distribution of income and assets. Although it has natural resources and a large part of the state is still covered with rainforest, poverty is widespread and deep in rural and urban areas.

In Pará, progress in poverty reduction, social indicators and social inclusion has taken place in the last decades as elsewhere in Brazil. This is mainly due to the recent growth of the economy, demographic changes, and macroeconomic stabilization. However, poverty in Pará is still broad and deep, and as of 2000, Pará remains one of the poorest states in Brazil. In Pará, rural poverty is the greatest challenge for the government. Not only is the headcount poverty rate of 58.4 percent in rural areas more than 55 percent higher than the headcount poverty rate of 38 percent in urban areas, but poverty is also much deeper in rural areas; the squared poverty gap measure of 24.7 is 113 percent higher than in urban areas. Therefore, more needs to be done to ensure a better life for those who are vulnerable in rural areas. With decisive action, Pará could continue to build on its recent achievements.

Reducing poverty is one of the central challenges in Pará. Given the heterogeneity of the poor in terms of income sources, human resources, and physical endowments, there is no single or simple solution to poverty reduction. This paper finds that a poverty reduction strategy for Pará must include different exit paths for different households, via a set of integrated policies tailored to capitalize on heterogeneous living conditions. Policy reforms need to be carried out simultaneously in different areas. The policies must be aimed at enhancing economic growth and employment, which are key to sustainable poverty reduction, as well as targeted poverty alleviation programs aimed at more directly assisting the poor. There is also merit to analytical work that serves as an important instrument to improve the quality of public policy-making and monitoring and evaluating public programs and policies to see the extent to which they are meeting their objectives and whether their design needs to be changed.

Over the medium to long run what is needed to alleviate the high levels of poverty and social exclusion is broad-based growth. In the short-run, measures are needed to protect vulnerable groups and to ensure that the poor are able to take advantage of the greater opportunities in the economy. The government of Pará has taken important steps to reduce poverty. However, Pará needs a rural poverty alleviation strategy that sets clear and appropriate priorities and goals for poverty reduction efforts. The strategic principles for reducing poverty involve seeking to strengthen the key assets of the poor, taking into account geographic differences in the poverty situation and priorities. The government of Pará could apply a five-pronged poverty-reduction approach. First, targeted programs should focus on the extreme poor and prioritize among groups. Second, Pará should reallocate public expenditures and promote community participation in service delivery. Third, it should implement key policy 
reforms to reduce disparities in assets. Fourth, it should improve targeting mechanisms. Fifth, it should allocate resources to monitor poverty and evaluate the implementation of poverty reduction interventions.

The paper is organized in eight sections. Section 2 outlines briefly the geography and economy, people, and demographic development. Section 3 outlines the data and methodology applied in the paper. Section 4 addresses poverty, income inequality, and quality of life, and Section 5 constructs a poverty profile of Pará. Section 6 addresses the question of assets, including employment, education and social safety nets. Section 7 analyzes poverty correlates in Pará. Finally, Section 8 proposes a six-pronged poverty-reduction strategy for Pará.

\section{Geography, People, and Growth}

This section outlines what can serve as a base for a poverty reduction strategy in Pará, namely geography and economy, people, and demographics. Individual and household assets, in particular human capital and labor market association, are other important poverty reducing factors are analyzed in Sections 5, 6, and 7.

\section{GEOGRAPHY AND ECONOMY}

Pará is the second largest state in Brazil. Pará covers an area of 1.24 million square kilometers in the Amazon. This is, around 45 percent of the area of the northern region and 14.6 percent of Brazil's total area. Pará is roughly the size of Peru and Colombia and it is only smaller in size than the neighboring state of Amazonas. Pará's area is divided into 143 municipalities (see Appendix A) and these into six meso regions, the largest being the Southeast region (see Table 2.1).

\begin{tabular}{|l|c|c|}
\hline \multirow{2}{*}{ Table 2.1: } & \multicolumn{2}{|c|}{ Territorial Area per Meso region, 2000 } \\
\hline & \multicolumn{2}{|c|}{ Area $\left(\mathbf{K m}^{\mathbf{2}}\right)$} \\
\cline { 2 - 3 } & Absolute Value & Percentage \\
\hline \multirow{2}{*}{ Pará } & $\mathbf{1 , 2 4 7 , 7 0 2 . 7}$ & $\mathbf{1 0 0 . 0}$ \\
Baixo Amazonas & $340,446.9$ & 27.3 \\
Marajó & $104,141.5$ & 8.4 \\
Metropolitan Belém & $6,875.5$ & 0.6 \\
Northeast Pará & $83,182.6$ & 6.7 \\
Southeast Pará & $415,775.9$ & 33.3 \\
Southwest Pará & $297,280.4$ & 23.3 \\
\hline Source: SEOF/DIEEST/BDE. & \multicolumn{2}{|c}{} \\
\hline
\end{tabular}

Pará's coastline is $562 \mathrm{~km}$ long and the state contains 40 percent of the interior waters of Brazil. The majority of Pará's vegetation ( 80 percent) is forest (Floresta de Terra Firm). Another 10 percent is Áreas alteradas por atividades Antrópica and the remaining is divided between cerrado, fields, and forest areas that are flooded part of 
the year (Floresta de Igapó). Finally, 35 percent of Pará's area is protected, where 75 percent are for Indian use.

Economic growth is an essential component of a poverty reduction strategy (World Bank 2002). In 2000, the GDP of Pará accounted for 1.8 percent of the total Brazilian GDP and 37 percent of the GDP of the North region, equivalent to R $\$ 18.9$ billion. During 1991-2000, Pará's economy grew at an average annual rate of 2.4 percent. This is not enough to reduce poverty, given that the population expands at around 2.5 percent per year (see below). Pará's economy is slightly a dual where, on the one hand, services contribute 49 percent of GDP, accounting for 63 percent of employment and manufacturing, and on the other hand, it contributes 29 percent of GDP, but only 16 percent of jobs (Table 2.2).

\begin{tabular}{|l|c|c|c|}
\hline \multirow{2}{*}{ Table 2.2: } & \multicolumn{3}{c|}{} \\
\hline Sector & \multicolumn{2}{|c|}{ Yectoral Trends in Pará's Economy, 1995-2000 } \\
\cline { 2 - 4 } & $\mathbf{1 9 9 5}$ & $\mathbf{2 0 0 0}$ & Variation \\
\hline Agriculture & 29.31 & 23.08 & -6.23 \\
Mining & 3.09 & 4.08 & 0.99 \\
Manufacturing & 14.90 & 14.48 & -0.42 \\
Public Utilities & 1.44 & 1.14 & -0.30 \\
Construction & 11.98 & 11.07 & -0.91 \\
Commerce & 7.30 & 6.18 & -1.12 \\
Housing and Food & 0.50 & 0.67 & 0.17 \\
Transport and Storage & 1.62 & 2.12 & 0.50 \\
Communication & 0.93 & 1.91 & 0.98 \\
Finance & 1.60 & 2.70 & 1.10 \\
Rent & 6.44 & 9.35 & 2.91 \\
Public Administration & 16.41 & 17.97 & 1.56 \\
Health and Education & 2.02 & 2.74 & 0.72 \\
Other Services & 2.12 & 2.11 & -0.01 \\
Domestic Services & 0.35 & 0.40 & 0.05 \\
\hline Source: SEOF/ DIEEST/COPASE. & & \\
\hline
\end{tabular}

In Pará, export revenues are among the highest in Brazil. Pará's industrial and trade poles and geographical location allows the state easy access to the foreign markets, such as the U.S. and European markets. In the nineteenth century Pará, was one of the preeminent states of Brazil. Rubber exports were the foundation for the development of the state and the driving force in the economy. Even today exports are far larger than imports. In 2002, the state achieved a trade surplus of US\$ 2.0 billion and was the fourth largest exporter of the 27 Brazilian states. Two commodities, iron and aluminum, accounted for 53 percent of all the export revenues of US\$2.3 billion.

\section{PEOPLE AND THEIR LIFESTYLE}

Pará's population of 6.2 million, 3.7 percent of Brazil's total, counts many indigenous groups, Caboclos, Quilombolas, and migrants form other states in Brazil, and European descendants. Its people are very knowledgeable of the natural world and have adapted to a lifestyle with difficult access to modern services in many locations. This section is based on own observations, discussions with people in Pará, and Amazon (2002). 


\section{Caboclos}

In Pará, as elsewhere in the region, there are Caboclos living beside the rivers. Many depend entirely on the river and floodplain (várzea), and cultivate crops on non-flooded areas (terra firme). The life of Caboclos is strongly influenced by the annual cycle of the river and streams. In the dry season, they cultivate beans or corn on river margins. In some places, there are cattle, which must be moved during floods to terra firme or kept on rafts.

The Caboclos live in palm-thatched houses built on stilts or float and have a raised garden, which is protected from the floods. The households tend gardens and grow manioc (from which they make flour), corn, sweet potato, plantains, pineapples, and papaya. They also grow fruit and raise chickens. Moreover, Brazil nuts and peach palm are harvested seasonally. ${ }^{2}$ The Caboclos depend on fruits from the forest and fishing for their livelihood. Finally, in the dry season, they catch turtles. Their diet generally consists of cassava flour mixed with fish.

Most settlers use small dugout canoes as means of transportation. In more frequently traveled sections of the rivers it is plied by small launches. Many Riberinhos mentioned that during the dry season their life becomes difficult, as many parts of the river system dry-up and the settlements are cut-off from any transport service. Then, dwellers have to walk for many hours on the sand to reach a village. Therefore, in some areas, such as around Óbidos in western Pará, small roads on terra firme would improve the access to services and livelihood of small communities. Access to public services is difficult, e.g. health posts, electricity, and infrastructure. Where there are groups of people living, primary schools may be found.

\section{Quilombolas}

The so-called Quilombas are settlements founded by runaway African slaves, brought to Brazil in the $17^{\text {th }}$ century. Slavery was abolished in 1888 , yet an estimated 22 Quilombas remain in Pará. Their inhabitants, known as Quilombolas, live of hunting, fishing, planting crops, and harvesting Brazil nuts, hence a lifestyle similar to many Caboclos. Quilombolas differ from many Caboclo settlements in that they are increasingly getting organized. ${ }^{3}$ Moreover, the state government facilitates this process via its Raizes Program. With the help of Raizes, amazing developments are taking place in some of the Quilombas. For example, Quilombolas communities have obtained titles to their land (12 tittles or 200,000 hectares) that has lead to further developments

\footnotetext{
${ }^{2}$ Most hunt with bows and arrows, often tipped with curare, a powerful muscle relaxant that kills the prey swiftly without harming the meat. Some tribes hunt birds and monkeys blow pipes up to 3 meters long. Even, today, many of the caboclos hunt small animals such as birds with slingshots.

${ }^{3}$ The constitution recognizes Indians right to own their land.
} 
of their community, such as the construction of a community-diven rural-agricultural school. $^{4}$

\section{Indigenous Peoples}

Before 1492, indigenous peoples numbered about 5-6 million in Brazil. During the five centuries after the arrival of the Europeans in Brazil, the indigenous population fell to around 100,000 in the 1950s. In 2000, there were around 215 tribes in Brazil, with a population of 350,000 , of which nearly two thirds live in the Amazon.

In Pará, there were around 214,000 Indians in 2000. They are present in 21 areas and each tribe has its own customs and most speak their own language. Some have very little contact with rest of the society and their small populations of a few dozen or less are extremely vulnerable. Others are increasing in size and have successfully campaigned for their land to be officially recognized and a few have own schools with instruction in their own language. They can live on and use certain areas of government-owned land, which have been recognized as "Indian areas". They have no ownership rights over their land. The territories of indigenous peoples, which cover about 20 percent of the Amazon and 26 percent of Pará, contain vast track of virtually undisturbed forest. However, as other parts of the Amazon are destroyed, these are suffering from increasing invasion and depletion by loggers, miners, and settlers.

The indigenous peoples have a profound knowledge of the natural world. Different parts of hundreds of plants are used for food and medicines, building canoes and houses, as well as for weaving hammocks, slings and baskets and making blow guns, darts, and bows and arrows. Plants are used for contraceptives, perfume, and soap, as well as for body painting and rituals.

\section{Migrants and other people}

The quest for higher standard of living continue and today's mining, logging, damming of rivers, cattle ranching, development of inappropriate forms of agriculture, and settlement projects may damage the environment including the great wildernesses in Pará. Clearance of huge, unproductive cattle ranches was, until recently, responsible for most of the deforestation. Moreover, colonization programs of the sort that accompanied the construction of the Transamazon Highway or BR364 contributed to massive forest loss and degradation. However, large-scale mining and industrial logging are now increasingly responsible for deforestation as the expanding road networks built by loggers attract colonists and ranchers, and facilitate access to the forest. Migrants from the Northeast and South of Brazil have flocked into the Amazon in hope of raising their standard of living. One of the first large migration inflows to Pará from the Northeast occurred between 1850-1910 and was mainly motivated by

\footnotetext{
${ }^{4}$ The school facilities are build and paid for by the local population, food and other necessities are paid for by the students and families, and so far, the developed is taking place with very little help from the government, except support for teachers salaries.
} 
rubber exploration (see below for migration patterns in the 1990's). For most settlers, life remains hard, faced with soils that cannot support crops, diseases, lack of infrastructure, and ranchers trying to take over their lands.

Others move to the North to mine. Gold miners (garimpeiros) have been working in the rainforests for decades, but the large gold rush began in 1980, when garimpeiros found a rich deposit in Serra Pelada. New industries in the Carajás region use charcoal made from trees, resulting in massive deforestation. Timber cutting is becoming the greater threat to the forests. Roads that the timber cutters build bring development to parts of the Amazon, which would otherwise have remained untouched. Only addressing the problems driving them, can stem the arrival of colonists. Without education, better distribution of wealth, land reform and technical assistance to small farmers, migrants may continue to arrive in the Amazon.

Some small farm communities have begun to devise the means of living in the forest sustainably. To help to conserve the minerals in the soil, these techniques involve the planting of perennial crops, such as trees, rather than annual crops, such as beans. This, not only protects the environment, but it also provides a steady source of income and is less labor intensive.

\section{DEMOGRAPHICS}

The degree of poverty a society might experience depends on the volume and distribution of resources and on the size and distribution of the population among households. These two basic determinants of poverty, however, are not independently determined. On one hand, the size and age structure of a population are consequences of fertility decisions taken over past decades that were influenced by economic conditions. On the other hand, the volume of resources available today is influenced by the size and age composition of the labor force. This section analyzes changes in macroeconomic stability, demography and employment in Pará in recent decades. The salient points are that macroeconomic stabilization has contributed to poverty reduction and demographic trends have been poverty reducing because they have lowered the dependency ratio, and this is likely to deepen further in the future. Demographic trends, which have lowered the dependency ratio, help explain the reduction in headcount poverty (see Section 4). ${ }^{5}$ This trend is likely to deepen further in the future as Brazil's richer regions, such as the Southeast, experience far lower fertility rates by age group than the North.

\footnotetext{
${ }^{5}$ Demographic factors have direct and indirect impacts on prices and poverty. As the size and age composition of the population changes, the relative size of the labor force and the number of dependents also change, modifying the dependency ratio of families, and therefore their level of poverty. This is the direct effect of demographic changes. It captures the effect that demographic changes have on quantities: number of children, size of the labor force, and the number of elderly people. These changes in quantities, however, will, in general, influence prices in the economy. In particular, changes in the rate of growth of the population and in the age structure may have important impacts on both labor supplies and savings. As a consequence, demographic changes may have considerable impact on the level of wages and on interest rates. Since these prices are important determinants of family income, they are bound to have a profound influence on the level of poverty. These are the indirect impacts of demographic changes on poverty, which occur through the effects of demographic changes on savings, wages, and interest rates.
} 
Pará's population is growing much faster than Brazil's population as a whole. During the last four decades, Pará's population has more than quadrupled. In 1960, Pará was home to 1.5 million people. In 2000, Pará's population has increased to 6.2 million (see Figure 2.1). After expanding at 3.5 percent per year between 1980 and 1991, Pará's population growth fell and its population increased by 2.5 percent per year during 1991-2000. In 2000, the population growth rate in Pará was lower than the North region as a whole (3.4 percent) but still higher than the national population growth rate of 2.0 percent. The rapid reduction in the population growth rate in Pará can be contributed to lower birth rates and a net migration outflow (see below). In Pará, the population growth was not equally distributed across the regions; Sudeste Paraense grew at 3.8 percent annually, while Baixo Amazonas grew at 2.3 percent annually (see also Section 4 on location, population, and poverty).

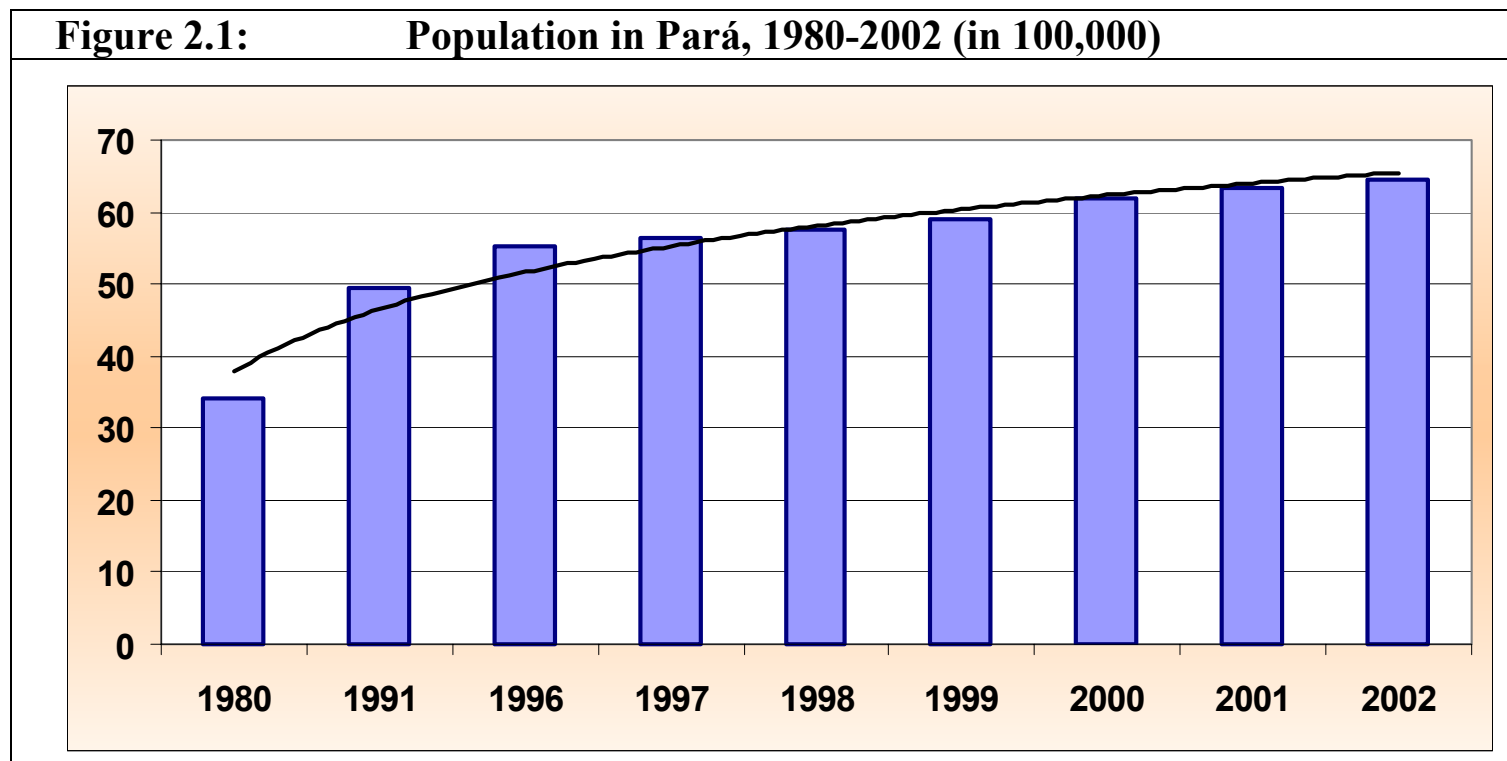

Source: SEPLAN / DIEEST/ BDE.

The North of Brazil continues being a net recipient of national migrants. During 19952002, the net inflow to the North region was around 33,000 people. The Center-West and Northeast of Brazil were the two largest sending regions, 16 and 13 percent respectively. However, the picture in Pará is different.

Pará experienced less migration inflow than most other states in Brazil during 19912000. In 2000, Pará moved down in the national ranking of the largest migrant, to a $14^{\text {th }}$ place, with around 4 percent of the population having lived less than 10 years in the state. This compares to a much higher figure, close to 10 percent, in 1991.

Pará has become a net-exporter of people during the 1990s. In Pará, the population growth rate is affected by the fact that more people left than arrived during 1991-2000. Pará received around 273,000 inhabitants from other states in Brazil and the vast majority (62 percent) arrived before 1998 (Table 2.3). In 1999, the number of inmigrants fell to slightly below 13,000 people annually. Out-migrants counted 370,000 people during 1991-2000 and the majority (65 percent) left before 1998 (Table 2.4). Hence, in Pará, the migration flows have been dramatically tamed in recent years and it 
has become a net-exporter of people, which together with a reduced fertility rate have reduced population growth.

Table 2.3:

In-migration to the North during 1991-2000

\begin{tabular}{|c|c|c|c|c|c|}
\hline \multirow{3}{*}{$\begin{array}{l}\text { Large Regions and } \\
\text { Federal Units }\end{array}$} & \multicolumn{5}{|c|}{ Non-native population of the with less than 10 continuous years of residence } \\
\hline & \multirow{2}{*}{$\begin{array}{c}\text { Total } \\
\text { (1) }\end{array}$} & \multicolumn{4}{|c|}{ Continuous time of residence } \\
\hline & & $\begin{array}{c}\text { Less than } 1 \\
\text { year }\end{array}$ & 1 to 2 years & 3 to 5 years & 6 to 9 years \\
\hline Brazil & 8463341 & 723480 & 2119545 & 2819157 & 2645904 \\
\hline North & 976169 & 77788 & 248074 & 319519 & 318817 \\
\hline Rondônia & 181479 & 16076 & 41948 & 60479 & 60942 \\
\hline Acre & 24471 & 3264 & 4170 & 8756 & 8097 \\
\hline Amazonas & 141580 & 8075 & 33225 & 61128 & 37160 \\
\hline Roraima & 81087 & 4042 & 23089 & 29988 & 23310 \\
\hline Pará & 272664 & 12531 & 89016 & 69465 & 96493 \\
\hline Amapá & 97854 & 8909 & 15774 & 40219 & 31946 \\
\hline Tocantins & 177034 & 24891 & 40853 & 49484 & 60868 \\
\hline
\end{tabular}

Table 2.4: $\quad$ Out-migration in the North during 1991-2000

\begin{tabular}{|c|c|c|c|c|c|}
\hline \multirow{3}{*}{ Previous residence } & \multicolumn{5}{|c|}{ Non-native population of the state with less than 10 years of residence } \\
\hline & \multirow[b]{2}{*}{ Total (1) } & \multicolumn{4}{|c|}{ Continuous time of residence } \\
\hline & & $\begin{array}{c}\text { Less than } 1 \\
\text { year }\end{array}$ & 1 to 2 years & 3 to 5 years & 6 to 9 years \\
\hline Brazil & 8463341 & 723480 & 2119545 & 2819157 & 2645904 \\
\hline North & 672718 & 55074 & 181268 & 239790 & 188971 \\
\hline Rondônia & 87403 & 8980 & 19901 & 24255 & 34267 \\
\hline Acre & 12647 & 752 & 4571 & 3099 & 4225 \\
\hline Amazonas & 82426 & 6081 & 18859 & 33112 & 20771 \\
\hline Roraima & 18943 & 1083 & 7936 & 7465 & 2459 \\
\hline Pará & 369493 & 27830 & 94247 & 138004 & 105616 \\
\hline Amapá & 19640 & 2676 & 8977 & 5480 & 2507 \\
\hline Tocantins & 82164 & 7671 & 26777 & 28375 & 19126 \\
\hline
\end{tabular}

Pará is becoming highly urbanized. In 1980 and 1991, Pará's population was more or less equally distributed between rural and urban areas (see Table 2.5). This contrasts the development in the 1990s where urban areas expanded rapidly. In 2000, 67 percent of the Paraenses lived in urban areas and more than half of the urban-dwellers lived in the state's six largest cities, each with more than 100,000 inhabitants (Belém, Ananindeua, Santarém, Marabá, Castanhal, and Abaetetuba). According to IBGE's definition of rural and urban areas, Pará is still far less urbanized than Brazil as a whole (where 81 percent lived in the urban areas in 2000 compared to 68 percent in 1980). But the urban population growth is increasing rapidly. In the 1970s, urban areas expanded at 5.0 percent annually, and during the 1990 s they reached 5.3 percent 
annually. This is in stark contrast with the population growth in rural areas that fell from 4.3 percent in the late 1970 s to 1.4 percent in the $1990 \mathrm{~s}$. Hence, this rapid expansion of the urban population has caused increased pressures on public services in urban areas.

\begin{tabular}{|lcc|}
\hline \multicolumn{2}{|c|}{$\begin{array}{c}\text { Table 2.5: } \\
\text { Residence }\end{array}$} & $\begin{array}{c}\text { Population Growth Rate per } \\
\text { An Pará, 1980/91/00 }\end{array}$ \\
\hline $\mathbf{3}$ & Urban & Rural \\
$\mathbf{1 9 8 0}$ & 49.0 & 51.01 \\
$\mathbf{2 0 0 0}$ & 53.0 & 47.6 \\
\hline Souce: SEOF/DIEED/BDE based on IBGE. & 33.5 \\
\hline
\end{tabular}

Pará is home to more males than females. The gender distribution in the North of Brazil, including Pará, shows that 51 percent of the resident populations are males compared to 49 percent in Brazil as a whole. This leads to a gender ratio of 1.02 percent that is slightly higher than in total Brazil (0.97 percent) and the ration increases to 116.5 in rural areas Metropolitan Belém is the only region that is home to more females than males in Pará (see Table 2.6). The share of female-headed households in total households is increasing rapidly in Pará as elsewhere in Brazil. In 2000, 22.6 percent of all households were female headed, up from 12.6 percent in 1980.

\begin{tabular}{|c|c|c|c|c|c|c|c|}
\hline Table 2.6: & opulation & $\begin{array}{l}\text { by Gr } \\
\text { 3y Me }\end{array}$ & $\begin{array}{l}\text { ender, } \\
\text { so Reg }\end{array}$ & $\begin{array}{l}\text { Reside } \\
\text { gions-I }\end{array}$ & $\begin{array}{l}\text { lence } \\
\text { Pará, }\end{array}$ & $\begin{array}{l}\text { Area, an } \\
, 2000\end{array}$ & \\
\hline Moso reqions & Residen & $\begin{array}{l}\text { Popula } \\
\text { Reside }\end{array}$ & $\begin{array}{l}\text { ation, } G \\
\text { nce Are }\end{array}$ & $\begin{array}{l}\text { ender a } \\
\text { a }\end{array}$ & and & Resident Po & ged 10 or Older \\
\hline & Total & Male & Female & Urban I & Rural & Total & Literacy \\
\hline Pará & 6192307 & 50.6 & 49.4 & 66.5 & 33.5 & 75.1 & 83.7 \\
\hline Baixo Amazonas & 10.3 & 51.2 & 48.8 & 56.3 & 43.7 & 72.8 & 84.8 \\
\hline Marajó & 6.1 & 52.1 & 47.9 & 38.8 & 61.2 & 68.4 & 68.0 \\
\hline Metropolitan Belém & 33.7 & 48.2 & 51.8 & 93.8 & 6.2 & 79.6 & 93.6 \\
\hline Northeast Pará & 23.8 & 51.7 & 48.3 & 47.4 & 52.6 & 72.4 & 76.7 \\
\hline Southeast Pará & 19.3 & 51.8 & 48.2 & 63.7 & 36.3 & 74.3 & 79.3 \\
\hline Southwest Pará & 6.9 & 53.0 & 47.0 & 47.3 & 52.7 & 74.4 & 78.4 \\
\hline
\end{tabular}

The share of children in the total population is falling. In 1980, children aged 14 and under accounted for 46 percent of the total population in Pará (Table 2.7). In 1991, the share of children aged 14 and under was down to 42 percent and in 2000 to 37 percent, slightly higher than in Brazil as whole (30 percent). This contrasts the development in the share of youth in the total population, which is increasing and in 2000, 22 percent of Pará's population were between 15 and 24 years of age. The number of elderly dependents has not caught up with the reduction in children's share in the population. In 2000 , only 3.9 percent of the population was 65 or older (Table 2.7 ). This will have a significant effect on the state's efforts to reduce poverty. For the next few decades, the 
ratio of children to working age population will decline, while the number of retirees will remain small. As a result, not only will dependency ratios fall, but also the amount the state must spend on expanding the quantity of social services will decline. This will free up resources to spend on improving quality and other poverty reduction efforts.

\begin{tabular}{|l|c|c|c|}
\hline \multicolumn{1}{|c|}{ Table 2.7: } & $\begin{array}{c}\text { Share of the Population per Age Group } \\
\text { Pará, 1980-2000 }\end{array}$ \\
\hline Age Group & $\mathbf{1 9 8 0}$ & $\mathbf{1 9 9 1}$ & $\mathbf{2 0 0 0}$ \\
\hline 0 - 6 years old & 23.29 & 21.73 & 17.64 \\
7 - 14 years old & 21.34 & 20.87 & 19.44 \\
15 - 64 years old & 52.19 & 54.22 & 59.07 \\
65years or older & 3.19 & 3.17 & 3.85 \\
Total & 100.00 & 100.00 & 100.00 \\
\hline \multicolumn{4}{|l}{} \\
\hline
\end{tabular}

Fecundity the number of children per mother dropped from 3.9 in 1992 to 3.1 in 1999 and is still among the six highest in Brazil. Women's increased participation in the labor market is an important factor contributing to the reduction in the fertility rate, which also produced a sharp drop in the dependency rate to 69.2 in 2000 compared to 94.4 in 1980 . However, fecundity did not fall for all age groups and fertility rates are much higher for the 15 to 19 and 20 to 24 age groups.

\section{Data and Methodology for Poverty Analyses}

This section presents some of the methodology and data used to analyze the poverty and quality of life in Pará, but does not attempt a more comprehensive quantitative and qualitative analysis of other forms of deprivation.

\section{METHODOLOGY}

The income-poverty measures are designed to count the poor and to diagnose the extent and distribution of poverty. The income-poverty measures proposed by Foster, Geer, and Thorbecke (1984) are used throughout the report. These are the headcount rate (P0), poverty gap (P1), and squared poverty gap (P2) measures. The former measures the magnitude of poverty and the latter two poverty measures assess both poverty magnitude and intensity.

The headcount rate is defined as the proportion of people below the poverty line. One concern applying the P0 measure is that each individual below the poverty line is weighted equally and, therefore, the principle of transfers is violated. Hence, it is possible to increase social welfare by transferring money from the very poor to lift some richer poor out of poverty. P0 takes no account of the degree of poverty and it is unaltered by policies that lead to the poor becoming even poorer.

One measure of poverty that takes this latter point into account (at least in weak form) is the poverty gap measures. P1 is the product of incidence and the average distance between the incomes of the poor and the poverty line. It can be interpreted as a per- 
capita measure of the total economic shortfall relative to the population. P1 distinguishes the poor from the not-so-poor and corresponds to the average distance to the poverty line of the poor. One problem with the poverty gap measure is that it will increase by transfers of money from poor to less poor (who become non-poor), and

from poor to non-poor. Furthermore, transfers among the poor have no effect on the poverty gap measure.

The P2 measure of poverty is sensitive to the distribution among the poor as more weight is given to the poorest below the poverty line. P2 corresponds to the squared average distance of income of the poor to the poverty line. Hence, moving from P0 towards $\mathrm{P} 2$, more weight is given to the poorest in the population.

This paper sets its poverty bar very low. To define "extreme poverty" it uses the indigence, or "food only" poverty line-those with sufficient income to buy a basic food basket are above the line. The poverty line is based on the monetary value of food items only. This measure is based on the cost of a "minimum food-basket" equal to the FAO minimum caloric intake of 2,288 daily per household member. Households are classified as extremely poor if their total income is less than the cost of a basic food basket. In 2001, the poverty line was of $\mathrm{R} \$ 80.92$. Finally, references are also made to the minimum wage and it was R\$151 in 2000.

As with most poverty studies in Brazil, no adjustment is made for the fact that young children do not need as many calories as adults do. Hence, the poverty rates presented in this paper may slightly overstate poverty in Pará.

The analysis of poverty correlates is based on two multivariate analyses, using the probit regression techniques, simultaneously for: (1) urban Brazil and urban Pará, and (2) urban and rural areas in Pará.

\section{DATA}

The analysis in this paper is based on available data: Brazilian household surveys PNADs (1981-2001), Censuses from 1991 and 2000, Indices of quality of life (IQV) from 1990 and 2000, human development Indicators (HDI) from 1991 and 2000, Contas Regionais do Brasil, Pesquisa Nacional de Saneamento Básico, and other data available online, such as educational data, including Bolsa Escola data, from MEC/INEP, government spending data from STN/Ministry of Finance and various data from the state government of Pará.

The PNADs for the North region, including Pará, contain information only on urban areas and has no information on rural areas. Therefore, to get a more adequate picture of poverty in Pará the micro data from the Census 2000 has also be applied to perform the analysis in this paper. The urban-rural distinction applied in Census 2000 data are not directly be comparable to earlier Census. For example, in the 1991 Census, a rural area was defined as an area with less than 5000 people, while in 2000 it was area with less than 10,000 inhabitants. All the income data applied in the analysis are spatially deflated by the deflators developed in Ferreira, Lanjouw, and Neri 1998 and timely deflated by the indicator for the month of the survey (the PNAD is undertaken in the month of September and the Census in the month of July). 


\section{Poverty, Income Inequality, and Quality of Life}

Growth is important, but is not the sole component of a poverty alleviation strategy. Programs are needed to ensure that the poor can take advantage of job opportunities and to protect some vulnerable groups that are not able to participate fully in the economy. In order to design these programs, information on the poor is needed. This section addresses headcount poverty and its depth, other poverty indicators, quality of life, human development, and inequality in Pará. Due to lack of data and information, this section does not address the broader issues of inequality of assets and opportunities.

In Pará, extreme poverty is high and counts 2.7 million people. Calculations based on micro data from the Census 2000 for both urban and rural poverty, reveal that the extreme poverty rate in Pará is still among the highest in Brazil. In 2000, the state's extreme poverty, measured by $\mathrm{P} 0$, is at 44 percent (Figure 4.1). This translates to over 2.7 million people who live in extreme poverty, which means that they do not have sufficient income to buy a minimum basket of food.

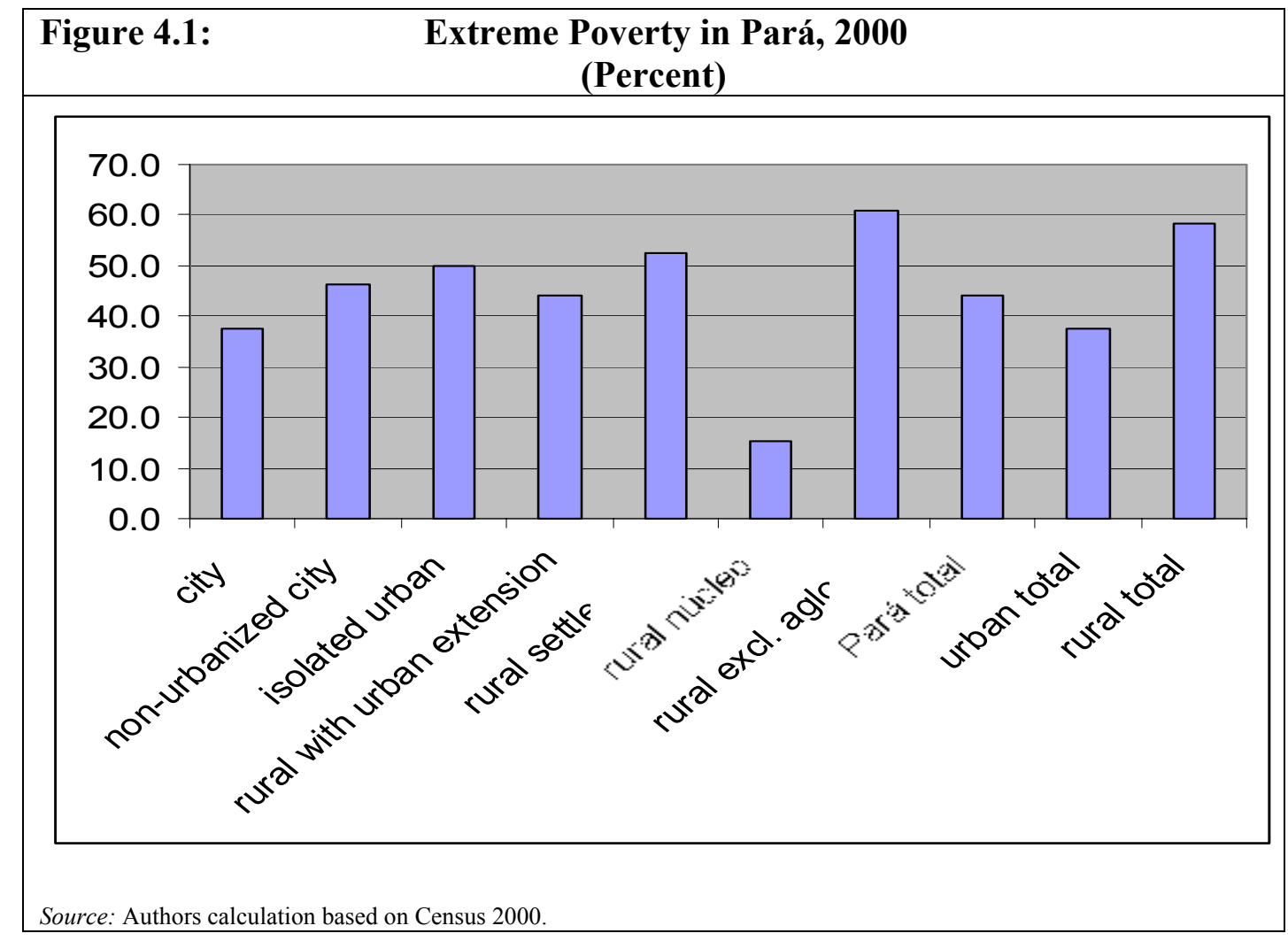

Extreme poverty differs highly between urban-rural sectors and sub-sectors. Figure 4.1 shows the differences in total urban and total rural poverty and difference across these two definitions. In 2000, the total income poverty rate in urban areas of 38 percent is below that of 58 percent in rural areas. However, Pará is highly urbanized, therefore more poor people live in urban areas than in rural areas. Analyzing the two sectors, it becomes clear that rural areas are not homogeneous in terms of extreme poverty. Calculations based on the Census 2000 data reveal that the rural poverty is lowest in rural settlements, with 5 percent of the population being below the poverty line, and it is 
lower than that of the rural-dwellers that are more spread-out (60 percent are poor). At this point it may be worth remembering that Pará is a rich state, with no semi-arid areas as in the Northeast region of Brazil, hence rural-dwellers have easier access to food items that possibility add calories to their daily diet, than urban-dwellers have. Therefore, the monetary poverty picture may not reflect adequately the poverty differences in rural and urban living. Unfortunately, no "environmental income" data are available in Brazil.

In the last decade Pará has made creditable headway in reducing urban poverty. Analyzes of poverty trends in urban Pará based on PNADs 1981-2001 reveal that during 1993-2001, the state's extreme urban poverty, measured by P0, fell 9 percentage points in urban areas and reached 33 percent in 2001 (Figure 4.2, Table 4.1, and Appendix B show urban poverty measured by P0, P1, and P2 for Brazil, and the state of Pará for 1981-2001). There is little room for complacency, however, because extreme poverty is still very high at 33 percent in urban areas. This translates to over 1.4 million people of the urban population ( 4.1 million) who still live in extreme poverty, which means that they do not have sufficient income to buy a minimum basket of food. This is a poverty rate more than 50 percent higher than that of urban areas in Brazil (22 percent) and 10 percent higher than that of urban areas in the North as a whole (30 percent), see Table 4.1 .

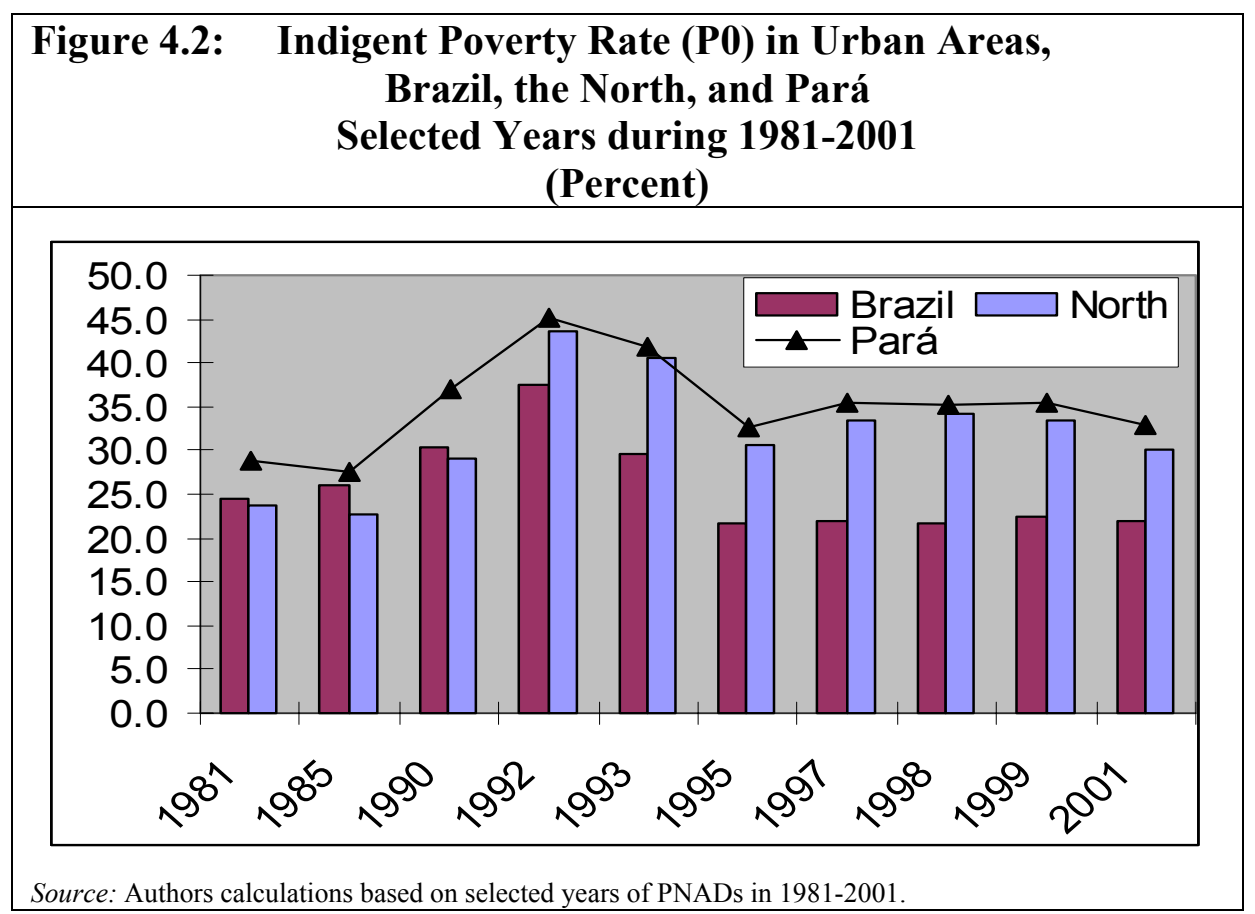

Urban poverty did not fall monotonically over the last two decades. The P0 increased from 29 per cent in the beginning of the 1980s, increased before the federal government's implementation of the inflation-beating Cruzado Plan of 1986, increased when the plan collapsed, and increased even more during the crisis of 1990 where it hit an all-time high of 45 percent urban poverty rate (Figure 4.2). The P0 embarked on a downward path only after the most recent inflation-beating Real Plan of 1994 was implemented and the minimum wage increased. There was a sharp decline in poverty 
to a level lower than at any point during the previous decade, except 1981. After the Real Plan was implemented, the P0 for urban areas fell 8 percentage points in Brazil and 11 percentage points in the North. Pará managed to reduce the P0 by 9 percentage points, which is in line with reduction in the national rate. Since 1996, poverty increased slightly and stabilized at around 35 percent at the end of the 1990s. During 1999-2001 urban poverty fell, slightly and reached 33 percent in 2001.

\begin{tabular}{|l|ccc|c|}
\hline Table 4.1: & P0, P1, P2 and Mean Income in Urban Areas - 2001 \\
\hline & P0 & P1 & P2 & $\begin{array}{c}\text { Mean Per Capita Income } \\
\text { (Monthly R\$) }\end{array}$ \\
\hline Brazil & & & & 341.1 \\
São Paulo & 18.5 & 9.4 & 6.8 & 454.0 \\
Northeast & 8.8 & 5.2 & 4.3 & 182.9 \\
North & 37.0 & 18.6 & 12.7 & 206.3 \\
Rondônia & 30.1 & 14.5 & 10.0 & 223.6 \\
Acre & 24.7 & 11.3 & 7.7 & 283.3 \\
Amazonas & 28.6 & 15.0 & 10.8 & 207.7 \\
Roraima & 32.9 & 16.6 & 11.9 & 223.9 \\
Pará & 24.7 & 12.9 & 9.5 & 183.8 \\
Amapá & 33.0 & 15.6 & 10.6 & 260.0 \\
Tocantins & 12.2 & 6.9 & 5.5 & 226.6 \\
\hline Source: Calculations based on PNAD 2001. & 26.4 & 11.8 & 7.7 & \multicolumn{4}{l}{} \\
\hline
\end{tabular}

In the last decade most of the reduction in poverty in Brazil, including in Pará can be credited to national economic policies. Brazil's macroeconomic stabilization, including the devaluation of the real, was clearly the most important poverty-reducing factor in the 1990s. Increased trade, opening the economy to foreign investment, an increase in the minimum wage, and increased access to social services and assistance have also played important parts.

Only the most recent of the six stabilization plans since 1985, the Real Plan of July 1994, achieved macroeconomic stability and reduced inflation to a record single-digit low. ${ }^{6}$ The poor generally suffer most from high inflation, partly because they cannot protect themselves against it because they lack access to the financial and banking systems. So, policies that reduce inflation commonly enhance their incomes. This applies to the poor in Pará and elsewhere. Differences in inflation among the regions of Brazil are minuscule and cannot be the sole determinant of regional differences in poverty, but inflation does affect the overall poverty trend. In May 1995 the minimum wage was raised while monthly inflation was about 2 percent, which may have reduced poverty.

The fall in Pará's social indicators, such as infant mortality corroborates the improvement in measured urban income poverty. The infant mortality rate (IMR) dropped dramatically from 73.6 per 1,000 live births in 1980 to 34.6 per 1,000 live

\footnotetext{
${ }^{6}$ The Real Plan of 1994 (1) introduced an exchange rate anchor with flexibility to move within a band, (2) de-indexed the economy, and (3) implemented tight credit and monetary policies.
} 
births in 1999 (Table 4.2). In 1999, the infant mortality rate was in line with the average for Brazil. However, the infant mortality rate in Pará is still much higher than in the South of the country, for example in Rio Grande do Sul infant mortality reached 18.4 percent of live born infants.

Advances in infant mortality reduction can be attributed to increase service delivery. The large advances in reducing the IMR that took place in Pará can be attributed to an improved health care system, increased access to treated water, economic growth, urbanization, and past investments in education, and other social programs. Hence, to further reduce the infant mortality rate in order to reach the national average of 35 percent, especially in the rural areas, further actions are called for. These include general livelihood improvements such as access to clean water and sanitation, high quality education and health care, and a daily caloric intake sufficient to cover the basic needs. Moreover, research shows that a 10 percent increase in income is associated with a 6 percent lower infant mortality rate (Filmer and Pritchett, 1997).

\begin{tabular}{|c|c|c|c|c|}
\hline \multirow{2}{*}{\begin{tabular}{|l|} 
Table 4.2: \\
Region/State
\end{tabular}} & \multicolumn{4}{|c|}{ Infant Mortality, 1970-99 } \\
\hline & 1970 & 1980 & 1991 & 1999 \\
\hline \multirow{5}{*}{$\begin{array}{l}\text { North } \\
\text { Rondônia } \\
\text { Acre } \\
\text { Amazonas } \\
\text { Roraima }\end{array}$} & 113.3 & 71.1 & 51.0 & 34.1 \\
\hline & 156.1 & 76.8 & 47.1 & 31.6 \\
\hline & 120.7 & 78.4 & 60.6 & 44.2 \\
\hline & 112.1 & 62.2 & 45.4 & 31.8 \\
\hline & 113.3 & 71.1 & 51.0 & 38.3 \\
\hline \multirow{3}{*}{$\begin{array}{l}\text { Pará } \\
\text { Amapá } \\
\text { Tocantins }\end{array}$} & 110.8 & 73.6 & 52.6 & 34.6 \\
\hline & 113.3 & 71.1 & 51.0 & 31.7 \\
\hline & 90.1 & 62.3 & 54.2 & 33.0 \\
\hline \multirow{2}{*}{$\begin{array}{l}\text { Nordeast } \\
\text { Sudeast }\end{array}$} & 179.2 & 131.3 & 82.5 & 53.0 \\
\hline & 94.0 & 63.4 & 32.2 & 24.4 \\
\hline South & 84.0 & 54.1 & 29.0 & 20.7 \\
\hline \multirow{4}{*}{$\begin{array}{l}\text { Paraná } \\
\text { Santa Catarina } \\
\text { Rio Grande do Sul }\end{array}$} & 98.6 & 65.6 & 35.6 & 24.3 \\
\hline & 85.4 & 55.6 & 28.8 & 22.2 \\
\hline & 62.8 & 40.0 & 22.3 & 18.4 \\
\hline & 94.9 & 59.3 & 32.5 & 24.5 \\
\hline $\begin{array}{l}\text { Center-West } \\
\text { Brazil }\end{array}$ & 123.2 & 85.2 & 49.5 & 34.6 \\
\hline
\end{tabular}

Across the regions, large differences exist in infant mortality. In 2000, the infant mortality rate was lowest in the Metropolitan region (26.8) and Almeirim (22.6) (Table 4.3). This is mainly due to the easy access to hospital, prenatal care, education, clean water, etc. in these cities. In more remote and poorer areas where many services are lacking or difficult to access, such as Marabá and Paráuapebas, the IMR was nearly double that of the Metropolitan region in 2000.

The adult illiteracy rate took the same declining path as headcount poverty and infant mortality. In Pará, during 1991-2000, the illiteracy rate for people over age 15 fell 8.9 
percent, to 17 percent in 2000. However, Pará is still among the 11 states with the highest illiteracy rate in Brazil. Efforts to lower illiteracy even further are hampered by the fact that many of the illiterates are adult — the result of years of educational neglect. Efforts to improve adult literacy have been undertaken, but with poor results, because it is more difficult to teach basic skills to adults than to children.

\begin{tabular}{|l|ccc|}
\hline Table 4.3: & \multicolumn{4}{c|}{ Infant Mortality } & Rate in Pará, 1990-2000 \\
\hline Micro regions & $\mathbf{1 9 9 0}$ & $\mathbf{1 9 9 4}$ & $\mathbf{2 0 0 0 *}$ \\
\hline State of Pará & $\mathbf{4 8 . 1}$ & $\mathbf{3 8 . 7}$ & $\mathbf{3 4 . 9}$ \\
Almeirim & 30.1 & 24.3 & 22.6 \\
Altamira & 41.2 & 34.1 & 32.5 \\
Arari & 40.4 & 34.7 & 31.9 \\
Belém & 32.5 & 28.4 & 26.8 \\
Bragantina & 61.7 & 52.3 & 49.2 \\
Cametá & 40.8 & 35.2 & 31.7 \\
Castañal & 42.7 & 36.7 & 34.8 \\
Conc.Araguaia & 52.9 & 41.5 & 40.1 \\
Furos de Breves & 35.3 & 29.8 & 28.4 \\
Guamá & 61.6 & 54.7 & 50.6 \\
Itaituba & 72.1 & 60.4 & 54.5 \\
Marabá & 69 & 60.3 & 59.2 \\
Óbidos & 47.5 & 39.6 & 35.4 \\
Paragominas & 68.8 & 59.5 & 56.9 \\
Parauapebas & 71.6 & 59.5 & 58.1 \\
Portel & 62.4 & 57.8 & 56 \\
Redenção & 52.3 & 45.5 & 44.6 \\
S.Félix Xingu & 47.6 & 39.5 & 38.2 \\
Salgado & 48.8 & 42.5 & 39.8 \\
Santarém & 58 & 47.1 & 43.4 \\
Tomé-Açu & 36.7 & 31.8 & 29.6 \\
Tucuruí & 49.8 & 41.6 & 39.5 \\
\hline Source: SEOF/DIEEST/BDE based on Ministério da Saúde/DATASUS and "Indicadores \\
e Dados Básicos". & & & \\
*) Calculations by Health Ministry in the publication " Indicadores e Dados Básicos". & \\
\hline
\end{tabular}

Illiteracy has a spatial dimension and it is not uniform across regions. Marajó and Southwest Pará, the two most sparsely populated regions and that are highly rural, have the highest rates of illiteracy in the state, 32 percent and 22 percent, respectively. This compares to the low illiteracy rate of 6 percent in the Metropolitan region of Belém. 


\begin{tabular}{|c|c|c|c|}
\hline Table 4.4: & Adul & & \\
\hline Region/State & 1991 & 2000 & $\begin{array}{c}\text { 1991-2000 } \\
\text { Change }\end{array}$ \\
\hline North & 75.9 & 83.7 & 10.2 \\
\hline Rondônia & 80.4 & 87.0 & 8.2 \\
\hline Acre & 65.7 & 75.5 & 14.9 \\
\hline Amazonas & 76.2 & 84.5 & 10.9 \\
\hline Roraima & 78.3 & 86.5 & 10.5 \\
\hline Pará & 76.4 & 83.2 & 8.9 \\
\hline Amapá & 80.7 & 87.9 & 8.9 \\
\hline Tocantins & 69.9 & 81.2 & 16.2 \\
\hline Northeast & 63.5 & 73.8 & 16.2 \\
\hline Southeast & 88.2 & 91.9 & 4.2 \\
\hline South & 88.7 & 92.3 & 4.1 \\
\hline Mid-West & 83.9 & 89.2 & 6.4 \\
\hline Brazil & 80.6 & 86.4 & 7.2 \\
\hline
\end{tabular}

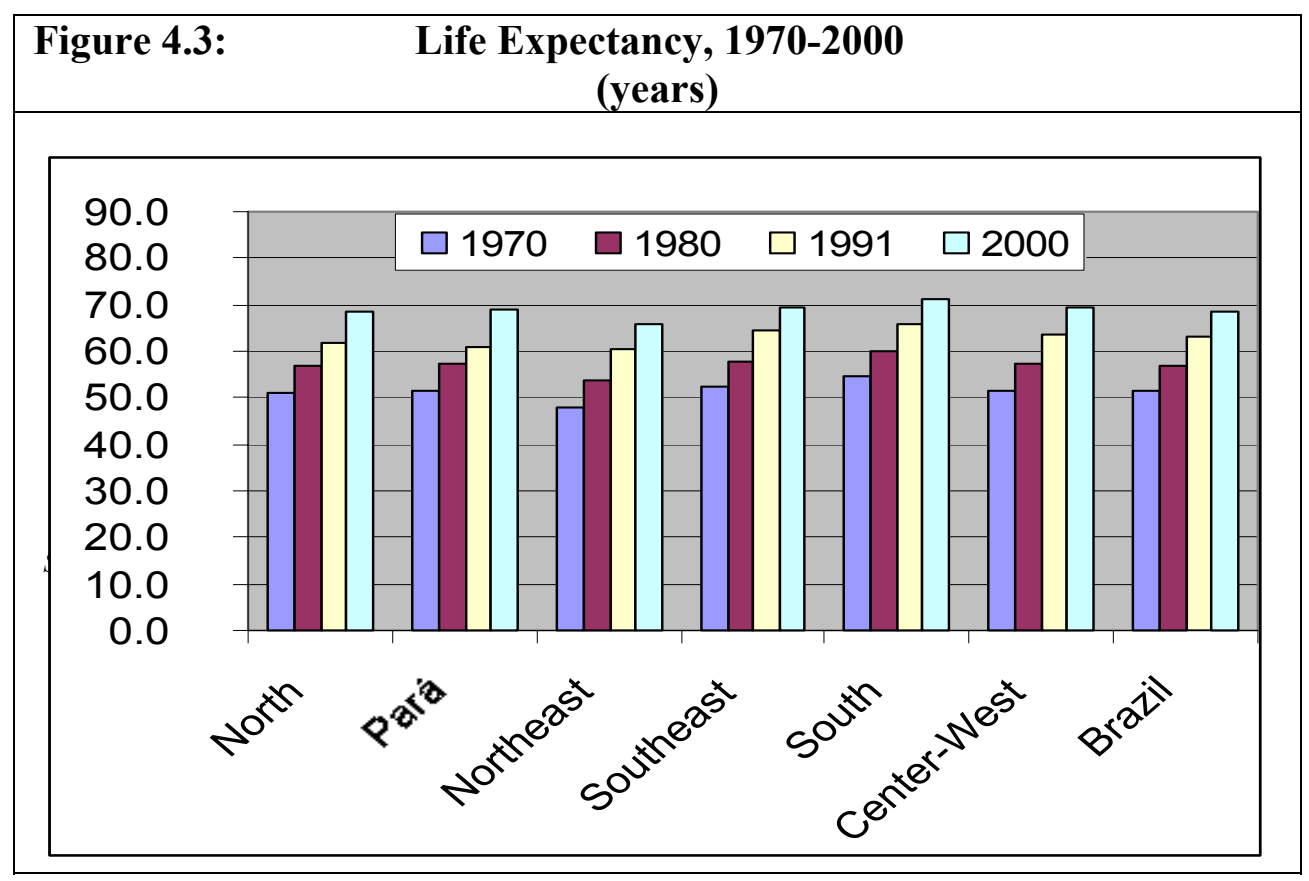

The increase of Pará's life expectancy corroborates the improvement in monetary and non-monetary indicators. In Pará, life expectancy reached 69 years in 2000. Pará's life expectancy at birth increased 34 percent or 17 years, the same as in the North region as a whole, during 1970-2000 (see Figure 4.3). There exits a gender differential in life expectancy. Men in Pará, as in many parts of Brazil, have significantly lower life expectancy than women. 


\section{LOCATION AND POVERTY}

In Pará, the population growth experienced in the last decades is far from homogeneous throughout the state (see also Section 4.5). The large regional differences within the state are associated with the expansion of economic activities and population inflow into a few areas. Of the 21 micro regions in Pará, 12 experienced an above-average expansion of population during 1991-2000 (see Table 4.5).

\begin{tabular}{|c|c|c|c|c|c|c|c|c|c|c|c|}
\hline \multirow{3}{*}{\begin{tabular}{|r|} 
Table 4.5 \\
\\
Micro Region
\end{tabular}} & \multicolumn{11}{|c|}{$\begin{array}{l}\text { Population and Poverty per Micro Region in Pará } \\
\qquad 1980-2000\end{array}$} \\
\hline & \multicolumn{5}{|c|}{ Population } & \multicolumn{3}{|c|}{$\begin{array}{l}\text { Family income per } \\
\text { capita }(\mathrm{R} \$ / \text { month) }\end{array}$} & \multicolumn{3}{|c|}{$\begin{array}{l}\text { Household heads with } \\
\text { income }<1 \text { Min Salary }\end{array}$} \\
\hline & 1980 & 1991 & 2000 & $\begin{array}{l}\text { Growth } \\
1980-00\end{array}$ & $\begin{array}{l}\text { Growth } \\
1991-00 \\
\end{array}$ & 1991 & 2000 & $\begin{array}{l}\text { Growth } \\
1991-00\end{array}$ & 1991 & 2000 & $\begin{array}{l}\text { Growth } \\
1991-00\end{array}$ \\
\hline Pará & $3,403,391$ & $4,950,060$ & $6,192,307$ & 3.0 & 2.5 & 252 & 317 & 2.6 & 238,640 & 280,314 & 17.5 \\
\hline Almeirim & 44,889 & 48,849 & 57,502 & 1.2 & 1.8 & 290 & 400 & 3.6 & 1,798 & 2,276 & 26.6 \\
\hline Altamira & 52,817 & 197,262 & 226,370 & 7.5 & 1.5 & 277 & 337 & 2.2 & 9,727 & 7,670 & -21.1 \\
\hline Arari & 77,780 & 90,411 & 117,279 & 2.1 & 2.9 & 168 & 214 & 2.7 & 6,442 & 8,357 & 29.7 \\
\hline Belém & $1,041,507$ & $1,447,251$ & $1,858,804$ & 2.9 & 2.8 & 538 & 471 & -1.5 & 43,545 & 61,579 & 41.4 \\
\hline Bragantina & 256,362 & 281,053 & 329,184 & 1.3 & 1.8 & 184 & 189 & 0.3 & 20,002 & 22,341 & 11.7 \\
\hline Cametá & 248,400 & 300,854 & 353,860 & 1.8 & 1.8 & 160 & 156 & -0.3 & 17,824 & 20,950 & 17.5 \\
\hline Castañal & 134,072 & 173,313 & 226,271 & 2.7 & 3.0 & 267 & 240 & -1.2 & 9,103 & 10,931 & 20.1 \\
\hline Conceição do Araguaia & 124,173 & 78,051 & 99,843 & -1.1 & 2.8 & 240 & 233 & -0.4 & 4,564 & 5,393 & 18.2 \\
\hline Furos de Breves & 116,170 & 136,562 & 165,665 & 1.8 & 2.2 & 168 & 156 & -0.8 & 6,812 & 7,708 & 13.2 \\
\hline Guamá & 274,728 & 309,008 & 363,059 & 1.4 & 1.8 & 155 & 161 & 0.5 & 18,208 & 22,562 & 23.9 \\
\hline Itaituba & 51,329 & 146,746 & 197,942 & 7.0 & 3.4 & 319 & 311 & -0.3 & 7,387 & 7,323 & -0.9 \\
\hline Marabá & 95,687 & 155,431 & 215,280 & 4.1 & 3.7 & 265 & 308 & 1.7 & 9,051 & 10,204 & 12.7 \\
\hline Óbidos & 102,791 & 120,297 & 150,649 & 1.9 & 2.5 & 195 & 174 & -1.2 & 7,477 & 9,766 & 30.6 \\
\hline Paragominas & 48,109 & 148,268 & 216,851 & 7.8 & 4.3 & 279 & 295 & 0.6 & 5,490 & 8,289 & 51.0 \\
\hline Parauapebas & 0 & 92,007 & 153,668 & - & 5.9 & 332 & 320 & -0.4 & 4,035 & 5,670 & 40.5 \\
\hline Portel & 77,616 & 76,803 & 95,913 & 1.1 & 2.5 & 139 & 137 & -0.2 & 3,792 & 4,408 & 16.2 \\
\hline Redenção & 0 & 169,068 & 167,206 & - & -0.1 & 282 & 333 & 1.9 & 8,360 & 6,808 & -18.6 \\
\hline Salgado & 136,350 & 184,580 & 215,774 & 2.3 & 1.8 & 151 & 206 & 3.5 & 13,531 & 13,430 & -0.7 \\
\hline Santarém & 319,746 & 391,651 & 430,169 & 1.5 & 1.0 & 204 & 227 & 1.2 & 22,998 & 22,851 & -0.6 \\
\hline São Félix do Xingu & 4,982 & 84,984 & 89,159 & 15.5 & 0.5 & 474 & 391 & -2.1 & 3,004 & 2,333 & -22.3 \\
\hline Tomé-Açu & 104,234 & 155,965 & 211,731 & 3.6 & 3.5 & 222 & 211 & -0.6 & 7,100 & 8,283 & 16.7 \\
\hline Tucuruí & 91,649 & 161,646 & 250,128 & 5.1 & 5.0 & 227 & 263 & 1.7 & 8,390 & 11,182 & 33.3 \\
\hline
\end{tabular}

Heads of households with earnings less than one minimum salary increased 14 percent during 1991-2000. Despite migration in search for opportunities, and not least income, poverty remained rampant and even increased in the fast growing regions. The regions that experienced the fastest population growth also experienced the fastest growth in family heads with low income, that is with an income less than one minimum salary during 1991-2000. In this period, the household heads with low income increased by 41,000 and reached more than 280,000 in 2000 (see Table 4.5). 
Belém region hosts the most and has the fastest growth of poor headsof households. The share of household heads earning less than one minimum salary also varies across regions. The Belém region is the region with the largest number of poor heads of households, 22 percent of the 280,314 total in Pará. Bragantina, Guamá, and Santarém each host around 8 percent of household heads with income less than one minimum salary (Table 4.5). Only the latter experienced negative growth in the number of poor, while the former two regions, poverty increased by 12 and 24 percent respectively. Hence, these numbers show that poverty in Pará is highly urban and, therefore, not only a rural phenomenon.

\section{POVERTY DEPTH}

Although Pará has made substantial progress in reducing the share of the population living in extreme poverty, the problem remains broad and deep. The $\mathrm{P} 0$, analyzed above, measures the proportion of people below a certain poverty line but takes no account of how far they are below that line - the degree of poverty - or whether they are becoming even poorer. To address the situation of the poorest and to evaluate whether their economic situation has improved, the squared poverty gap measure is used. This takes into account the degree of poverty, because it gives more weight to the poorest and most vulnerable.

Poverty is deep in Pará. The squared poverty gap measure (P2) reveals that the extreme income poverty in Pará reached 15.7 percent in 2000. Poverty was deepest in rural areas, where P2 reached 24.7 percent compared to 11.6 percent in urban areas in 2000.

The depth of urban poverty increased since 1995. P2 reveals that the extreme poverty in Pará's urban areas fell 26 percent to 9.3 percent during 1993-1995 (Figure 4.4). During 1995-2001, the trend reversed and P2 increased by 14 percent in Pará to 10.3 percent in 2001, while the Amazon region as a whole only experience an increase of 8.5 percent in the depth of urban poverty. In 2001, the depth of urban poverty in Pará was one and three percentage points higher then in the Amazon region and Brazil as a whole. As a matter of fact, P2 reveals that urban poverty was much deeper in 2001 than in 1981 (122 percent), implying that the poorest became much poorer during the past two decades. In fact, Pará has performed worse than Brazil as a whole where P2 increased by 52 percent. 


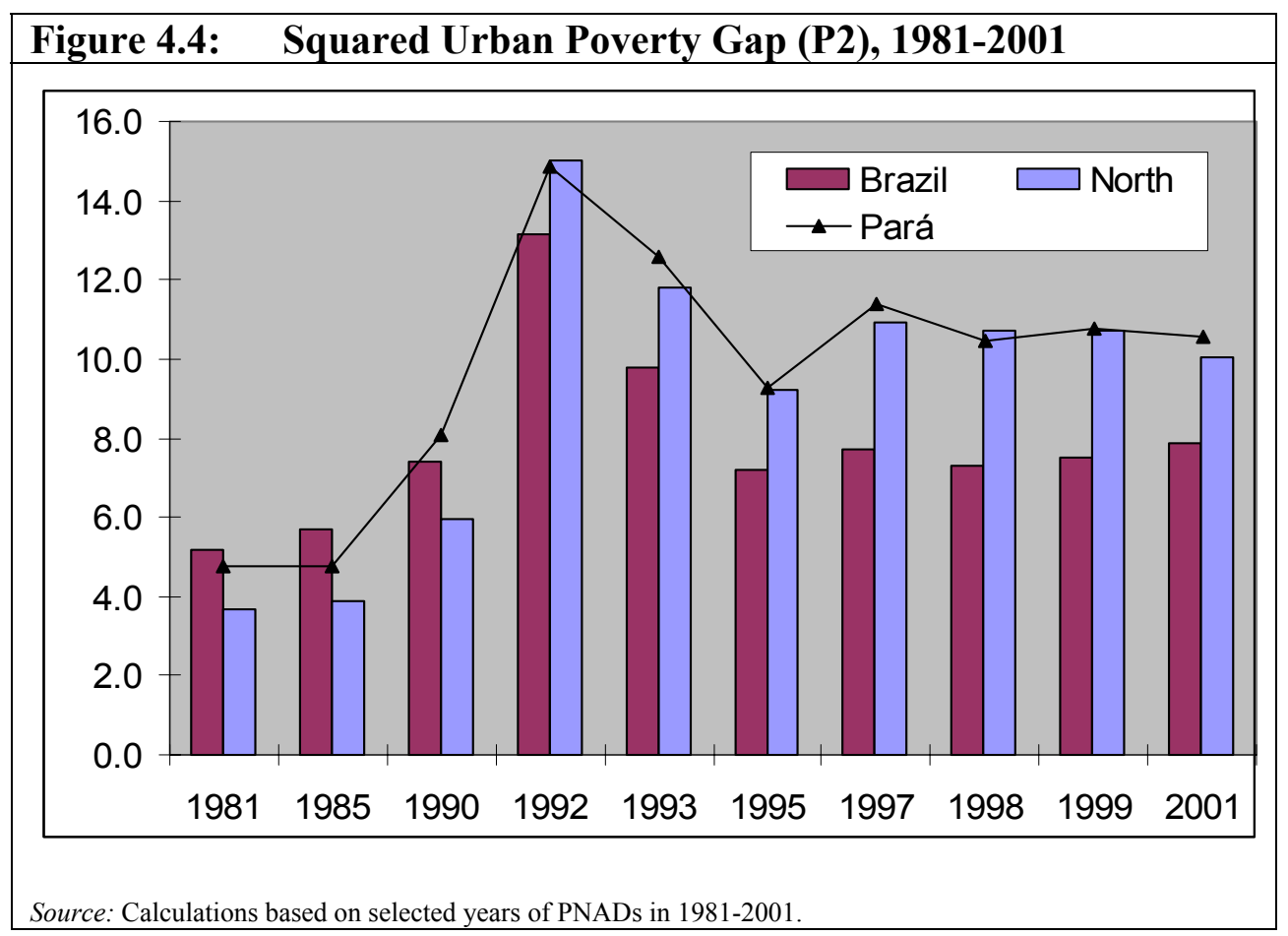

The income of the extreme poor is stagnant. One possible explanation for the recent increase in the depth of poverty could be the drop in average incomes of the extreme poor. Data for 1995-2001 reveal that after the launch of the inflation-beating Real Plan in 1994 average per-capita household incomes fell in urban areas in Brazil and in the northern states, including Pará (see Table 4.6). In 2000, the average per-capita income of the extreme poor urban household heads of $\mathrm{R} \$ 34$ was less than a fourth of the mean income of the non-poor in Pará. Furthermore, the average per-capita household income of the extreme poor in urban areas fell marginally more in Pará than in other states in the Amazon region and in Brazil as a whole.

\begin{tabular}{|c|c|c|c|c|c|}
\hline \multicolumn{6}{|c|}{$\begin{array}{l}\text { Table 4.5: Mean Income of the Extreme Poor in } \\
\text { Urban Areas, Selected Years 1995-2001 (R\$) }\end{array}$} \\
\hline & 1995 & 1997 & 1998 & 1999 & 2001 \\
\hline Brazil & 33.4 & 32.4 & 33.1 & 33.7 & 31.9 \\
\hline North & 35.5 & 34.2 & 35.0 & 34.6 & 33.7 \\
\hline Rondônia & 37.0 & 38.0 & 39.3 & 31.4 & 35.1 \\
\hline Acre & 33.1 & 27.2 & 34.7 & 33.5 & 30.9 \\
\hline Amazonas & 34.4 & 34.6 & 33.3 & 34.3 & 32.2 \\
\hline Roraima & 32.1 & 42.2 & 36.6 & 31.5 & 31.0 \\
\hline Pará & 36.8 & 34.4 & 36.1 & 35.7 & 34.3 \\
\hline Amapá & 37.1 & 30.9 & 29.8 & 32.0 & 28.6 \\
\hline Tocantins & 33.7 & 33.8 & 34.8 & 35.0 & 35.9 \\
\hline
\end{tabular}




\section{QUALITY OF LIFE AND HUMAN DEVELOPMENT}

This section presents an analysis of the quality of life and human development in Pará. The quality of life index (indice de qualidade de vida-IQV) is a composite index containing 21 indicators of socio-economic well-being related to outcomes in sectors, such as education, health, and water supply developed by IPLANCE. The length of the bar in Figure 4.5 indicates the advance made in the state during 1991-1999. Hence, the bottom of the bar shows the IQV in 1991 and the top the IQV in 1999. Great advances have occurred throughout the period and the poorest states have made much greater advances than rich states in Brazil.

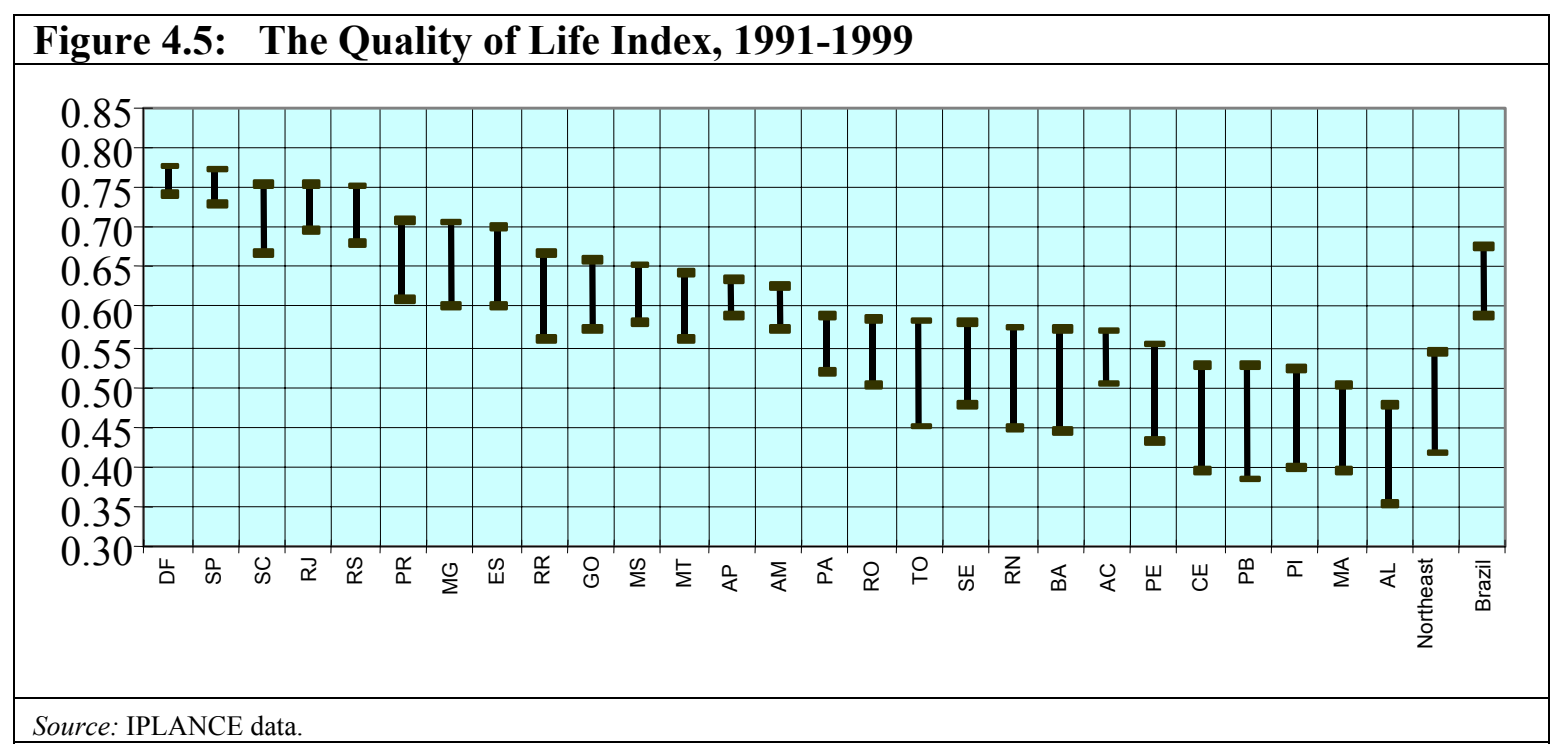

The quality of life improved in the Amazon during the 1990s. Pará experienced an increase of 13.5 percent in IQV, slightly below the improvement in the quality of life in Brazil as a whole (14.7 percent) and the North region (14.6 percent). However, Pará improved less than other states in the region, such as Tocantins (Figure 4.6). This indicates that a possible catch-up effect in the quality of life is not at play for all states in Brazil.

The Human Development Index (HDI) reveals general improvement has taken place in Pará but at a slightly slower pace than in other states. Figure 4.7 and Table 4.6a reveal that Pará's human development indicator of 0.72 is slightly below the Brazil average of 0.76 in 2000. In 2000, Pará placed 0.12 points below Brasilia that has the biggest HDI in Brazil, and 0.9 points above Alagoas, the state with the lowest HDI. Furthermore, Pará has advanced less rapidly than other states during 1991-2000. The average Brazilian growth rate of the HDI was 10.9 percent and Pará advance less (8.2 percent) in the same period. In 1991, Pará was placed number 16 in the Brazilian ranking of HDI and during the 90 's it dropped one place in the ranking reaching the $17^{\text {th }}$ place of the 27 states. 

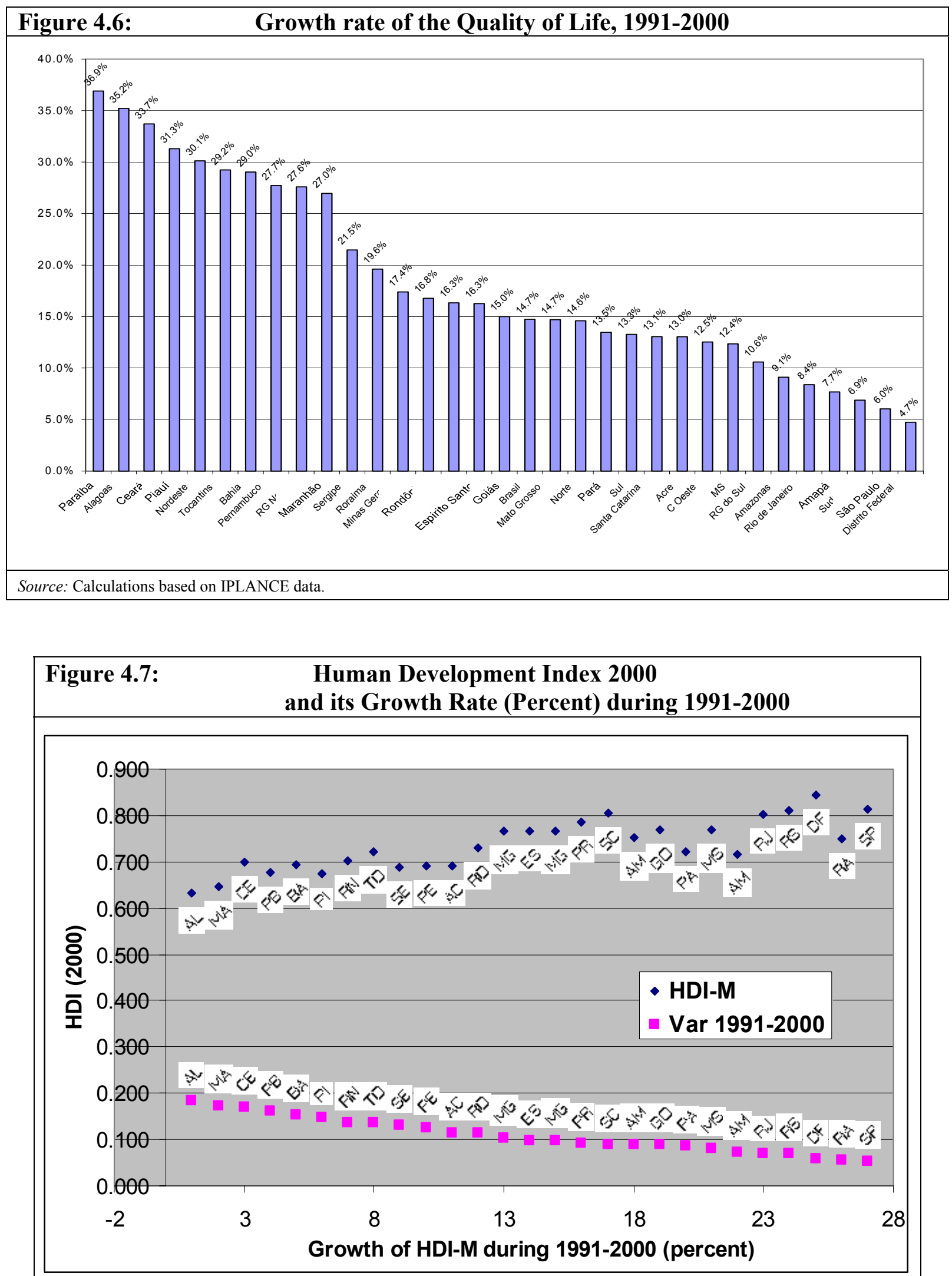

Source: Calculations based on UNDP data 
Pará's low HDI performance is mainly caused by lack of income. Disaggregating the HDI reveals that Pará is performing relatively well in education and health, while income generation shows difficulties. Education improved 15 percent during 1991-2000 and reached 0.81 in 2000 (see Table 4.6a). This placed Pará sixteenth in the educational ranking. In health, measured by life expectancy at birth, Pará ranked higher (number 12) and increased by 5.8 percent during 1991-2000 and reached 0.72 in 2000, only 0.05 points below Rio Grande do Sul that ranks number one (Table 4.6b). In income, Pará ranked twentieth, down from a seventeenth place in 1991. Income in Pará only increased 4.6 percent in the 1990s (Table 4.6b). The seven states below Pará in the raking, all started from a very low initial and experienced income growth rates double or triple that of Pará.

\begin{tabular}{|c|c|c|c|c|c|}
\hline Table 4.6a: & $\begin{array}{r}\text { ducatio } \\
1991 \\
\end{array}$ & $\begin{array}{l}n \\
1-2000\end{array}$ & & & \\
\hline & ndex- & & $\begin{array}{r}\text { HD } \\
\text { Edu }\end{array}$ & $\begin{array}{l}\text { DI-M } \\
\text { ucatio }\end{array}$ & \\
\hline & & Growth (\%) & & & Growth (\%) \\
\hline & 2000 & $1991-2000$ & & 2000 & 1991-2000 \\
\hline Distrito Federal & 0.844 & 5.9 & Distrito Federal & 0.935 & 8.3 \\
\hline São Paulo & 0.814 & 5.3 & Santa Catarina & 0.906 & 12.1 \\
\hline Rio Grande do Sul & 0.809 & 6.9 & Rio Grande do Sul & 0.904 & 9.4 \\
\hline Santa Catarina & 0.806 & 8.9 & Rio de Janeiro & 0.902 & 7.7 \\
\hline Rio de Janeiro & 0.802 & 6.9 & São Paulo & 0.901 & 7.6 \\
\hline Paraná & 0.786 & 9.3 & Amapá & 0.881 & 16.6 \\
\hline Goiás & 0.770 & 8.8 & Paraná & 0.879 & 13.0 \\
\hline Mato Grosso do Sul & 0.769 & 8.0 & Goiás & 0.866 & 13.2 \\
\hline Mato Grosso & 0.767 & 10.2 & Roraima & 0.865 & 15.3 \\
\hline Espírito Santo & 0.767 & 9.8 & Mato Grosso do Sul & 0.864 & 11.8 \\
\hline Minas Gerais & 0.766 & 9.7 & Mato Grosso & 0.860 & 16.0 \\
\hline Amapá & 0.751 & 8.8 & Espírito Santo & 0.855 & 11.9 \\
\hline Roraima & 0.749 & 5.5 & Minas Gerais & 0.850 & 13.2 \\
\hline Rondonia & 0.729 & 11.3 & Rondonia & 0.832 & 14.9 \\
\hline Tocantins & 0.721 & 13.6 & Tocantins & 0.827 & 24.1 \\
\hline Pará & 0.720 & 8.6 & Pará & 0.815 & 14.8 \\
\hline Amazonas & 0.717 & 7.3 & Amazonas & 0.813 & 14.9 \\
\hline Rio Grande do Norte & 0.702 & 13.6 & Bahia & 0.785 & 27.6 \\
\hline Ceará & 0.699 & 17.0 & Rio Grande do Norte & 0.779 & 21.4 \\
\hline Bahia & 0.693 & 15.3 & Ceará & 0.772 & 27.9 \\
\hline Acre & 0.692 & 11.6 & Sergipe & 0.771 & 22.3 \\
\hline Pará & 0.692 & 12.6 & Pará & 0.768 & 19.3 \\
\hline Sergipe & 0.687 & 13.2 & Acre & 0.757 & 21.5 \\
\hline Paráíba & 0.678 & 16.1 & Maranhão & 0.738 & 28.9 \\
\hline Piauí & 0.673 & 14.7 & Paraíba & 0.737 & 28.0 \\
\hline Maranhão & 0.647 & 17.4 & Piauí & 0.730 & 24.8 \\
\hline Halagaos & 0.633 & 18.3 & Alagoas & 0.703 & 31.4 \\
\hline
\end{tabular}




\begin{tabular}{|c|c|c|c|c|c|}
\hline -Table 4.6b: & HD & -Income and & $\begin{array}{l}\text { HDI-Health } \\
19912000\end{array}$ & & \\
\hline & $\begin{array}{l}\text { I-M } \\
\text { ome }\end{array}$ & & & $\begin{array}{l}\text { HDI-M } \\
\text { Health }\end{array}$ & \\
\hline & 2000 & $\begin{array}{c}\text { Growth }(\%) \\
1991-2000\end{array}$ & & 2000 & $\begin{array}{c}\text { Growth }(\%) \\
1991-2000\end{array}$ \\
\hline Distrito Federal & 0.842 & 5.5 & Rio Grande do Sul & 0.769 & 3.4 \\
\hline São Paulo & 0.790 & 3.5 & Santa Catarina & 0.762 & 4.1 \\
\hline Rio de Janeiro & 0.779 & 6.8 & Distrito Federal & 0.756 & 3.4 \\
\hline Rio Grande do Sul & 0.755 & 7.7 & São Paulo & 0.753 & 4.5 \\
\hline Santa Catarina & 0.750 & 10.2 & Paraná & 0.743 & 5.6 \\
\hline Paraná & 0.736 & 8.9 & Minas Gerais & 0.736 & 6.2 \\
\hline Mato Grosso & 0.719 & 8.8 & Rio de Janeiro & 0.727 & 6.1 \\
\hline Espírito Santo & 0.719 & 10.4 & Espírito Santo & 0.726 & 6.7 \\
\hline Mato Grosso do Sul & 0.718 & 6.7 & Goiás & 0.726 & 4.8 \\
\hline Goiás & 0.718 & 8.0 & Mato Grosso do Sul & 0.724 & 5.1 \\
\hline Minas Gerais & 0.711 & 9.5 & Mato Grosso & 0.722 & 5.4 \\
\hline Rondônia & 0.683 & 10.2 & Pará & 0.718 & 5.8 \\
\hline Roraima & 0.682 & -6.0 & Ceará & 0.709 & 13.0 \\
\hline Amapá & 0.666 & 2.4 & Amapá & 0.707 & 6.3 \\
\hline Pará & 0.643 & 7.4 & Piauí & 0.706 & 7.4 \\
\hline Acre & 0.640 & 5.4 & Amazonas & 0.704 & 6.9 \\
\hline Rio Grande do Norte & 0.636 & 10.0 & Tocantins & 0.703 & 7.0 \\
\hline Amazonas & 0.634 & -0.7 & Roraima & 0.699 & 6.9 \\
\hline Tocantins & 0.633 & 9.0 & Rio Grande do Norte & 0.690 & 9.0 \\
\hline Pará & 0.629 & 4.6 & Paraíba & 0.687 & 9.3 \\
\hline Sergipe & 0.623 & 7.0 & Acre & 0.679 & 7.6 \\
\hline Bahia & 0.620 & 8.4 & Bahia & 0.675 & 9.6 \\
\hline Ceará & 0.616 & 9.7 & Rondonia & 0.672 & 8.3 \\
\hline Paraíba & 0.610 & 11.3 & Sergipe & 0.668 & 9.6 \\
\hline Alagoas & 0.597 & 7.7 & Pará & 0.663 & 10.6 \\
\hline Piauí & 0.584 & 12.6 & Maranhão & 0.644 & 12.0 \\
\hline Maranhão & 0.558 & 10.4 & Alagoas & 0.597 & 16.2 \\
\hline
\end{tabular}

\section{INCOME INEQUALITY}

Part of the reason why the poverty indicators of Pará and those of the nation as a whole are worse than in other countries with similar per-capita incomes is because of income inequality. Both Brazil and Pará have an extremely unequal income distribution. In 2000, the Gini coefficient for Pará was 0.6, at par with the coefficient for the North region as a whole (Figure 4.8). Moreover, the income inequality has not changed during the last decade and remains stubbornly high. However, it is worth noting that international research shows that the more unequally income is distributed the less effective is economic growth in reducing poverty (Lustig et al 2001). 


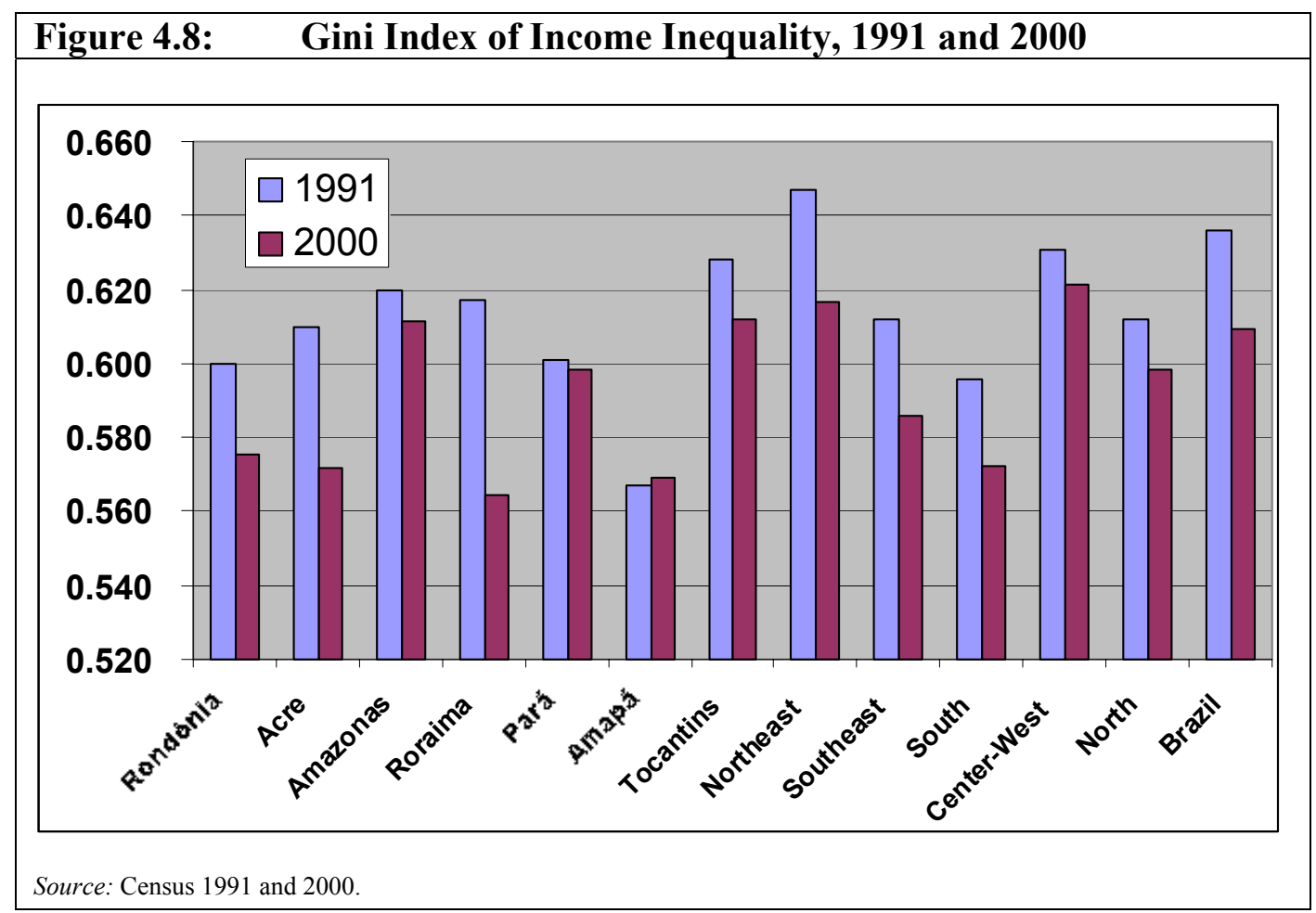

Changes in inequality are typically very slow, except during periods of radical social and institutional change. Where inequality has fallen it has usually happened in association with major expansion and equalization in educational attainment, as in Korea and Malaysia in the 1970s and 1980s. Pará's expansion in education (reduction in education inequalities) may have been too recent to have a significant effect on the composition of skills, and occurred during a period in which the overall returns to high levels of skills were rising and returns to basic skills were falling in Brazil.

\section{Poverty Profile}

After counting the poor we need to know who they are, where they live, and what they do. Comparing average levels of poverty for different categories is useful for learning about which population groups are falling behind or catching up in terms of poverty. This is useful for the design of policies: we would like to know, for example, whether urban-dwellers that are poor have a higher likelihood of experiencing poverty than rural-dwellers or more- or less-educated people are more likely to be poor in Pará, but also how the relative odds of being poor have evolved for these groups.

This section presents headcount poverty for various groups in Pará based on rural and urban sectors for 2000. Furthermore, it traces the evolution of the P0 for various urban population groups during 1981-2001. Hence, the poverty profile constructed is based on data from the Census 2000 and the Brazilian household surveys (PNADs 19812001). The main questions addressed are: (1) who are the poor, (2) what are the characteristics of poor households, (3) where do they live, and (4) where do they work. 
The structure of poverty is clear in Pará: (a) Indians, blacks, and pardos are poorer than whites, (b) young households/household heads are poorer than older households/household heads, (c) the poor tend to work more in the informal sector, and (d) a greater share of those engaged in agriculture are poor as compared to industry or services. Furthermore, the deepest poverty is in rural areas, and among the poorly educated, among the blacks and Indians, and young household heads with children. Without interventions to improve their opportunities and assets, their plight is likely to worsen. The social protection measures described in Section 6 are particularly relevant for them.

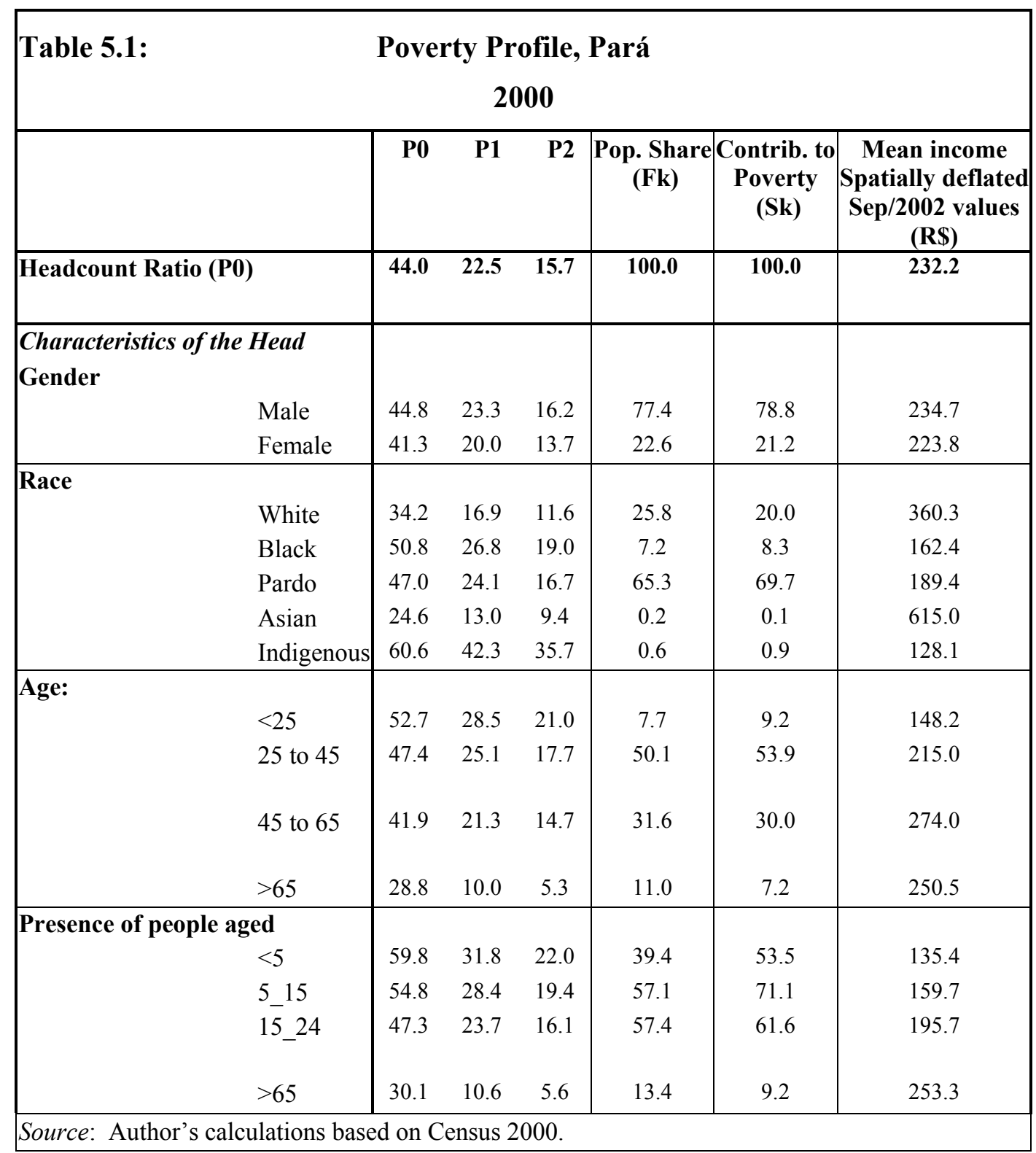




\begin{tabular}{|c|c|c|c|c|c|c|c|}
\hline \multicolumn{2}{|c|}{ Table 5.1 continued: } & \multicolumn{6}{|c|}{ Poverty Profile, Pará, 2000} \\
\hline & & P0 & $\mathbf{P 1}$ & $\mathbf{P 2}$ & \multicolumn{2}{|c|}{\begin{tabular}{|c|c|}
$\begin{array}{c}\text { Pop. Share } \\
\text { (Fk) }\end{array}$ & $\begin{array}{c}\text { Contrib. to } \\
\text { Poverty } \\
\text { (Sk) }\end{array}$ \\
\end{tabular}} & \begin{tabular}{|c|} 
Mean income \\
Spatially deflated \\
Sep/2002 values \\
(RS) \\
\end{tabular} \\
\hline & Urban & 37.6 & 17.5 & 11.6 & 69.2 & 59.1 & 275.0 \\
\hline & urb.village/city & 37.5 & 17.4 & 11.6 & 68.3 & 58.2 & 276.5 \\
\hline & n-urb.village/city & 46.3 & 22.3 & 15.3 & 0.8 & 0.8 & 147.7 \\
\hline & Isolated urb. & 50.0 & 22.1 & 13.5 & 0.0 & 0.0 & 116.7 \\
\hline & Rural & 58.4 & 33.8 & 24.7 & 30.8 & 40.9 & 136.4 \\
\hline & Urban extension & 43.9 & 22.3 & 15.7 & 0.2 & 0.2 & 201.8 \\
\hline & Povoado & 52.6 & 29.6 & 21.3 & 5.1 & 6.1 & 144.6 \\
\hline & Núcleo & 15.5 & 6.7 & 4.1 & 0.7 & 0.2 & 587.0 \\
\hline & outros aglom. & 0.0 & 0.0 & 0.0 & 0.0 & 0.0 & 0.0 \\
\hline & excl. aglom. & 60.8 & 35.4 & 26.0 & 24.9 & 34.4 & 122.1 \\
\hline \multicolumn{8}{|l|}{ Work } \\
\hline \multicolumn{2}{|c|}{ Signed Worksheet Yes } & 26.7 & 8.6 & 3.9 & 40.5 & 31.2 & 283.6 \\
\hline & No & 40.1 & 16.1 & 8.7 & 59.5 & 68.8 & 226.5 \\
\hline \multirow{2}{*}{ Econ. Active } & Yes & & & & & & \\
\hline & No & & & & & & \\
\hline \multirow[t]{2}{*}{ Working } & Yes & 38.7 & 16.4 & 9.3 & 69.7 & 61.3 & 268.5 \\
\hline & No & 56.2 & 36.5 & 30.3 & 30.3 & 38.7 & 148.8 \\
\hline \multirow[t]{7}{*}{ Work Sector } & Primary & 61.6 & 34.5 & 24.5 & 31.0 & 46.4 & 128.9 \\
\hline & Mineral Ind. & 14.9 & 5.7 & 3.2 & 1.0 & 0.4 & 442.4 \\
\hline & Secondary & 41.0 & 16.2 & 8.7 & 18.6 & 18.6 & 204.4 \\
\hline & Services & 31.0 & 11.8 & 6.2 & 33.9 & 25.5 & 335.0 \\
\hline & Social & 19.2 & 6.3 & 3.0 & 5.4 & 2.5 & 453.5 \\
\hline & Public & 20.0 & 7.2 & 3.6 & 6.0 & 2.9 & 430.2 \\
\hline & Other & 50.5 & 30.1 & 23.9 & 29.3 & 33.7 & 174.2 \\
\hline \multirow[t]{4}{*}{ Work Position } & Employee & 34.7 & 13.1 & 6.8 & 48.9 & 41.3 & 249.7 \\
\hline & Self-employed & 45.4 & 21.2 & 12.7 & 43.1 & 47.6 & 214.3 \\
\hline & Employer & 7.7 & 2.7 & 1.4 & 2.9 & 0.5 & 1396.0 \\
\hline & Unpaid & 85.1 & 70.0 & 64.0 & 5.1 & 10.6 & 41.1 \\
\hline \multicolumn{8}{|l|}{\begin{tabular}{|l|} 
Education: \\
Read and Write
\end{tabular}} \\
\hline & Yes & 39.6 & 19.8 & 13.6 & 78.7 & 70.7 & 267.4 \\
\hline & No & 60.5 & 32.6 & 23.2 & 21.3 & 29.3 & 102.4 \\
\hline \multicolumn{2}{|c|}{$\begin{aligned} \text { Years of Schooling: } \\
1 \text { to } 4 \text { years }\end{aligned}$} & 52.1 & 27.0 & 18.7 & 40.2 & 47.6 & 144.8 \\
\hline & 4 to 8 years & 39.9 & 19.2 & 13.2 & 19.6 & 17.8 & 202.5 \\
\hline & 8 to 12 years & 19.8 & 9.0 & 6.2 & 15.5 & 7.0 & 391.3 \\
\hline & More than 12 & 3.7 & 2.0 & 1.7 & 4.2 & 0.4 & 1222.8 \\
\hline
\end{tabular}


Despite some recent gains, Indians are poorer than whites, blacks, and pardos. The poverty profile based on Census data for 2000 reveals a large difference in the levels of well being among different racial/color groups in Pará (see Table 5.1 and Appendixes E and F). The Indians is the group that experienced the highest incidence of poverty in 2000. Of Indian heads of households, 61 percent had a per-capita income below the poverty line of $\mathrm{R} \$ 81$ per month. More Indians living in rural areas experienced poverty than their counterparts in urban areas, 76 percent compared to 39 percent and a larger share of Indians experienced poverty than their share in total rural population. Moreover, in 2000, the average income of Indians was one-third of whites' income and around 50 percent lower than the income of pardos. Indians, such as the Anambés, Xipaia-Kuruaia, and Surui Aikeware face more than income poverty. They also lack food and often face hunger mainly caused by increasing water pollution, small territories, and rapid deforestation that lead to scarcity of animal protein (Ricardo Verdum).

Blacks and pardos experience far more poverty than whites. The P0 reveals that 51 and 47 percent of households headed by blacks and pardos respectively are extremely poor compared to 33 percent of households headed by whites (Table 5.1 and Appendixes E and F). However, in rural areas, blacks and pardos are only slightly more likely to experience poverty than whites.

During 1993-2001, the falling trend in headcount poverty benefited all groups in urban areas except employers that experienced a small increase (2.2 percentage points). Poverty fell 5 percentage points among households headed by whites and 8 and 10 points, respectively, among those headed by blacks and pardos, which is much less than in the North region as a whole. In the North region, P0 for black and mulatto head of household fell 18 and 0.5 percentage points respectively. Hence, in 2000, 29 and 33 percent of the blacks and mulattos were poor in the North of Brazil, slightly less than in Pará (see Appendix E).

Education levels are strongly related to poverty. For example, being able to read and write is important in determining the likelihood of being in poverty. In Pará, the P0 is 40 percent for household heads that are literate, and 61 percent for those that are not. These headcounts are high compared to the national averages of 19 and 39 percent, respectively. The difference in P0 between the literate and illiterate is much lower in rural areas, 56 and 62 respectively, indicating the literacy may be less poverty reducing in rural then urban areas in Pará. The negative relationship between years of education completed and poverty is strong. There appears to be a relatively larger difference in P0 between household heads with no education (59 percent are poor) and household heads with 4-8 years of primary education (40 percent are poor). Household heads that have completed primary schooling and are enrolled or have finished secondary education are much better off ( 20 percent are poor) than those with only primary education. Of the household heads with more than 12 years of schooling only 4 percent were extremely poor in 2000. For all levels of completed education, P0 is higher in rural than urban areas and the difference is rapidly increasing with level of education. These findings indicate that education is a very important key to poverty reduction in Pará.

The gap in poverty between the educated and less educated is widening in urban areas. Since 1995, the more educated are experiencing less poverty, while the less educated are getting left behind. For each level of education (lower primary only, upper primary 
only, secondary only, and tertiary) the likelihood of being poor is estimated for urban areas in Pará. There are very large differences in poverty levels by education, and that they have increased during 1995-2001. Since 1995, the P0 for head of household with primary and secondary education appears to have increased, while the P0 for heads of households with some university education increased only slightly from its already very low level. In Pará, as elsewhere, there is a great deal of debate about the causes of these changes: skill-biased technological change, changes in the relative supply of and demand for workers with different characteristics, and trade liberalization have all been mentioned as possible explanations (Blom and Velez 2001; Blom, Pavcnik, and Schady 2001).

The younger the household head, the poorer the household. Data reveal that 53 percent of the households headed by a person younger than age 25 are extremely poor in Pará (see Table 5.1). Moreover, it is worrisome that the young rural-dwellers are much worse off, 62 percent are extremely poor (see Appendix F). Targeted social protection measures that relate to youth employment, family planning, and pre-school programs could help improve employment prospects of young people (see also below).

Elder household heads are far less likely to experience poverty than younger household heads. In Pará, only 29 percent of those households headed by a member older than age 65 are below the indigent poverty line. Additionally, the oldest age group has the highest average income of any age group, which may be explained in part by social assistance and pension reforms for elder household heads, the difference in P0 in rural and urban is very small ( 2 percent age points). The P0 of the population groups aged 25 to 44 percent and the group of 45 to 64 year olds was lower 42 percent in 2000 . Thus the younger the head of household, the more likely it is to be poor. This life-cycle profile of poverty illustrates that many households are born poor (mainly due to inadequate assets, see Section 6), with some escaping poverty as they accumulate more assets or as their household size shrinks.

The age of household members affects household poverty negatively. The more young children there are, the poorer the household. Among households with children under age five, 60 percent were extremely poor compared to 55 percent of those with children aged 5 to 15-24 respectively. Among households with a member older than age 65 the rate drops even further, to 30 percent. The P0 shows striking differences by age group: it is more than two times higher for children under age five than for people older than age 65. In the North the region as a whole, the households with young children are 4 times more likely to be poor. This is mainly because of the much lower poverty rate among the elder group in the Amazon.

Young, poor parents face high risk of being caught in a poverty trap. Young parents with low income, low level of education, and few assets may also suffer poor health. Their children receive low-quality education, and the parents have no access to kindergarten for the youngest offspring. Such young parents face a high probability of becoming unemployed, and have no access to employment benefits or other social benefits. This could lead to young poor parents being caught in a situation that is hard to escape, a poverty trap.

The difference in poverty rates across age has gone up over time in urban areas. Since 1995 , the poverty rate for young parents appears to have gone up, while the poverty rate 
for the old appears to have fallen (Appendix E). Very young parents in urban areas have a high-and growing-probability of being poor in Pará as elsewhere in the North region. There is considerable evidence from other settings that the benefits associated with early childhood interventions are very high indeed, especially for children from disadvantaged backgrounds, both because this is a critical stage in child development and because the returns to any productive investment in children accrue over a much longer period of time than the returns to productive investments in adults (see Heckman 1999; Currie 2001).

Informal workers suffer more poverty than formal workers. In Pará, 41 percent of the employed do not have a signed workbook, hence, are informal. The P0 for informal workers (sem carteira assinada-without a signed workbook) is high, 40 percent compared to 27 percent for formal workers. The informal poor, many of whom live in the urban periphery, earn a low and irregular income, own very few assets, and have no insurance against poverty. They face risks in the form of unemployment, crime, violence, and overall economic downturns. At the same time, it should be recognized that since very few people work in the formal labor market, social policies tied to formal employment or unemployment will have only very limited reach among the poor. Social protection policies need to allow informal workers to avail of them, while simultaneous efforts need to be made to encourage formal sector growth.

Female-headed households are not more likely to be poor than male-headed households, with 41 percent and 45 percent of female- and male-headed households, respectively, likely to be poor. The headcount poverty rates are higher for both groups in rural areas (see Table 5.1). It is worth noting that 23 percent of the females in Pará were headsof households compared to 77 percent of the males, hence the P0 of 40 percent for female household heads is relatively high. These income poverty figures are, however, only part of the myriad of factors that affect a poor woman's well being. The data do not reveal anything about domestic violence and other types of discrimination that women often face, nor the fact that women should have higher incomes, as they tend to have more education than men. Moreover, no attention is paid to other factors, such as employment and race in these simple poverty profiles (see Section 7).

Those who work in agriculture are far more likely to be poor than others. This suggests that productivity in agriculture is lower than in services or industry. The P0 is 62 percent among agricultural workers, but 31 percent among service workers, and 41 percent among industrial workers. The agricultural workers' poverty rate in Pará is similar to that of Pernambuco although the climatic differences are enormous (large parts of Pernambuco is semi-arid). This development pattern is different from that in mineral industry where $\mathrm{P} 0$ only reached 15 percent in 2000.

Historically, poverty in Pará has been closely associated with agriculture. In 2000, 31 percent of the extreme poor household heads cited agriculture as their primary form of employment. The main explanation for the high poverty rate in agriculture can be traced to migration and in part, to the structure of land ownership and land quality. Rural land ownership is characterized by a high degree of concentration of land in few large establishments and a large number of small farms with an insufficient area to sustain a family by agricultural employment alone. In the last decades, the land concentration increased. Moreover, the most skilled agricultural workers have shifted employment out of agriculture toward higher wage jobs in the service sector. 
Rural poverty fell in recent years but it is still larger than urban poverty. More than one-third of Pará's poor population lives in rural areas, with limited access to basic infrastructure and services. The rural poor are primarily smallholders and informal wageworkers that depend on a diverse strategy of income-generating activities in which subsistence production predominates. These small farmers lack titles to obtain access to credit, modern production technology, basic infrastructure to store harvests to take advantage of cyclical price fluctuations, technical assistance to improve productivity, and organized marketing facilities. Family income is therefore highly variable and there is little opportunity for saving. They have very few assets, including education and documents, such as birth certificates, and, therefore, often very vulnerable.

A multi-pronged approach is called for to reduce rural poverty. The differing characteristics of the smallholders and wageworkers suggest that a poverty reduction strategy needs to provide multiple paths out of poverty tailored to the heterogeneous cross-section of poor rural households. A national study for Brazil ${ }^{7}$ suggests that this will involve at least a three-pronged approach aimed at: (i) small farm sector intensification, (ii) improved employment opportunities in dynamic commercial agriculture, (iii) growth of the rural non-farm sector and, provision of safety nets for those "trapped" in poverty. The recommended measures include: improving human capital endowments; reforming the land, labor, and financial markets; enhancing research and extension; improving the supply of public goods and services; pricing and trade policies; and, transfer programs. One important first step would be to ensure that everybody have documents, which give children access to school and healthcare, poor parents access to conditional cash-transfers, and old people access to pensions and benefits.

In order to increase land productivity and labor-intensive farming, it is necessary to facilitate the movement toward farming medium-sized land holdings, in part via facilitating land rentals and sharecropping arrangements. ${ }^{8}$ This can be done by providing more secure titles to land and by the revision of the land legislation so as to secure longer-term tenancy arrangements, resolution of disputes regarding interpretation, and enforcement of land rental arrangements. The impact of such a program would be greatly enhanced by simultaneous adjustments of the labor code and of the land tax system. Labor laws have had an anti-sharecropping bias. In this context, the experience with the Rural Leasing Exchange in the Triângulo Mineiro contains useful lessons that are worth considering for Pará.

A more direct way of improving farm productivity and revenues is via the communitybased approach to land reform. Under this approach, beneficiary groups negotiate directly with potential sellers of suitable properties, and then obtain financing for the purchase of the land and complementary sub-projects and receive technical assistance.

\footnotetext{
${ }^{7}$ See World Bank 2001a.

${ }^{8}$ ibid.
} 


\section{Access to Services and Assets}

The problem of social exclusion, poverty, and inequality in Pará largely reflects disparities in opportunity. The distribution of key productive assets - labor, human capital, physical assets, financial assets, and social capital - is highly unequal. These disparities are most prevalent between the poor and non-poor, but also manifest themselves differently by geographic area. Also access to services is unequal. This section addresses social exclusion in a few of these areas, namely labor, education, and social protection.

\section{LABOR}

Labor is the rural and urban poor's most abundant asset and it accounts for nearly all of their total income. Nonetheless, the poor are constrained in their use of this asset in a number of ways: (1) high level of unemployment; (2) a strong correlation between informal sector employment and poverty; and (3) black, pardo and female workers face probable wage discrimination. Data shows that formal sector employment has not been able to keep up with population growth in Pará.

The poverty analysis reveals that many workers in Pará, particularly those in the informal sector, are poor. The challenge of creating employment is therefore to increase the number of jobs that are able to provide sufficient income to lift the employee's household out of poverty or cushion against it. Creating jobs regardless of quality is not enough - people need good jobs. As the labor market, particularly the informal one, is relatively flexible, the worry is about generating sufficient income via employment rather than simply having a job. The trend in this regard, as reflected by decreasing real wages of informal workers in Brazil, is discouraging.

According to the Census 2000 data, the labor force in Pará counts 4.7 million people over 10 years of age, that is, 75.8 percent of the total population. In Pará, less than the majority of the participants in the labor force are active (49 percent), a smaller share than in Brazil as a whole (55.9 percent). Moreover, 51.1 percent of the labor force received no income and 19.1 percent earned less than one minimum salary of R $\$ 151$ in 2000. Of the Paráenses that worked in the reference week of the Census 2000, 13.7 percent was engaged in activities contributing to own consumption, i.e. around the double of that in Brazil as a whole (6.9 percent). These figures are in line with the information obtained during field visits in Pará, which clearly indicate that in the rural dwellers, including the Quilombos, Riberinhos, and other populations, do not earn any income from their activities. In many rural areas in the North and Northeast of Brazil, the majority of the money circulating originates from pensions and conditional-cash transfers, such as Bolsa Escola (see below).

The demographic change that demands the most urgent policy response is the sizeable growth in the economically active population. Some of the growth in the economically active population is from in-migration, but most of it is natural growth. The high rate of growth of this age cohort-along with increasing female participation in the labor force-means that a high number of good new jobs are needed each year to keep pace, and better jobs are needed by those already in poor jobs. This is a major challenge. 
In the longer term, the slowdown in Pará's population growth (see Section 2) will affect poverty through its broader effects on the labor market. The rapid population growth experienced in previous decades has resulted in an elastic supply of unskilled labor. As a result, wage levels have remained low - except for high skill, well educated workers even in times of high economic growth. Pará's lower fertility rate will eventually moderate this factor. Declines in the growth of the labor force will reduce the supply of labor. This may result in increasing pressure on wages, which in turn may prompt the substitution of capital for labor, increasing labor productivity, and setting off a virtuous cycle of rising wages and rising productivity.

The state government should support the federal government's attempts to reform the labor code in order to reduce costs of employment creation in the formal sector. The labor code in Brazil relies more on a rigid legislative code than on collective bargaining. The reform of the labor code is the best way to encourage increased formal employment, which should also help reduce the formal/informal divide. By shifting that balance, Brazil could reduce labor turnover, increase productivity, decrease payroll costs, expand the formal labor market and social security coverage, and lessen the reliance on litigation. Possible measures would entail realigning incentives for hiring, retaining, and firing workers and relaxing rules, including mandated minimum nonwage benefits, to leave more to decentralized collective bargaining.

Child labor is still a severe problem in Pará as well as in the Amazon as a whole. International evidence shows that child workers tend to be poor and complete fewer years of schooling than their non-poor counterparts. Children should not have to work, but an estimated 250 million children are working worldwide. Child labor is one of the most devastating consequences of persistent poverty. Data reveal that 18 percent of children in Pará worked in 1999 (Figure 6.1). Child labor in Pará is slightly higher than in the region and Brazil as a whole. However, the majority of child laborers may be both working and studying. Vital to achieving progress against harmful child labor are: (i) effective efforts to reduce poverty generally; and (ii) the economic and social policies, programs, and results that are the underpinning for success in poverty reduction. But these broad measures, while important, take time and are not sufficient by themselves. Additional actions focused specifically on child labor per se are also needed, such as an expansion of PETI (see below). 


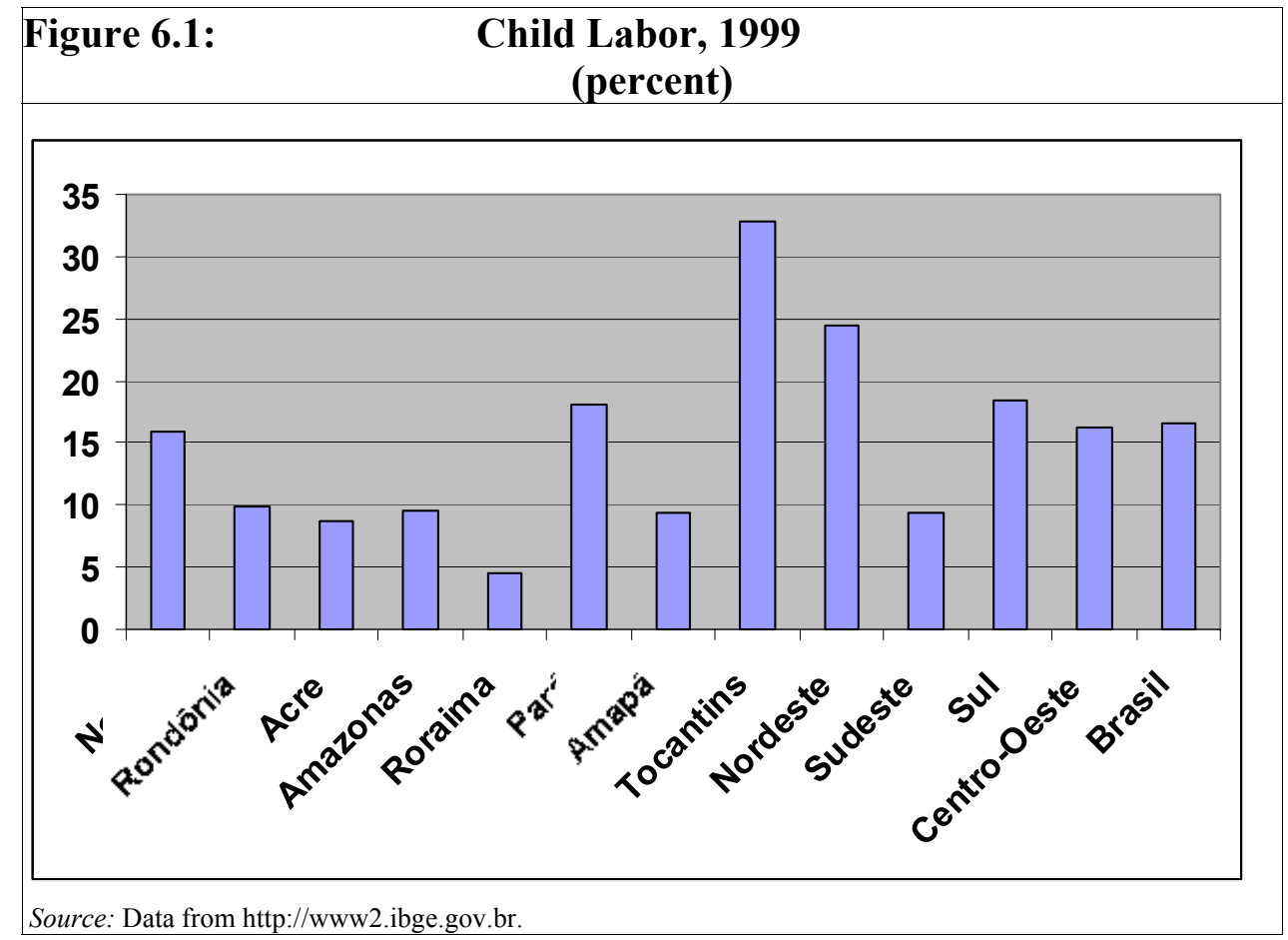

\section{EDUCATION}

Education is key to poverty reduction (see Sections 5 and 7). Increased educational attainment can improve the livelihoods of the poor and reduce the likelihood of becoming poor. More education is also a key factor in obtaining a higher income (see Appendix D). Furthermore, education is associated with fertility: the more education a woman attains, the lower her fertility rate and, therefore, the lower the dependency ratio and the lower the likelihood of falling into poverty. Therefore a clear message is that the Paráenses as well as the rest of the people in the Amazon need to be brought up the educational ladder to escape poverty.

Furthermore, human capital - education and health - is an important complement to labor, boosting its productivity and potential for income generation. Each year of schooling yields an increase in hourly earnings. Disparities in education are key causes of poverty and inequality. Education is also a crucial elevator for the poor to lift themselves out of poverty. Higher educational attainment for a household head significantly reduces the probability of being poor (see Sections 5 and 7).

Pará has made progress in education and in 2002, more than 95 percent of children and youth aged 7-14 were in school. Since the number of those under age 14 is not growing (see Section 2), Pará has been presented with an excellent opportunity to increase access of the poor above fourth grade and improve the quality of primary education. At both the national and state level, governments have raised education's share of the public budget and introduced policy changes aimed at improving access to primary education, increasing enrollment in secondary school, and diminishing regional disparities. Although progress has been made in increasing educational attainment over time, gaps remain for the poor Indians, blacks, and pardos. 
In Pará, school enrollment for the 7-14 age group from poor households and areas is low. Enrollment of children from poor households is slightly lower than enrollment from non-poor households. However, regional differences are large, in Altamirum 124 percent of the 7-14 year olds are enrolled compared to 69 percent in Tucuruí. Also the growth of primary school enrollment has increased, but less than the North region as a whole (Figure 6.2).

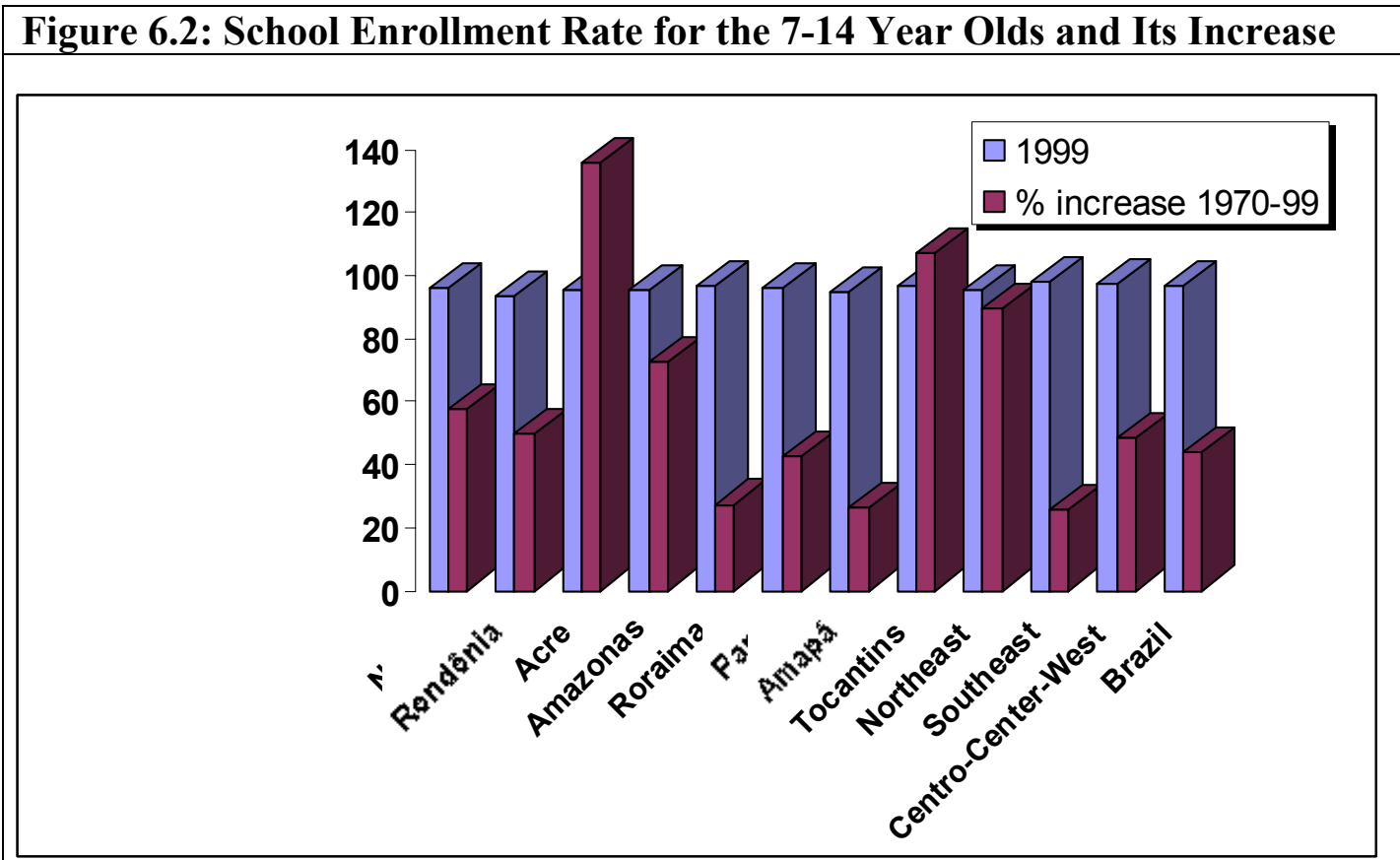

Source: Data from http://www2.ibge.gov.br.

School attendance of poor students increased but it still lags behind non-poor students. In Pará, as in the rest of Brazil, children from richer households have on average a higher school attendance, are less likely to repeat a school year, and have more completed years of schooling than children from poor households. Data reveal a strong correlation between poverty and educational attainment. The level of education of the extremely poor is the lowest, and it is also increasing more slowly than average. In 1981, the average year of scholling in urban areas was 5.2 years but for the indigenous poor it was only 3.8 years. Two decades later the picture did not change very much, except that the average increased by 0.8 years to 6.0 years for the non-poor, while the average incresase for poor students were only 0.5 years to 4.2 years. Hence, the poor are not catching up with the non-poor part of the population in Pará, which does happen in Brazil as whole.

Students in rural areas lag behind their urban counterparts. Tremendous strides have been made in improving access of the poor to basic education. However, inequalities remain between rural and urban dwellers. The primary school students in rural areas attained 0.8 years education than their urban peers. The rural poor tend to lag behind their urban counterparts in their access to services because of their initially lower starting point and greater improvements in service delivery in urban areas. 
While the quality of education as reflected in test scores, repetition rates, age-grade distortion, school attainment, and literacy leaves much to be desired; the schools themselves, equipment (there are no longer alumnos jacaré (students that attend classes, laying down on the floor), and the qualification and dedication of the teachers in the North are generally good, though the teachers did not always make it to class. This suggests that targeted teacher training and monitoring of teachers may be useful in Pará and the region as a whole.

The state government could improve its commitment to improving education in Pará. 9 Education spending has been steadily increasing. In 2001, Pará spent R $\$ 663$ million on education, 13 percent more thant in 2000. Currently, Pará spends a much lower share of its income on education than the average of the North region (3.8 percent). Only Amazonas in the North region spends a lower share of its income on education than Pará does. However, education's share of total GDP fell 1.1 percentage point to 2.8 percent during 1998-2000 (Appendix 2B).

Pará lags in pre-school programs. The group of children that has suffered the greatest lack of educational attention is the pre-school group. As the legal responsibility for the provision of pre-school has shifted to the municipal level, the number of pre-school places in Pará actually declined in recent years (as in the other states). Daycare and early childhood education represent a future investment in the human capital of the state, and should be a priority over the long term. Studies have shown that children who have attended pre-school perform better academically than those who have not. Programs have been in place to monitor and improve the health outcomes of small children - from early pregnancy through the first years of life. Given the high incidence of poverty and vulnerability among families with children under age five (see Section 5), and given the increased economic participation by women, a program of financial transfers linked to early childhood development and education centers (along the lines of Bolsa Escola and PETI, see below) could be influential in reducing poverty. The state government launched the Maria-Maria program and the federal government has recently launched the Bolsa Alimentação, a program of financial tranfers to the mothers of children age five and younger, linked to stringent prenatal, postnatal, and developmental checkups by health professionals. These types of programs could be linked to and used as the vehicle for strengthening and expanding early childhood education and care. The fact that many children and adults in remote areas of Pará lack birth certificates and other papers, it is unlikely that Bolsa Alimentação and other social programs will benefit many of the poorest families in Pará.

Policies to improve access of the poor to early childhood development programs, kindergartens, and secondary and higher education linked with improved quality of education should be the core of the government's poverty-reduction strategy.

\footnotetext{
9 The progress made in recent decades has been due to increased resources devoted to education, increased priority placed towards primary education, increased responsibility given to municipalities for education delivery, and a number of federally-funded programs. At present, about half the public funding for education is provided by the state, about 30 percent by municipalities, and the remaining 20 percent by the federal government, usually through programs implemented by municipalities.
} 
Furthermore, to reduce disparities in human capital targeting of social policy and public spending is called for to reduce spending on education.

\section{SOCIAL PROTECTION}

Recognizing that economic growth and social investments in education (and health) will still leave many in extreme poverty. The state and federal governments have a variety of programs aimed at reducing economic insecurity and targeted poverty reduction. The programs fall into three categories: (i) those dealing with life-cycle considerations, such as social security and pensions; (ii) those dealing with income volatility, such as unemployment insurance; and (iii) those dealing with social protection, aimed at improving the well-being of specific vulnerable groups.

The social protection programs in Pará include for example conditional cash-transfer schemes, employment and income generation programs, and programs to combat child labor and sexual abuse. In addition, there are health and education programs aimed at building sewerage and keeping children in school. This section will describe some of the social protection issues and assess the policies of the government in dealing with them. In doing so, it will focus on two major social protection programs: the federalfunded Bolsa Escola and PETI (Child-Labor Eradication Program).

The basic approach to address children and youth could be linked to a life cycle and social risk management approach to human development. This means moving beyond survival goals to issues of basic education, health, social capital and a general flourishing condition for development. The well-being of children is more than a matter of current projects or interventions. Children are the basis for the future health and well being of their communities, and a key to breaking cycles of inter-generational poverty. Harmful child labor is an especially strong impediment to a future of good health and high productivity (see above).

It is not only children that confront challenges, but each age group faces challenge. Children are among the most vulnerable. The 0-to-5 age group faces the risk of stunted development. In Pará, public policy seeks to address this via early development programs. The education sector plays an important role by improving access to preschool and kindergarten, particularly for the poor. However, this group experience increasing coverage via the Maria-Maria program.

The 6-to-14-age-group faces the risk of low-quality education, child labor, and sexual abuse. The social assistance programs in Pará to assist this group are Bolsa Escola (to increase school access) and PETI (to eradicate child labor). This age group has good coverage, but demands are still not fully met (see the analysis below).

The 15-to-24 age group faces the risk of poor secondary education, including poor school attendance, completion, and quality. In addition, the labor market participants from this group face the same risks as those in the 25-to-65 age group (see below). The same policy responses apply as to the 6-to-14 age group. However, the poor from this age group are less well covered because there are no Bolsa Escola programs available for them. The 25-to-65 age group faces risks of low income, underemployment, and unemployment. Job-creating growth programs and labor market reforms are key to 
reduce these risks. Current social policies - unemployment insurance, severance pay (FGTS), and the pension system - cover employees in formal employment for loss of income or job. Formal sector workers are well covered, perhaps excessively so. The group at risk is the two-thirds of the labor force working in the informal sector that does not have access to any social insurance programs, which gives access to low-paid workfare programs, constituting a form of basic risk coverage. The Programa Nacional de Geração de Emprego e Renda (National Program for Job and Income Generation, PRONAGER) helps the unemployed to increase their job opportunities. During 19952001, PRONAGER benefited 6,086 people in seven municipalities in Pará. Hence, 145 municipalities still do not participate in the program.

The group age 65 and older faces the risk of low income. The role of social protection is to supply pensions to this age group. The contributors to the social insurance system (contributory pensions) face little risk because they are insured. The role of social assistance is to provide income transfer to the group that is not insured. The risk for this age group is currently fairly adequately covered.

Many of the programs find it difficult to reach the very poorest. A recent study of Brazil found that of the total spent on social programs, 14 percent accrued to the first quintile of the income distribution (World Bank 2001). Many programs lack broad reach amongst the poor, good targeting, or both. Some guidelines for the design of good social programs are provided in Box 6.1.

The federal-financed Bolsa Escola and Programa de Erradicação do Trabalho Infantil (Child-Labor Eradication Program, PETI) programs are designed to increase school attendance and attainment and to reduce child labor by providing financial transfers (grants) to families who abide by certain rules. The target group is children aged 7 to 14 from poor households. The programs are widely seen as successful, both in terms of improving educational outcomes and improving family welfare of the recipient families. In Pará, 439,339 children participated in the Bolsa Escola program in 2000. In 2003, 318,056 children participated in the PETI program.

One welcome side effect of these two programs stems from the way that they are administered. The programs specifically give the money to mothers of the participating students. The thinking is that this will increase the likelihood that the funds will go to the improvement of the welfare of the family as a whole and of the children in particular. This is the first time many of these women have been entrusted with this kind of financial responsibility, or have opened a bank account. This "official recognition" has also led to a greater recognition and valuation of women's role in the family - including by their partners - and in many cases has increased the women's self-confidence. In field visits by the World Bank, the money received by the mothers through the Bolsa Escola and PETI programs is repeatedly mentioned by both men and women as one way in which gender relations and the roles of men and women are slowly changing. 


\section{Box 6.1: Design of Social Programs}

Better targeting requires different approaches for different programs. For universal programs, such as education, health, and urban services, the targeting of public spending can be improved without abandoning universality. True universalization of services from which the poor are mostly excluded is, in fact, synonymous with targeting the poor for service expansion.

Several principles are useful to follow. First, public spending should focus on spending items that disproportionately benefit the poor (such as schools, health facilities, and water supply in poor areas, or education initiatives targeted at reducing repetition rates in school). Second, some government services could require cost recovery for the non-poor. For insurance programs, such as pensions and unemployment insurance, contributions and benefits should be set such that public funds are used only for transfers targeted to the poor. Income transfers and related programs should be strictly tied to a means-testing procedure. In particular, public spending for income transfer programs should be focused on the very poorest. Third, often an effective way of targeting the poor is to provide goods which are not well-liked by the non-poor, such as a cheap but nutritious food.

There needs to be rigorous monitoring of the efficiency and effectiveness of social programs. Demand and willingness to pay serve as the basic guidelines to estimate program benefits. Investments and current transfers should be compared on the basis of cost-benefit and transfer effectiveness analyses. Redistributive objectives should not be used to justify bad investments. Social investments should pass an efficiency test demonstrating that they are more cost-effective than income transfer programs in bringing monetary or non-monetary benefits to the poor.

The design of social programs should correspond to the demand of the beneficiary population and include genuine beneficiary participation. In general, this implies that service provision should be at the level of willingness to pay. Cash and voucher programs are preferable to in-kind service provision, unless the latter is justified by better targeting or externalities. In some cases, a switch from in-kind to voucher financing can be an effective means to increase transparency, consumer choice, competition, and internal efficiency. Beneficiary participation in program design, implementation, monitoring, and evolution is essential.

An increasing share of social policy is implemented at the state and municipal level, especially in education, health, and social assistance. Thus, any social spending reform must include reforms at the state and municipal level. Social spending reform at the state and municipal level revolves around three objectives. First, reforms should improve incentives for providing service to the poor. This could include conditional cash transfers. Second, the responsibilities of the different levels of government should be clarified where they are unclear. Finally, reforms must attempt to strengthen the capacity of states and municipalities to deal with poverty-related issues.

Source: World Bank (2001).

Two issues that arise in the implementation of the poverty alleviation strategy are targeting and institutional arrangements. Targeting seeks to distribute transfers or other benefits only to those identified as the beneficiary group in the interest of efficiency. The administrative mechanism must not cost so much to operate that it effectively absorbs the savings from excluding the non-needy. In Pará, geography is one of the indicators with the greatest value as a targeting mechanism. Another good targeting 
mechanism is individual or family characteristics. Some characteristics are closely associated with poverty and suggest the types of assistance, which would mainly benefit the poor. Nearly all households, that draw their water from wells are poor. Other housing characteristics closely associated with poverty include the use of latrines and the absence of household lighting or sanitation facilities.

The magnitude and seriousness of the poverty in Pará call for the active participation of all resources, including non-governmental organizations (NGOs). NGOs have several strengths. They can mobilize and utilize substantial levels of resources, and they are also able to reach underserved populations effectively. NGOs are a strong constituency for the promotion of poverty alleviation goals and programs. There are many NGOs in Pará covering different fields, sectors and areas of the state. One NGO worth of mentioning is Saude-Alegria in Santarém working with Riberinho communities on reducing infant mortality, hunger, and other health related issues.

NGOs also have some weaknesses. They are often vulnerable and have difficulty formulating policy proposals. Collaboration with the government is constrained by real and perceived barriers. The dispersion of government responsibilities over a broad range of state agencies makes NGO entry difficult. Also, NGOs differ as to their management and administrative capacities. Some government agencies view NGOs as competitors instead of potential executing agencies. Mistrust hinders collaboration. The government should establish clear and efficient mechanisms for NGO collaboration. Emerging NGO consortia provide one mechanism, which should be explored for fostering greater coordination, dialogue, and joint planning with the government.

\section{Poverty Correlates}

The previous sections examine the disparities in key assets between poor and non-poor. This section takes the analysis a step further and analyzes the relative importance of these and other correlates of poverty in a multivariate setting, and investigates the marginal impact of each individual attribute on the likelihood of a household falling below the indigence poverty line, taking into account other characteristics. The section analyses the impact of experience, labor market association, different levels of education, etc. on the likelihood of being poor for: (1) urban and rural dwellers in Pará, and (2) urban Pará and urban Brazil as a whole. Given the way the regression model is specified, findings reveal when impacts for: (1) rural dwellers are different from impacts for Pará as a whole, and (2) urban Pará is different from urban Brazil as a whole. The status of the household-poor or non-poor-is regressed on relevant individual and household characteristics using the probit-regression technique. The analysis presented in this section is based on the Census 2000 data and PNAD 2001.

The analysis of poverty correlates reveals a conditional correlation between poverty and characteristics of household heads and indicates groups that are particularly vulnerable. The probability of a household being poor is analyzed based on relevant individual and household characteristics. The main conclusion emerging from the analysis is that disparities in assets - education and labor - are indeed strongly correlated with poverty in Pará.

Other poverty studies for Brazil as a whole such as Ferreira, Lanjouw, and Neri (1998), show that in 1996 education was the central personal attribute determining the 
likelihood that a household would experience poverty. Other factors, such as age, family size, race, and rural living are also important in determining the likelihood of poverty. Most of the findings on Pará, presented in this section, are very much in line with those of Ferreira, Lanjouw, and Neri.

It is important to note the limitations of this analysis at the outset. First and foremost, the analysis does not capture the dynamic impact of certain causes of poverty over time. Most notably, the impact of changes in economic growth - most certainly a key determinant of poverty - cannot be assessed using this static, cross-section model. Second, the analysis is limited by the variables available at the household level from the 2000 Census and 2001 PNAD. Other factors - such as social conditions like crime and violence, or physical conditions, such as variations in climate or access to markets could not be included due to a lack of data at this level. Finally, though theory holds that many of the variables included in the analysis do indeed contribute to (cause) poverty (or poverty reduction), the statistical relationships should be interpreted as correlates and not as determinants since causality can run both ways for some variables.

Living in rural areas in Pará does not by itself affect the probability of being poor. Rural living in itself is a statistically insignificant correlate to poverty. Hence, individual and household characteristics are more important than geographical location (see Table 7.1). This is good news for policy-makers as there are no non-measurable rural variable kicking-in and affecting the likelihood of a household head in Pará falling below the poverty line. ${ }^{10}$ Hence, the deep rural poverty in Pará is due to, for example, lower education achievements and skill levels and not to rural living per se. Households located in rural Pará are not more or less likely to experience poverty than in the rest of Pará, which may indicate that rural dwellers in Pará have developed some forms of coping strategies. Policy interventions that facilitate poor rural people's access to basic services and expanding high quality rural education are central to poverty reduction in Pará (see below). The largest statistical differences in poverty reduction between rural and urban areas are found in the effect of education, sector of employment, gender, and family size.

Living in urban areas in Pará does not by itself affect the probability of being poor more than in Brazil as a whole. Statistically, findings presented in Table 7.2 show that the main difference in poverty correlates between urban Pará and urban Brazil is also related to individual or sectoral characteristics. Hence, public policies have an important role in leveling such differences, for example, high school's impact on poverty in Pará tend to be higher than in Brazil as a whole indicating a scarcity in highschool graduates in Pará.

\footnotetext{
${ }^{10}$ One explanation may be that the data are adjusted by regional prices, which affect the rural dummy variable (Ferreira, Lanjouw, and Neri 1998).
} 


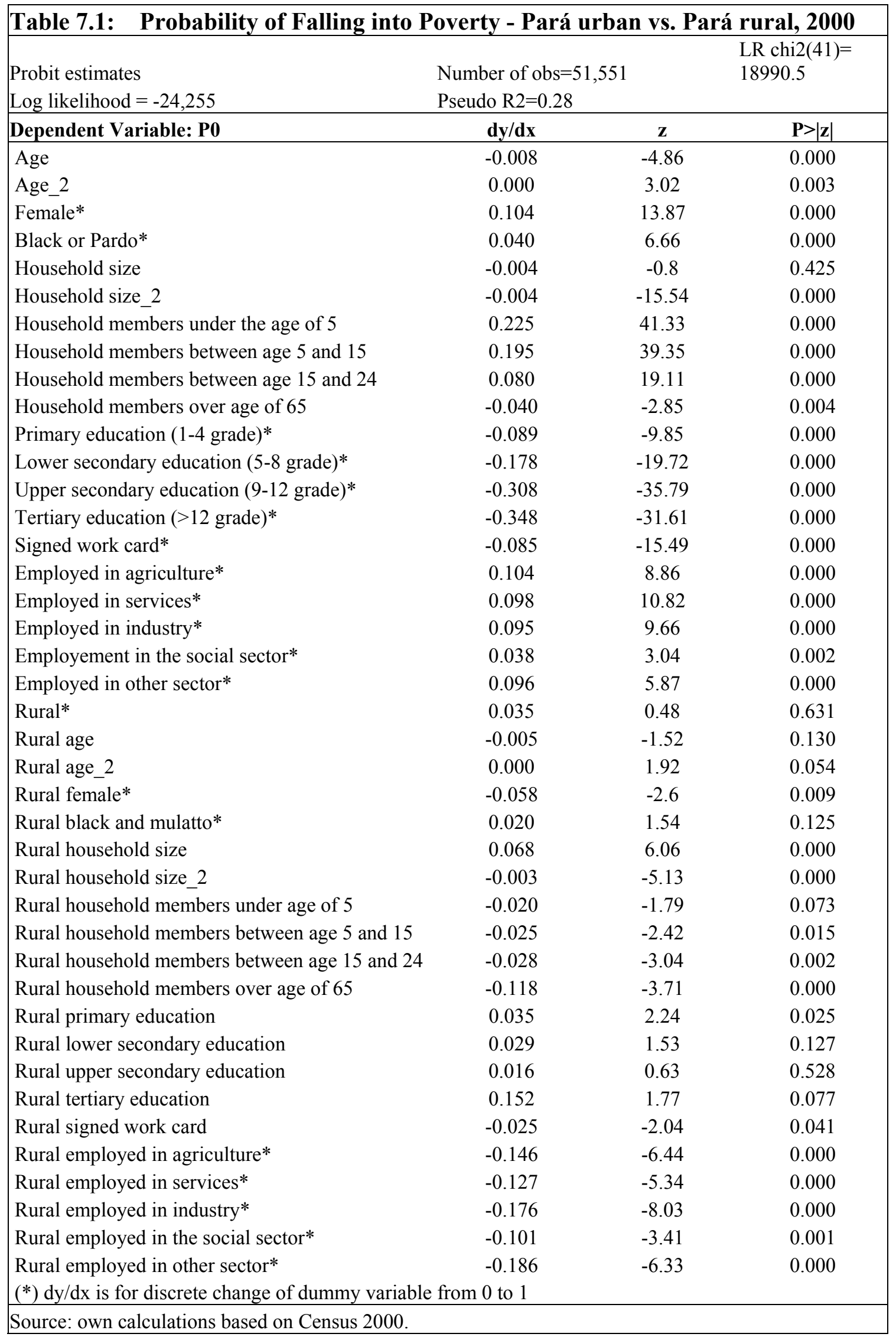




\begin{tabular}{|c|c|c|c|}
\hline \multicolumn{4}{|c|}{ Probit estimates, Pseudo R2 $=0.34, \log$ likelihood $=-12070$, Number of obs $=38885$, LR chi2 $(45$} \\
\hline Dependent Variable: P0 & dy/dx & $\mathbf{Z}$ & $\mathbf{P}>|\mathbf{z}|$ \\
\hline Age & -0.0036 & -3.55 & 0.000 \\
\hline Age squared & 0.0000 & 2.56 & 0.011 \\
\hline Female & 0.0495 & 10.73 & 0.000 \\
\hline Black & 0.0626 & 9.35 & 0.000 \\
\hline Mulatto & 0.0746 & 22.26 & 0.000 \\
\hline Asian & -0.0339 & -0.88 & 0.377 \\
\hline Family size & 0.0257 & 5.4 & 0.000 \\
\hline Family size squared & -0.0048 & -10.64 & 0.000 \\
\hline Family member below age 5 & 0.1208 & 31.3 & 0.000 \\
\hline Family member age 5-15 & 0.1034 & 28.53 & 0.000 \\
\hline Family member age $15-24$ & 0.0400 & 13.39 & 0.000 \\
\hline Family member above age 65 & -0.0598 & -5.36 & 0.000 \\
\hline School 2 & -0.0433 & -10.48 & 0.000 \\
\hline School 3 & -0.0633 & -15.41 & 0.000 \\
\hline School 4 & -0.1198 & -27.53 & 0.000 \\
\hline School 5 & -0.1155 & -19.23 & 0.000 \\
\hline Formal Sector & -0.1013 & -29.02 & 0.000 \\
\hline Agriculture & 0.1244 & 9.12 & 0.000 \\
\hline Service & 0.0178 & 2.03 & 0.043 \\
\hline Industry & 0.0186 & 2.03 & 0.042 \\
\hline Social & 0.0164 & 1.48 & 0.140 \\
\hline Other & -0.0264 & -1.68 & 0.093 \\
\hline Pará & -0.0272 & -0.37 & 0.711 \\
\hline Pará Age & -0.0011 & -0.27 & 0.786 \\
\hline Pará Age squared & 0.0000 & 0.3 & 0.766 \\
\hline Pará Female & 0.0096 & 0.61 & 0.539 \\
\hline Pará Black & -0.0352 & -1.78 & 0.075 \\
\hline Pará Pardo & -0.0374 & -3.32 & 0.001 \\
\hline Pará Asian & 0.1970 & 0.99 & 0.321 \\
\hline Pará Family size & 0.0027 & 0.17 & 0.864 \\
\hline Pará Family size squared & -0.0003 & -0.26 & 0.797 \\
\hline Pará Family members below age & 0.0094 & 0.66 & 0.510 \\
\hline Pará Family member age 5-15 & -0.0087 & -0.67 & 0.505 \\
\hline Pará Family member age 15-24 & -0.0004 & -0.04 & 0.970 \\
\hline Pará Family member above age 65 & -0.0351 & -0.69 & 0.490 \\
\hline Pará school 2 & 0.0422 & 1.96 & 0.050 \\
\hline Pará school 3 & 0.0019 & 0.09 & 0.926 \\
\hline Pará schol 4 & 0.0403 & 1.84 & 0.066 \\
\hline Pará schol 5 & 0.0219 & 0.35 & 0.723 \\
\hline Pará Formal sector & 0.0405 & 2.86 & 0.004 \\
\hline Pará Agriculture & 0.0642 & 1.28 & 0.202 \\
\hline Pará Service & 0.1294 & 2.59 & 0.010 \\
\hline Pará Industry & 0.1341 & 2.6 & 0.009 \\
\hline Pará Social & 0.0494 & 1.0 & 0.318 \\
\hline Pará Other & 0.1797 & 1.67 & 0.096 \\
\hline
\end{tabular}


Gender of heads of households affects poverty less in rural areas than urban areas. Households headed by women are more likely to be poor than those headed by men. Female-headed households have a much larger likelihood of being poor than do maleheaded households when other covariates are included in the analysis, such as labor market connection and education (Table 7.1). Moreover, female-headed households in urban Pará are less likely to be poor than female heads in rural areas in Pará. The findings from the comparison of urban Pará and urban Brazil (Table 7.2) reveal no statistical difference between female headsof households in urban Pará and urban Brazil as a whole. In all areas, women are far more likely to experience poverty than men. Hence, social policies favoring women, such as conditional-cash-transfer programs (for example, Bolsa Escola and Bolsa Alimentação) where the mother receives the benefit should be strengthened both in urban and rural areas (see Section 6). Furthermore, introducing more kindergarten and childcare facilities for poor mothers could facilitate poor urban women's labor market participation.

The effect on poverty of race of head of household is strong in Pará. The race/color background is another important factor contributing to poverty. In all the analyses performed, blacks and pardos are far more likely to fall into poverty areas than their white peers. The probit regression findings show that pardos and blacks have a higher incidence of poverty than their white peers in both urban and rural areas, controlling for other characteristics. Moreover, it is interesting to note that the effect of black and pardo headed households on poverty in rural Pará is not statistically different from urban Pará. However, blacks and pardos in urban Pará have a higher likelihood of falling into poverty than their peers in the rest of Brazil's urban areas (Table 7.2). Hence, family and education variables capture only part of the difference found in the simple unconditional mean incomes (Section 5), but still a large part is due to discrimination or other unexplained individual characteristics of the non-white population group. Policies to assist access to high quality education and health care for poor families that take into account the reality of blacks and pardos are key to change this picture.

Education is the strongest poverty reduction correlate. All levels of education from primary to tertiary are strongly statistically significant and negatively associated with the probability of being poor in Pará (Tables 7.1 and 7.2). The more education attained, the less likely it is that the household head falls below the poverty line. The impact of having completed grade 1-4 of primary education on the likelihood of being poor is the lowest. For high-school graduates, the estimated impact is much larger (4 times) than that of grade 1-4 of primary education. Furthermore, completed tertiary education reduces poverty more than completed secondary education. For university graduates, the likelihood of falling below the poverty line is 5 times lower than that of completed grades 1-4 of primary education. Moreover, it is interesting to note that the likelihood of falling below the poverty line is higher for university graduates in rural areas than in urban areas. This is also the case for household heads that only partly or fully completed primary school and secondary school.

Labor market connection is important for the probability of falling into poverty. Households where the household head works in the formal sector were less likely to be poor than others. In Pará, the poverty reducing the effect of formal sector employment is slightly stronger in rural areas than urban areas. This finding is in line with the fact that formal sector employment is lower in rural than urban areas. Comparing the effect 
on poverty of a signed working card in urban Pará and urban Brazil revel that a signed working card is a less strong shield against poverty in urban Pará than elsewhere in Brazil. Turning to the sector of employment - public, agriculture, services, industry, mining, social and other - is a significant correlate of poverty in Pará. Heads of households employed in mining have a lower likelihood of experiencing poverty than their counterparts employed in the public sector. This finding holds for both rural and urban areas and the impact on poverty is strongest in rural areas. This is household heads in rural areas employed in mining have the lowest probability of experiencing poverty of all sectors. Workers in industry have a higher probability of experiencing poverty in urban areas than public sector workers while workers in industry have a lower probability of experiencing poverty in rural areas than public sector workers.

Age of head of household and its members affect the likelihood of falling into poverty. The older the head of the household, the lower the probability the household will be poor, albeit at a decreasing rate (Tables 7.1 and 7.2). This may be an indication of increasing skills accumulation with age. Households with young children are the most poverty prone; households with old people are the least. In Pará's urban and rural areas, families with children younger than 5 appear more likely to be poor than families with no such children. One direct policy intervention would be to facilitate access to childcare. The poor find the shortage of affordable childcare a large obstacle to their daily chores. The gender findings paired with this small children finding indicate that single mothers with small children are far more likely to experience poverty than, for example, male-headed households with no children.

The likelihood of extreme poverty for households with youth members (aged 15 to 24) is much lower than for those with children younger than 5 and between 5 and 15, but it is still high. Additionally, this finding pared with the above-mentioned finding that young household heads are much more likely to experience poverty indicates that the youth are at considerable risk of poverty in Pará. The probability of extreme poverty is lowest for elder household heads and much lower in rural than urban areas. The lower likelihood of extreme poverty for households with a member older than 65 may be due to the fact that many of the elderly receive a pension, which would increase household income. Anecdotal evidence indicates that in many rural and remote areas, the only money circulating originates from some form of conditional cash transfer program (see above).

Size of household matters for poverty. Family characteristics, such as household size, are positively correlated with the incidence of poverty in rural and urban areas in Pará. Hence, the larger the household, the more poverty prone it is. Moreover, larger households in rural areas are poorer than in urban areas and the effect is concave, indicating that a scaling factor matters for poverty. In urban areas in Brazil and Pará, data do not reveal any significant difference between family size and poverty; poverty is increasing with family size everywhere in Brazil.

Although these findings help improve our understanding of the determinants of poverty, they do not all lead to policy recommendations. Some findings, such as those on race 
and gender are difficult to address, especially at the state level. ${ }^{11}$ However, many of these findings can assist in the formulation of poverty reduction recommendations and strategy in Pará. The location and education findings should be reflected in the infrastructure and education policies, respectively, while health policies relating to improving family planning and infant mortality should result in lower household sizes with fewer young children. Also, some of the social protection policies should be targeted at the vulnerable as identified in this section.

\section{Poverty Reduction Strategy for Pará}

Over the medium to longrun what is needed to alleviate the high levels of poverty and social exclusion is broad-based growth. However, this is not enough to alleviate poverty, particularly in the shortrun. Measures are needed to protect vulnerable groups and to ensure that the poor are able to take advantage of the greater opportunities in the economy. In order to address these latter needs, this paper has examined the profile of the poor in Pará and recommended priority policies and programs targeted to them.

The government of Pará has taken important steps to reduce poverty. For example recent programs, such as the Maria-Maria and Raizes programs, address the needs of vulnerable groups in Pará. However, Pará needs a poverty alleviation strategy that sets clear and appropriate priorities and goals for poverty reduction efforts within a framework of a continuation of economic policies that would promote growth. The challenge and test of the government's resolve will be to what extent current and future policies and programs are governed by that strategy. In order to ensure that the poor reap the benefits, poverty measurement and monitoring are called for, including tracking changes and making appropriate adjustments in existing programs and training staff to undertake activities to reflect these changes.

\section{A SIX-PRONGED APPROACH FOR PARÁ}

The poverty profile and determination of poverty provide guidance on a social agenda and poverty alleviation strategy for Pará. ${ }^{12}$ The strategic principles for reducing poverty involve seeking to strengthen the key assets of the poor, taking into account geographic differences in the poverty situation and priorities. The government of Pará could apply a six-pronged poverty-reduction approach: ${ }^{13}$

\footnotetext{
${ }^{11}$ Moreover, the findings on race could be slightly biased — the non-poor in Brazil have a tendency to classify themselves as white.

${ }^{12}$ It is worth to keep in mind that this paper is a fast assessment of poverty and exclusion in Pará and does by no means capture all areas of poverty in the state. Further research include: public expenditure analysis (incidence and management), the links between poverty, rural and urban living, health, and the environment, impact evaluations of social assistance programs, participatory research on the obstacles to increased school enrollment among black and mulatto children, and participatory research on poverty, crime and violence.

${ }^{13}$ Some key steps for immediate action could include: (1) conducting a thorough review of public expenditure allocations and developing proposals for reallocating expenditures such that they better reach the poor; (2) developing a set of indicators to monitor implementation of poverty reduction interventions (including key budget categories) and agreeing on an inter-institutional process for reporting on such indicators and implementation; and (3) applying a poverty map as a tool for targeting and resource allocation.
} 
First, targeted programs should focus on the extreme poor and prioritize among groups. Given the distribution of poverty, first priority should be given to female-headed households with young children, minorities including Indians, blacks, and pardos, people with or at risk for low education attainment, and urban and rural poor. Second priority should be assigned to programs that target poor informal sector workers and the unemployed poor. Improvements in social policies and access to public services are needed to reduce extreme poverty for these groups.

- The gender finding paired with the young children finding indicates that single mothers with small children are far more likely to experience poverty than, for example, male-headed households with no children. Social policies favoring women should be expanded, for example: (1) conditional-cash-transfer programs where the mother receives the benefit, and (2) more kindergarten and childcare facilities for poor mothers could facilitate poor women's labor market participation.

- Indians, blacks and pardos are poorer than whites. It would be more sensible to target social policies toward the poor rather than to consider affirmative action programs. Yet there is room for special actions to increase school attendance and improve the health of Indians, blacks and mulattos. In education one option would be to introduce schoolbooks and materials that better reflect the reality of Indians, blacks, and mulattos. In health, one option would be to give more attention to specific illnesses of black people, including training health staff in attending the special needs of the black population. Additionally, efforts to increase racial integration are called for.

- Extremely poor households are at great risk for poor or low human capital accumulation, including poor health and undesired pregnancies, because they lack access to family planning and clean water and sanitation facilities. They are also at risk for low-quality education and education attainment. Increased quality education and educational attainment can reduce the likelihood of becoming poor, as more education is a key factor in obtaining a higher income. Furthermore, education is associated with fertility: the more education a woman attains, the lower her fertility rate and, therefore, the lower the dependency ratio and the lower the likelihood of falling into poverty. It is clear that the Paraenses need to be brought up the educational ladder to escape poverty. One approach would be to increase: (1) access to early childhood development and daycare programs, (2) access of poor people to programs of financial transfers linked to early childhood development and secondary and higher education, and (3) quality of education.

- The differing characteristics of poor rural households call for multiple paths out of poverty aimed at: (i) small farm sector intensification, (ii) improved employment opportunities in dynamic commercial agriculture, (iii) growth of the rural non-farm sector, and (iv) provision of safety nets for those "trapped" in poverty. The recommended measures include improving human capital endowments, reforming the land, labor and financial markets, enhancing research and extension, assuring that all citizens have documents, improving the 
supply of public goods and services, pricing and trade policies, and transfer programs.

- Other households are poor because they are either in low-paying, lowproductivity jobs in the informal sector or unemployed. They need more productive jobs to raise their income above the poverty level and become well equipped to take advantage of employment opportunities. It should be recognized that since very few people work in the formal labor market, social policies tied to formal employment or unemployment will have only very limited reach among the poor. Social protection policies need to allow informal workers to take advantage of them, while simultaneous efforts need to be made to encourage formal sector growth and that may include liberalization of the labor market. Hence, the state government should support federal government initiatives to reform the labor code in order to reduce costs of employment creation in the formal sector. Possible measures would entail: (1) realigning incentives for hiring, retaining, and firing workers, and (2) relaxing rules, including mandated minimum non-wage benefits, to leave more to decentralized collective bargaining, and (3) targeted social protection measures that relate to informal sector and youth employment.

Second, the governments should reallocate public expenditures and promote community participation in service delivery. The top priority for effective action to reduce poverty should involve reallocating public expenditures. The government needs to reallocate existing spending toward areas that benefit the poor, boost cost recovery for services used by the non-poor, and improve efficiency in service delivery. A thorough review of public spending should be conducted to provide guidance on such reallocations. Clear candidates for reallocation of education spending include: (i) enforcing higher cost recovery for higher education and shifting freed resources toward basic education, kindergarten, and early childhood development; (ii) focusing spending on demand-side education schemes to reduce economic barriers faced by poor households to increase enrollment by the poor in secondary and tertiary education. Spending on social insurance and assistance should also be streamlined to ensure a comprehensive, efficient, well-targeted safety net. An inventory of service coverage should be overlayed with a poverty map to guide spending allocations on basic services so as to target key gaps among the poor. Promotion of community participation in service delivery is important to expand social programs and respond to community preferences for service delivery.

Third, the government should implement key policy reforms to reduce disparities in assets. Special efforts should be made to ensure that key reforms to reduce disparities in assets, and hence poverty, are undertaken, including: (i) supporting the federal government attempt to reform of the labor code; (ii) expanding house and land property titling; and (3) ensuring access to high-quality secondary and higher education for students from poor households.

Fourth, it should improve targeting mechanisms. The government should apply a poverty map to the allocation of expenditures. It should also seek to develop additional mechanisms for targeting, including means-testing and self-targeting. In this, it is key that all citizens have documents and are included in the government's systems. 
Fifth, Pará allocate resources to monitor poverty and evaluate the implementation of poverty reduction interventions. The government needs to develop a poverty monitoring system to track living conditions and provide data for impact evaluation of interventions. The government should also seek to develop a key set of indicators for monitoring actions to reduce poverty.

Sixth, it should increase sectoral integration. For the poverty-reduction strategy to be effective, a high level of sectoral integration is needed at all levels of government. It is of utmost importance that the Secretariat of Production works closely with other secretariats in the state so that all changes in poverty indicators are reflected in the social programs in Pará. 


\section{REFERENCES}

Amadeo, Edward Joaquim and_Marcelo Côrtes Neri ,2000 Macroeconomic Policy And Poverty In Brazil, Ensaios Econômicos da EPGE 373.

Atlas do Desenvolvimento Humano no Brasil (1970,1980, 1991). IBGE.

Blom, Andreas, and Carlos Vélez. 2001. "The Dynamics of the Skill-premium in Brazil; Growing Demand and Insufficient Supply?" Washington, D.C.: World Bank.

Blom, Andreas, Nina Pavcnik, and Norbert Schady. 2001. "Trade Liberalization and Labor Market Adjustment in Brazil.” Washington, D.C.: World Bank.

Census 2000. http://www.ibge.gov.br/home/estatistica/populacao/censo2000.

Currie, Janet. 2001. "Early Childhood Development Programs." Journal of Economic Perspectives, 15 (2) :213-38.

Ferreira and Leite, 2001. "Education Expantion and Income Distribution”, http://www.nipnetwork.org/panama_meeting_2002/leite.pdf.

Ferreira, Francisco, Peter Lanjouw, and Marcelo Neri. 1998. "The Urban Poor in Brazil in 1996: A New Poverty Profile Using PPV, PNAD and Census Data." A Background Paper for the World Bank's Urban Poverty Strategy Report.

Fiess, Norbert Mathias, and Dorte Verner. 2001. "The Dynamics of Poverty and its Determinants: The Case of Rio Grande do Norte and the Northeast of Brazil." Washington, D.C.: World Bank.

Foster, Greer, and Thorbecke (1984). "A class of decomposable poverty measures." Econometrica, 52, 761-65.

Elbers, C., J. Olson Lanjouw, P. Lanjouw and P. G. Leite (2001). "Poverty and Inequality in Brazil: Estimates from Combined PPV-PNAD Data." World Bank mimeo.

Heckman, James. 1999. "Policies to Foster Human Capital." Working Paper No. 7288. Cambridge, MA: National Bureau of Economic Research, August.

IBGE. Censo Agropecuário 1995-1996; “"Pesquisa Agrícola Municipal (PAM)”; Levantamento Sistemático da Produção Agrícola (LSPA).

. Contas Regionais do Brasil.

. Census 1970, 1980, and 2000.

. PNADs 1981-2001.

. "Síntese de Indicadores Sociais". 2000. 
World Bank. 1997. "Alcohol Policy as a Means of Controlling Crime and Violence: A Review of the Research.” Washington D.C.: World Bank. Unpublished. . 2000. "Brazil-Critical Issues in Social Security." Report No. 19641-BR. Washington, D.C.

—. 2001. “World Development Report 2000/2001.” Washington, D.C. . 2001a, "Rural Poverty Reduction in Brazil: Towards and Integrated Strategy." Report No. 21790-BR. Washington, D.C. 


\section{APPENDIX A}

\section{Population in Pará's 143 Municipalities (2000) Meso And Micro Regions And Respective Municipalities}

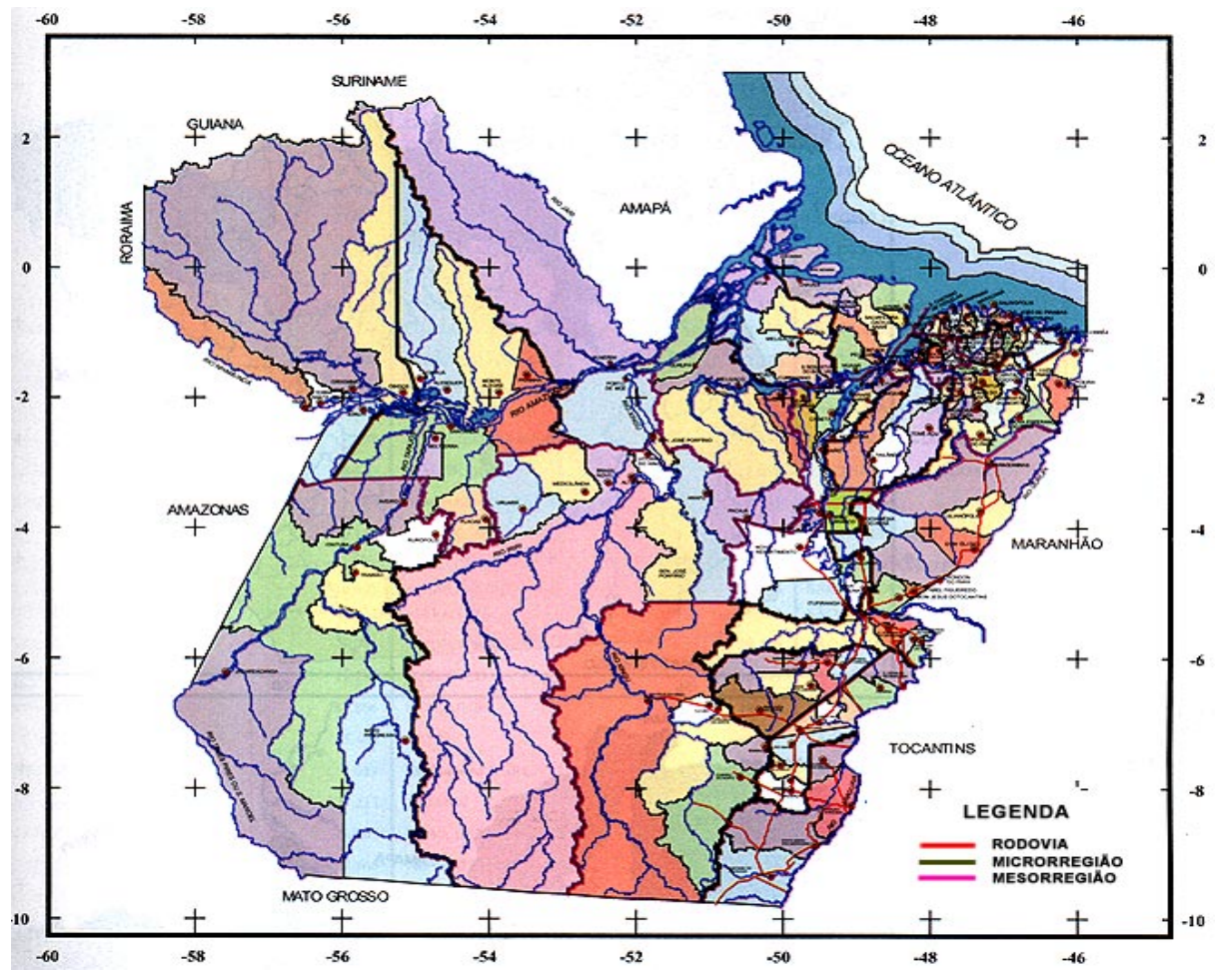

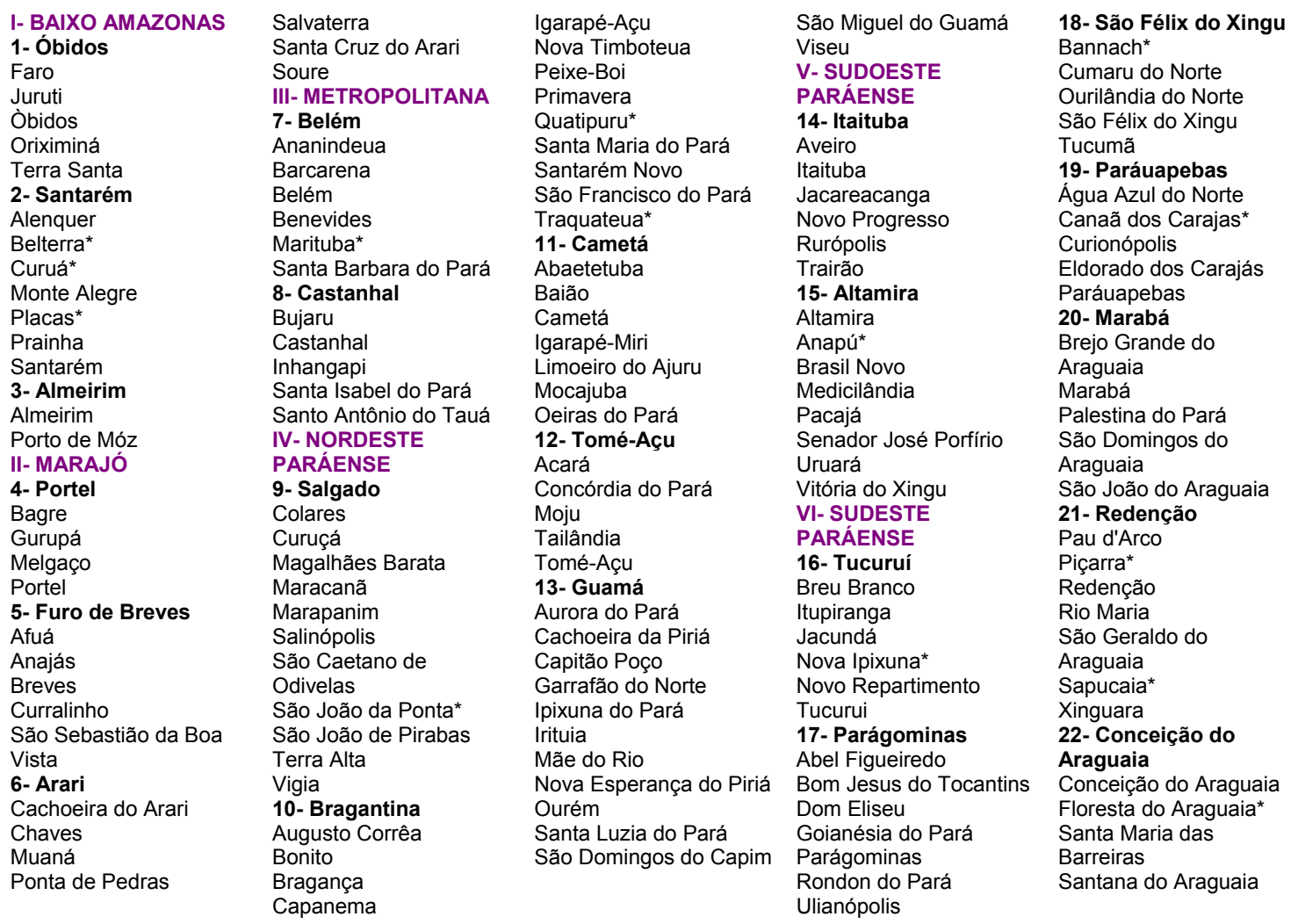


APPENDIX A continued

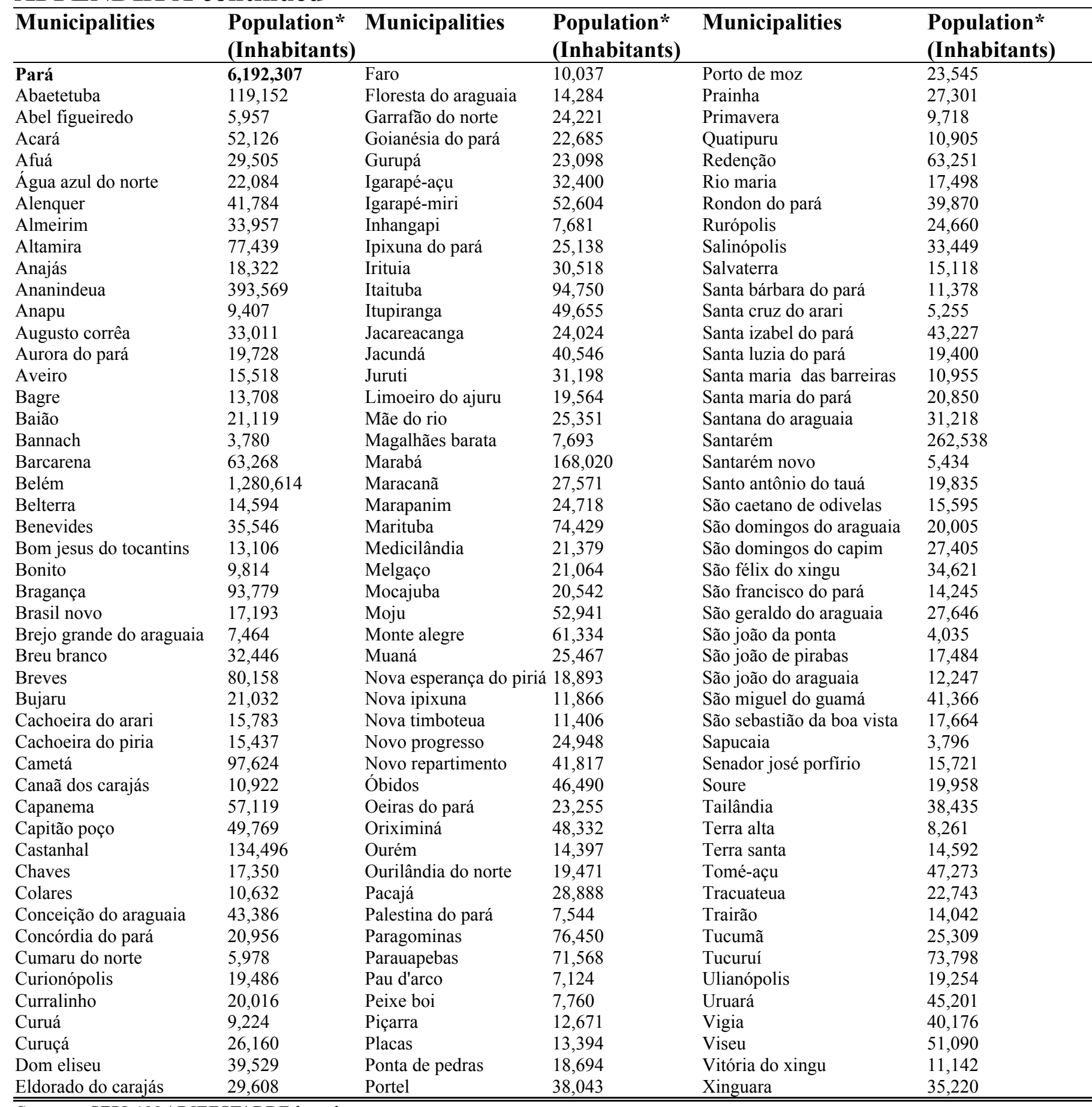

Source: : SEPLAN / DIEEST/ BDE based on

IBGE - censo 2000 


\section{APPENDIX B}

Poverty Indices for the Amazon and its states based on PNAD 1981-2001 (author'scalculations)

\begin{tabular}{|c|c|c|c|c|c|c|c|c|c|c|}
\hline $\mathbf{P 0}$ & 1981 & 1985 & 1990 & 1992 & 1993 & 1995 & 1997 & 1998 & 1999 & 2001 \\
\hline Brazil & 24.4 & 26.0 & 30.3 & 37.4 & 29.7 & 21.8 & 21.9 & 21.6 & 22.4 & 21.9 \\
\hline North & 23.7 & 22.7 & 29.0 & 43.7 & 40.6 & 30.6 & 33.4 & 34.2 & 33.3 & 30.1 \\
\hline Rondônia & 15.1 & 7.2 & 25.4 & 36.9 & 33.2 & 20.0 & 20.7 & 17.8 & 19.4 & 24.7 \\
\hline Acre & 30.6 & 19.1 & 34.9 & 36.6 & 35.1 & 21.2 & 30.5 & 25.6 & 29.6 & 28.6 \\
\hline Amazonas & 15.6 & 21.0 & 18.3 & 41.4 & 41.7 & 27.4 & 29.2 & 38.6 & 35.8 & 32.9 \\
\hline Roraima & 5.3 & 12.7 & 9.5 & 23.8 & 23.5 & 7.6 & 17.8 & 23.9 & 22.8 & 24.7 \\
\hline Pará & 28.7 & 27.6 & 37.0 & 45.2 & 41.8 & 32.7 & 35.4 & 35.2 & 35.4 & 33.0 \\
\hline Amapá & 30.3 & 20.9 & 23.5 & 37.3 & 34.4 & 25.0 & 37.0 & 34.9 & 34.7 & 12.2 \\
\hline Tocantins & & & & 55.6 & 47.3 & 47.1 & 45.0 & 41.7 & 37.4 & 26.4 \\
\hline $\mathbf{P 1}$ & 1981 & 1985 & 1990 & 1992 & 1993 & 1995 & 1997 & 1998 & 1999 & 2001 \\
\hline Brazil & 9.7 & 10.5 & 13.0 & 19.2 & 14.5 & 10.6 & 11.0 & 10.6 & 10.8 & 11.1 \\
\hline North & 7.9 & 8.0 & 11.4 & 22.0 & 18.3 & 13.9 & 15.8 & 15.8 & 15.6 & 14.5 \\
\hline Rondônia & 4.6 & 2.2 & 9.5 & 15.0 & 12.2 & 8.6 & 8.6 & 7.1 & 10.0 & 11.3 \\
\hline Acre & 11.2 & 6.3 & 14.0 & 18.6 & 15.4 & 10.4 & 17.8 & 12.0 & 14.4 & 15.0 \\
\hline Amazonas & 4.5 & 7.3 & 6.3 & 21.8 & 19.4 & 12.9 & 13.7 & 18.8 & 16.9 & 16.6 \\
\hline Roraima & 0.8 & 3.8 & 2.8 & 10.8 & 9.8 & 3.8 & 6.3 & 10.5 & 11.8 & 12.9 \\
\hline Pará & 10.0 & 9.9 & 15.2 & 22.3 & 19.3 & 14.2 & 16.6 & 15.6 & 16.0 & 15.6 \\
\hline Amapá & 10.3 & 7.4 & 9.0 & 17.6 & 15.1 & 10.7 & 19.4 & 18.9 & 17.7 & 6.9 \\
\hline Tocantins & & & & 31.0 & 21.7 & 22.7 & 21.6 & 19.4 & 17.2 & 11.8 \\
\hline $\mathbf{P 2}$ & 1981 & 1985 & 1990 & 1992 & 1993 & 1995 & 1997 & 1998 & 1999 & 2001 \\
\hline Brazil & 5.2 & 5.7 & 7.4 & 13.1 & 9.8 & 7.2 & 7.7 & 7.3 & 7.5 & 7.9 \\
\hline North & 3.7 & 3.9 & 5.9 & 15.0 & 11.8 & 9.2 & 10.9 & 10.7 & 10.7 & 10.0 \\
\hline Rondônia & 2.1 & 1.0 & 4.9 & 9.3 & 7.2 & 5.7 & 5.6 & 4.4 & 7.6 & 7.7 \\
\hline Acre & 5.8 & 3.2 & 7.6 & 13.3 & 10.2 & 7.4 & 13.4 & 8.4 & 9.9 & 10.8 \\
\hline Amazonas & 1.8 & 3.7 & 3.0 & 15.3 & 12.6 & 8.6 & 9.5 & 13.2 & 11.8 & 11.9 \\
\hline Roraima & 0.2 & 1.4 & 1.1 & 7.5 & 6.3 & 3.0 & 4.3 & 7.1 & 8.8 & 9.5 \\
\hline Pará & 4.8 & 4.8 & 8.1 & 14.9 & 12.6 & 9.3 & 11.4 & 10.5 & 10.8 & 10.6 \\
\hline Amapá & 4.8 & 3.9 & 4.4 & 11.9 & 8.7 & 6.5 & 14.3 & 14.6 & 12.7 & 5.5 \\
\hline Tocantins & & & & 21.6 & 13.9 & 15.5 & 14.5 & 12.6 & 11.2 & 7.7 \\
\hline $\begin{array}{l}\text { Mean Income of } \\
\text { the Poor }\end{array}$ & 1981 & 1985 & 1990 & 1992 & 1993 & 1995 & 1997 & 1998 & 1999 & 2001 \\
\hline Brazil & 39.2 & 38.8 & 37.1 & 31.6 & 33.3 & 33.4 & 32.4 & 33.1 & 33.7 & 31.9 \\
\hline North & 43.3 & 42.1 & 39.5 & 32.2 & 35.7 & 35.5 & 34.2 & 35.0 & 34.6 & 33.7 \\
\hline Rondônia & 45.4 & 45.1 & 40.6 & 38.6 & 41.0 & 37.0 & 38.0 & 39.3 & 31.4 & 35.1 \\
\hline Acre & 41.2 & 43.5 & 38.9 & 31.9 & 36.6 & 33.1 & 27.2 & 34.7 & 33.5 & 30.9 \\
\hline Amazonas & 46.4 & 42.2 & 42.5 & 30.7 & 34.8 & 34.4 & 34.6 & 33.3 & 34.3 & 32.2 \\
\hline Roraima & 54.6 & 45.7 & 45.6 & 35.5 & 37.8 & 32.1 & 42.2 & 36.6 & 31.5 & 31.0 \\
\hline Pará & 42.5 & 41.7 & 38.4 & 33.0 & 35.1 & 36.8 & 34.4 & 36.1 & 35.7 & 34.3 \\
\hline Amapá & 42.9 & 41.9 & 40.1 & 34.3 & 36.5 & 37.1 & 30.9 & 29.8 & 32.0 & 28.6 \\
\hline \multirow[t]{2}{*}{ Tocantins } & & & & 28.7 & 35.2 & 33.7 & 33.8 & 34.8 & 35.0 & 35.9 \\
\hline & & & & 58 & & & & & & \\
\hline
\end{tabular}




\section{APPENDIX C}

Education and Culture Spending (nominal R\$ million)

\begin{tabular}{|c|c|c|c|c|c|c|c|}
\hline & 1995 & 1996 & 1997 & 1998 & 1999 & 2000 & 2001 \\
\hline Brazil & $14,371.2$ & $17,172.4$ & $15,981.6$ & $22,872.9$ & $24,758.3$ & $27,962.2$ & $32,576.8$ \\
\hline North & $1,101.2$ & $1,278.1$ & $1,338.1$ & $1,657.5$ & $1,564.1$ & $1,916.2$ & $2,287.7$ \\
\hline Rondônia & 109.9 & 123.1 & 150.7 & 164.6 & 181.5 & 226.3 & 253.0 \\
\hline Acre & 82.6 & 97.7 & 112.0 & 169.3 & 129.8 & 183.4 & 201 \\
\hline Amazonas & 231.9 & 300.5 & 308.1 & 320.6 & 316.9 & 454.3 & 529 \\
\hline Roraima & 59.8 & 68.7 & 85.1 & 105.5 & 97.5 & 130.5 & 158 \\
\hline Pará & 343.1 & 425.6 & 433.2 & 603.0 & 525.6 & 533.1 & 66 \\
\hline Amapá & 165.2 & 122.7 & 103.7 & 127.2 & 129.4 & 153.8 & 185 \\
\hline Tocantins & 108.7 & 139.7 & 145.2 & 167.2 & 183.4 & 235.0 & 296 \\
\hline Northeast & $2,373.0$ & $2,684.1$ & $3,196.0$ & $4,103.8$ & $4,403.8$ & $4,518.1$ & 6,176 \\
\hline Maranhão & 255.5 & 323.2 & 287.1 & 293.2 & 350.2 & 301.2 & 695 \\
\hline Piauí & 152.1 & 192.8 & 171.2 & 190.3 & 276.9 & 264.2 & 350 \\
\hline Ceará & 342.1 & 292.6 & 440.0 & 597.2 & 609.1 & 763.6 & 1,123 \\
\hline Rio Grande do Norte & 162.5 & 190.1 & 224.5 & 390.9 & 407.5 & 471.6 & 575 \\
\hline Paraíba & 180.4 & 237.4 & 259.3 & 379.2 & 418.5 & 459.3 & 604 \\
\hline Pernambuco & 316.0 & 335.7 & 448.8 & 559.3 & 526.0 & 413.8 & 527 \\
\hline Alagoas & 136.3 & 154.9 & 118.7 & 179.5 & 227.6 & 261.0 & 320 \\
\hline Sergipe & 143.7 & 162.3 & 159.9 & 208.7 & 218.6 & 264.6 & 353 \\
\hline Bahia & 684.3 & 795.2 & $1,086.5$ & $1,305.4$ & $1,369.4$ & $1,318.9$ & 1,626 \\
\hline Southeast & $7,622.6$ & $8,809.6$ & $7,128.3$ & $11,872.2$ & $12,844.8$ & $14,994.0$ & 17,474 \\
\hline Gerais & $1,703.1$ & $1,860.2$ & $1,976.2$ & $3,104.3$ & $2,797.8$ & $3,324.3$ & 3,528 \\
\hline Espírito Santo & 216.2 & 240.6 & 249.3 & 460.9 & 439.0 & 301.7 & 353 \\
\hline Rio de Janeiro & $1,429.8$ & $1,559.9$ & $1,268.4$ & $2,245.8$ & $3,184.4$ & $3,722.7$ & 3,114 \\
\hline São Paulo & $4,273.5$ & $5,148.9$ & $3,634.4$ & $6,061.1$ & $6,423.5$ & $7,645.3$ & 10,478 \\
\hline South & $1,896.3$ & $2,871.1$ & $2,659.0$ & $3,436.3$ & $3,299.4$ & $4,169.8$ & 3,995 \\
\hline Paraná & 868.2 & $1,104.5$ & $1,239.9$ & $1,840.5$ & $1,712.2$ & $1,357.1$ & 1,492 \\
\hline Santa Catarina & 395.7 & 495.6 & 497.1 & 479.9 & 458.2 & 803.8 & 923 \\
\hline Rio Grande do Sul & 632.3 & $1,270.9$ & 922.0 & $1,115.9$ & $1,128.9$ & $2,008.9$ & 1,579 . \\
\hline Center-West & $1,378.1$ & $1,529.4$ & $1,660.2$ & $1,803.1$ & $2,646.3$ & $2,364.1$ & 2,643 \\
\hline Mato Grosso do Sul & 180.7 & 230.2 & 167.7 & 290.4 & 339.5 & 468.4 & 479 \\
\hline Mato Grosso & 285.3 & 231.2 & 297.5 & 274.2 & 385.8 & 332.9 & 335 \\
\hline Goiás & 294.6 & 385.2 & 392.8 & 492.4 & 484.2 & 596.3 & 808 \\
\hline Distrito Federal & 617.5 & 682.8 & 802.2 & 746.1 & $1,436.8$ & 966.5 & 1,020 \\
\hline
\end{tabular}

http://www.stn.fazenda.gov.br/estados municipios/index.asp 


\section{APPENDIX C (continued 2)}

Education and Culture Spending (GDP)

\begin{tabular}{|c|c|c|c|c|c|c|c|c|}
\hline & & 1995 & 1996 & 1997 & 1998 & 1999 & 2000 & 2001 \\
\hline Brazil & TOTAL & 2.2 & 2.2 & 1.8 & 2.5 & 2.5 & 2.5 & na \\
\hline North & $\mathbf{N}$ & 3.7 & 3.5 & 3.5 & 4.0 & 3.6 & 3.8 & na \\
\hline Rondônia & $\mathrm{RO}$ & 3.7 & 3.4 & 3.6 & 3.6 & 3.6 & 4.0 & na \\
\hline Acre & $\mathrm{AC}$ & 8.3 & 8.5 & 8.5 & 11.6 & 8.3 & 10.8 & na \\
\hline Amazonas & $\mathrm{AM}$ & 2.1 & 2.1 & 2.1 & 2.1 & 2.0 & 2.4 & na \\
\hline Roraima & $\mathrm{RR}$ & 12.7 & 12.6 & 13.7 & 14.1 & 11.9 & 11.7 & na \\
\hline Pará & PA & 2.8 & 3.1 & 2.9 & 3.9 & 3.2 & 2.8 & na \\
\hline Amapá & AP & 13.4 & 9.2 & 6.8 & 8.5 & 8.2 & 7.8 & na \\
\hline Tocantins & TO & 8.9 & 9.1 & 8.4 & 8.6 & 8.7 & 9.6 & na \\
\hline Northeast & NE & 2.9 & 2.6 & 2.8 & 3.4 & 3.4 & 3.1 & na \\
\hline Maranhão & MA & 5.0 & 4.7 & 3.9 & 4.1 & 4.4 & 3.3 & na \\
\hline Piauí & PI & 4.8 & 4.9 & 4.1 & 4.3 & 5.8 & 5.0 & na \\
\hline Ceará & $\mathrm{CE}$ & 2.7 & 1.9 & 2.5 & 3.2 & 3.1 & 3.7 & na \\
\hline Rio Grande do Norte & $\mathrm{RN}$ & 3.4 & 3.2 & 3.4 & 5.7 & 5.3 & 5.1 & na \\
\hline Paraíba & PB & 3.4 & 3.6 & 3.7 & 5.2 & 5.3 & 5.0 & na \\
\hline Pará & $\mathrm{PE}$ & 1.8 & 1.6 & 1.9 & 2.3 & 2.0 & 1.4 & na \\
\hline Alagoas & $\mathrm{AL}$ & 3.4 & 3.1 & 2.1 & 2.9 & 3.5 & 3.7 & na \\
\hline Sergipe & SE & 4.1 & 3.8 & 3.3 & 4.1 & 4.0 & 4.5 & na \\
\hline Bahia & BA & 2.6 & 2.4 & 2.9 & 3.4 & 3.3 & 2.7 & na \\
\hline Southeast & SE & 2.0 & 1.9 & 1.4 & 2.2 & 2.3 & 2.4 & na \\
\hline Minas Gerais & $\mathrm{MG}$ & 2.7 & 2.4 & 2.3 & 3.5 & 3.0 & 3.1 & na \\
\hline Espírito Santo & ES & 1.7 & 1.6 & 1.5 & 2.7 & 2.3 & 1.4 & na \\
\hline Rio de Janeiro & RJ & 1.9 & 1.8 & 1.3 & 2.2 & 2.8 & 2.7 & na \\
\hline São Paulo & SP & 1.9 & 1.9 & 1.2 & 1.9 & 1.9 & 2.1 & na \\
\hline South & $\mathbf{S}$ & 1.6 & 2.0 & 1.7 & 2.2 & 1.9 & 2.2 & na \\
\hline Paraná & PR & 2.3 & 2.3 & 2.3 & 3.2 & 2.8 & 2.1 & na \\
\hline Santa Catarina & $\mathrm{SC}$ & 1.7 & 1.7 & 1.6 & 1.5 & 1.3 & 1.9 & na \\
\hline Rio Grande do Sul & $\mathrm{RS}$ & 1.2 & 2.0 & 1.3 & 1.6 & 1.5 & 2.4 & na \\
\hline Center-West & $\mathrm{CO}$ & 3.6 & 3.2 & 3.1 & 2.9 & 4.2 & 3.1 & na \\
\hline Mato Grosso do Sul & MS & 2.6 & 2.8 & 1.8 & 2.9 & 3.1 & 3.9 & na \\
\hline Mato Grosso & MT & 4.4 & 2.9 & 3.2 & 2.8 & 3.3 & 2.5 & na \\
\hline Goiás & $\mathrm{GO}$ & 2.5 & 2.6 & 2.5 & 2.8 & 2.7 & 2.8 & na \\
\hline Distrito Federal & DF & 4.7 & 4.1 & 4.0 & 3.0 & 6.5 & 3.3 & na \\
\hline
\end{tabular}




\section{APPENDIX C (continued)}

Education and Culture Spending (\%Total Spending)

\begin{tabular}{|c|c|c|c|c|c|c|c|}
\hline & 1995 & 1996 & 1997 & 1998 & 1999 & 2000 & 2001 \\
\hline Brazil & 16.8 & 16.8 & 10.0 & 16.0 & 17.8 & 18.5 & 19.0 \\
\hline North & 19.1 & 19.1 & 19.9 & 19.3 & 19.6 & 20.3 & 19.7 \\
\hline Rondônia & 16.7 & 18.6 & 21.5 & 11.2 & 20.6 & 19.7 & 19.5 \\
\hline Acre & 17.1 & 21.4 & 22.0 & 26.6 & 19.2 & 23.3 & 21.6 \\
\hline Amazonas & 13.3 & 15.0 & 17.1 & 16.7 & 15.7 & 20.0 & 16.4 \\
\hline Roraima & 20.9 & 21.3 & 21.5 & 24.6 & 22.3 & 21.0 & 22.7 \\
\hline Pará & 22.8 & 22.6 & 20.9 & 21.6 & 20.2 & 18.7 & 19.6 \\
\hline Amapá & 28.4 & 25.6 & 23.9 & 27.2 & 25.5 & 26.1 & 24.0 \\
\hline Tocantins & 20.9 & 15.9 & 18.5 & 19.4 & 21.0 & 20.3 & 22.5 \\
\hline Northeast & 17.9 & 16.2 & 16.8 & 15.7 & 17.9 & 17.9 & 19.0 \\
\hline Maranhão & 24.6 & 22.8 & 23.2 & 21.1 & 16.5 & 13.9 & 23.5 \\
\hline Piauí & 18.0 & 20.3 & 16.1 & 17.2 & 23.5 & 21.4 & 22.3 \\
\hline Ceará & 17.5 & 12.4 & 16.1 & 17.3 & 12.5 & 19.4 & 21.4 \\
\hline Rio Grande do Norte & 19.5 & 17.9 & 16.0 & 20.0 & 23.5 & 24.1 & 25.1 \\
\hline Paraíba & 19.5 & 21.6 & 21.2 & 23.6 & 24.3 & 23.9 & 23.7 \\
\hline Pernambuco & 14.6 & 12.2 & 15.9 & 11.0 & 14.9 & 8.8 & 8.4 \\
\hline Alagoas & 19.9 & 12.4 & 14.4 & 17.8 & 17.6 & 17.4 & 22.1 \\
\hline Sergipe & 16.9 & 15.6 & 11.7 & 13.1 & 15.9 & 18.0 & 20.6 \\
\hline Bahia & 17.1 & 17.1 & 17.2 & 14.4 & 20.2 & 20.7 & 19.2 \\
\hline Southeast & 16.4 & 16.7 & 6.9 & 16.6 & 18.5 & 19.3 & 20.4 \\
\hline Minas Gerais & 18.0 & 19.7 & 16.4 & 19.9 & 28.5 & 22.9 & 20.7 \\
\hline Espírito Santo & 10.3 & 9.9 & 9.3 & 14.4 & 14.6 & 8.8 & 9.8 \\
\hline Rio de Janeiro & 18.1 & 15.0 & 10.4 & 16.3 & 19.9 & 22.5 & 17.5 \\
\hline São Paulo & 15.8 & 16.8 & 4.7 & 15.6 & 15.9 & 17.7 & 22.2 \\
\hline South & 15.0 & 16.9 & 13.7 & 13.9 & 13.8 & 16.3 & 15.8 \\
\hline Paraná & 25.1 & 24.3 & 22.0 & 22.1 & 15.3 & 13.9 & 16.6 \\
\hline Santa Catarina & 15.1 & 12.4 & 12.0 & 13.6 & 12.1 & 14.4 & 18.6 \\
\hline Rio Grande do Sul & 9.6 & 15.1 & 9.6 & 8.7 & 12.7 & 19.7 & 13.9 \\
\hline Center-West & 18.7 & 16.7 & 16.4 & 15.4 & 19.7 & 17.6 & 16.5 \\
\hline Mato Grosso do Sul & 17.5 & 16.3 & 11.2 & 16.2 & 21.1 & 23.0 & 20.2 \\
\hline Mato Grosso & 18.8 & 13.7 & 16.5 & 12.1 & 18.7 & 13.7 & 12.7 \\
\hline Goiás & 16.3 & 16.2 & 14.6 & 14.6 & 14.5 & 18.7 & 16.3 \\
\hline Distrito Federal & 20.4 & 18.6 & 19.4 & 17.3 & 22.4 & 16.7 & 16.9 \\
\hline
\end{tabular}




\section{APPENDIX D}

Monthly Income of Household Head by Level of Education and Gender, 2000

\begin{tabular}{|c|c|c|c|c|c|c|c|c|c|}
\hline \multirow[b]{2}{*}{$\begin{array}{l}\text { Years of schooling } \\
\text { of the Household } \\
\text { heads }\end{array}$} & \multicolumn{8}{|c|}{ Monthly Income Categories } & \multirow[b]{2}{*}{ Total } \\
\hline & $\begin{array}{l}\text { Less than } 1 / 2 \\
\text { minimum } \\
\text { salary }\end{array}$ & $\begin{array}{c}1 / 2<x<1 \\
\text { minimum } \\
\text { salary }\end{array}$ & $\begin{array}{c}1<\mathbf{x}<2 \\
\text { minimum } \\
\text { salary }\end{array}$ & $\begin{array}{c}2<x<5 \\
\text { minimum } \\
\text { salary }\end{array}$ & $\begin{array}{c}5<x<10 \\
\text { minimum } \\
\text { salary }\end{array}$ & $\begin{array}{c}10<x<20 \\
\text { minimum } \\
\text { salary }\end{array}$ & $\begin{array}{l}\text { More than } 20 \\
\text { minimum } \\
\text { salary }\end{array}$ & $\begin{array}{c}\text { No } \\
\text { Income }\end{array}$ & \\
\hline Male & 3.8 & 25.4 & 26.0 & 20.3 & 8.4 & 3.6 & 1.9 & 10.7 & 100.0 \\
\hline Female & 3.3 & 37.0 & 19.7 & 14.0 & 6.5 & 2.8 & 1.1 & 15.5 & 100.0 \\
\hline $\begin{array}{l}\text { No schooling and } \\
\text { less than } 1 \text { year }\end{array}$ & 5.6 & 45.6 & 22.6 & 8.2 & 1.9 & 0.5 & 0.2 & 15.5 & 100.0 \\
\hline 1 to 3 years & 5.5 & 35.6 & 27.1 & 13.8 & 3.5 & 1.0 & 0.4 & 13.0 & 100.0 \\
\hline 4 to 7 years & 3.3 & 25.2 & 28.7 & 21.4 & 6.6 & 2.0 & 0.8 & 12.1 & 100.0 \\
\hline 8 to 10 years & 1.4 & 15.7 & 26.3 & 30.3 & 11.4 & 3.5 & 1.5 & 9.8 & 100.0 \\
\hline 11 to 14 years & 0.5 & 7.2 & 17.7 & 32.9 & 22.2 & 9.7 & 3.7 & 6.2 & 100.0 \\
\hline 15 years or more & 0.1 & 1.3 & 2.9 & 11.2 & 27.3 & 29.3 & 24.8 & 3.1 & 100.0 \\
\hline
\end{tabular}

Source: Census 2000. 
APPENDIX E

Urban Poverty Profile from Census 2000

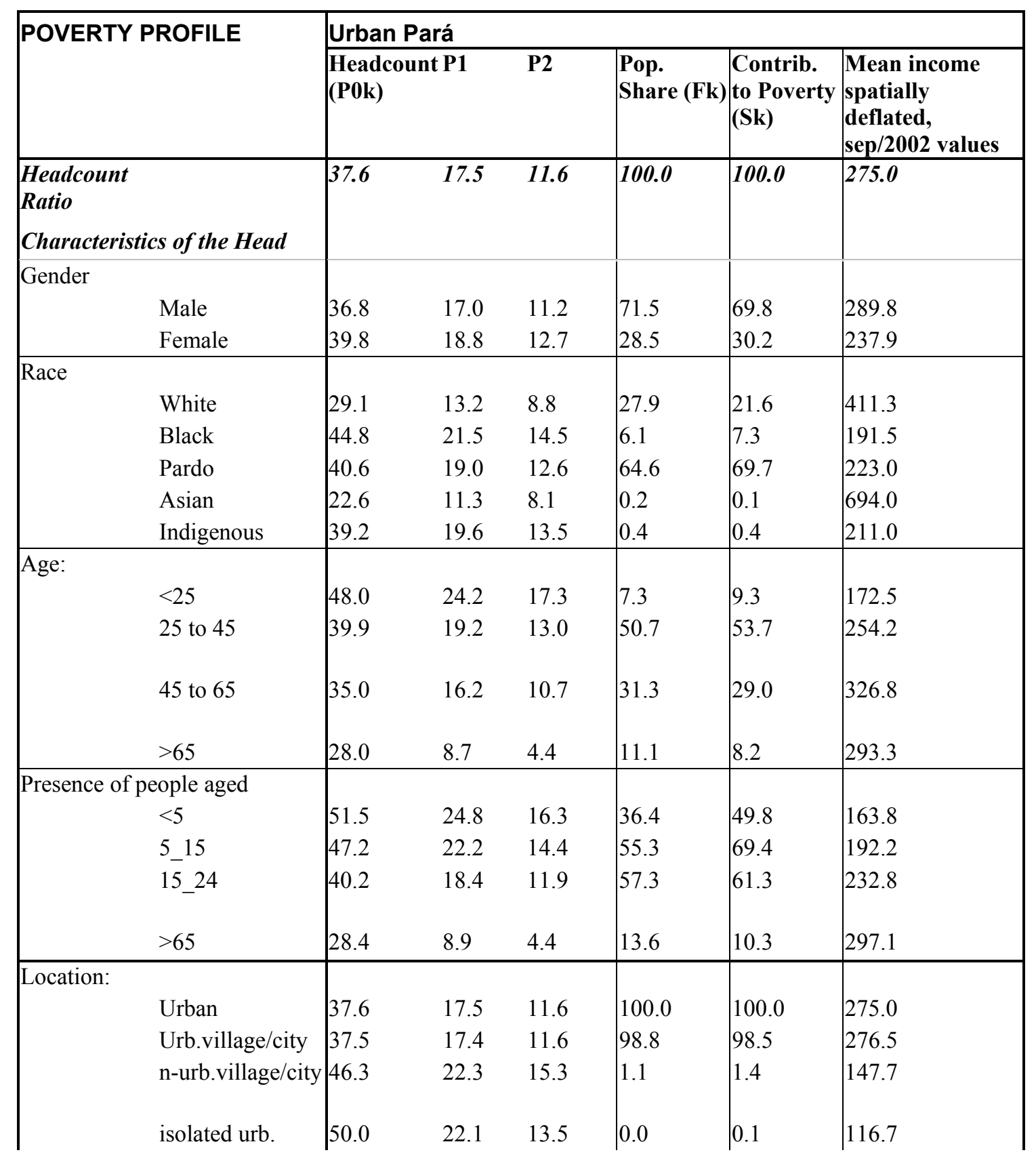




\section{APPENDIX E (continued)}

\begin{tabular}{|c|c|c|c|c|c|c|c|}
\hline \multicolumn{2}{|c|}{ Working Class: } & & \multirow[b]{2}{*}{43.3} & \multirow[b]{2}{*}{34.5} & \multirow[b]{2}{*}{286.4} \\
\hline Signed & Yes & 25.4 & 7.9 & 3.5 & & & \\
\hline & No & 37.0 & 14.4 & 7.6 & 56.7 & 65.5 & 251.5 \\
\hline \multirow[t]{2}{*}{ Working } & Yes & 31.7 & 12.0 & 6.3 & 69.0 & 58.1 & 316.8 \\
\hline & No & 51.0 & 29.9 & 23.6 & 31.0 & 41.9 & 181.9 \\
\hline \multirow[t]{7}{*}{ Work Sector } & Primary & 55.3 & 27.2 & 17.7 & 11.3 & 19.3 & 171.0 \\
\hline & Mineral Ind. & 24.1 & 8.9 & 4.7 & 0.5 & 0.4 & 297.1 \\
\hline & Secondary & 36.6 & 13.1 & 6.6 & 21.5 & 24.3 & 217.9 \\
\hline & Services & 29.6 & 11.0 & 5.7 & 46.2 & 42.3 & 344.6 \\
\hline & Social & 17.3 & 5.6 & 2.6 & 7.2 & 3.8 & 481.3 \\
\hline & Public & 17.8 & 6.3 & 3.1 & 8.4 & 4.6 & 446.8 \\
\hline & Other & 48.3 & 27.5 & 21.3 & 33.0 & 42.3 & 196.5 \\
\hline \multirow{4}{*}{$\begin{array}{l}\text { Work } \\
\text { Position }\end{array}$} & Employee & 32.0 & 11.6 & 5.8 & 60.0 & 59.3 & 266.6 \\
\hline & Self-employed & 33.6 & 13.6 & 7.5 & 34.9 & 36.2 & 280.2 \\
\hline & Employer & 5.9 & 1.9 & 0.9 & 3.4 & 0.6 & 1565.1 \\
\hline & Unpaid & 75.8 & 53.1 & 44.8 & 1.6 & 3.8 & 80.9 \\
\hline \multicolumn{8}{|l|}{ Education: } \\
\hline \multicolumn{8}{|c|}{ Read and Write } \\
\hline & Yes & 34.1 & 15.8 & 10.5 & 85.6 & 77.6 & 302.8 \\
\hline & No & 58.4 & 27.7 & 18.4 & 14.4 & 22.4 & 109.7 \\
\hline \multicolumn{8}{|c|}{ Years of Schooling: } \\
\hline & $\begin{array}{l}\text { No education o } \\
<1\end{array}$ & 55.7 & 25.9 & 17.1 & 13.2 & 19.5 & 114.6 \\
\hline & 1 to 4 & 46.8 & 22.0 & 14.5 & 35.9 & 44.6 & 161.3 \\
\hline & 4 to 8 & 37.9 & 17.5 & 11.7 & 23.5 & 23.7 & 207.2 \\
\hline & 8 to 12 & 19.2 & 8.6 & 6.0 & 20.8 & 10.6 & 393.6 \\
\hline & More than 12 & 3.6 & 2.0 & 1.6 & 5.9 & 0.6 & 1198.0 \\
\hline & NA & 49.6 & 24.6 & 16.8 & 0.7 & 0.9 & 176.4 \\
\hline
\end{tabular}


APPENDIX F

Rural Poverty Profile based on Census 2000

\begin{tabular}{|c|c|c|c|c|c|c|c|}
\hline \multirow{2}{*}{\multicolumn{2}{|c|}{ POVERTY PROFILE }} & \multicolumn{6}{|c|}{ Rural Pará } \\
\hline & & \multicolumn{2}{|c|}{$\begin{array}{l}\text { Headcount P1 } \\
\text { (P0k) }\end{array}$} & & \multirow{2}{*}{\begin{tabular}{|l|}
$\begin{array}{l}\text { Pop. } \\
\text { Share (Fk) }\end{array}$ \\
100.0 \\
\end{tabular}} & \multirow{2}{*}{\begin{tabular}{|l|}
$\begin{array}{l}\text { Contrib. } \\
\text { to Poverty } \\
\text { (Sk) }\end{array}$ \\
100.0
\end{tabular}} & \multirow{2}{*}{\begin{tabular}{|l|}
$\begin{array}{l}\text { Mean income } \\
\text { spatially } \\
\text { deflated, } \\
\text { sep/2002 values }\end{array}$ \\
136.4
\end{tabular}} \\
\hline \begin{tabular}{|l} 
Headcount \\
Ratio
\end{tabular} & & 58.4 & 33.8 & & & & \\
\hline \multicolumn{8}{|c|}{$\begin{array}{l}\text { Characteristics of the Head } \\
\text { Gender }\end{array}$} \\
\hline & Male & 59.1 & 34.3 & 25.1 & 90.6 & 91.8 & 137.2 \\
\hline & Female & 51.0 & 28.2 & 20.2 & 9.4 & 8.2 & 128.1 \\
\hline \multicolumn{8}{|l|}{ Race } \\
\hline & White & 49.5 & 27.9 & 20.2 & 21.0 & 17.8 & 208.0 \\
\hline & Black & 59.4 & 34.4 & 25.3 & 9.5 & 9.7 & 120.3 \\
\hline & Pardo & 60.8 & 35.1 & 25.6 & 66.9 & 69.7 & 116.7 \\
\hline & Asian & 31.1 & 18.2 & 13.4 & 0.2 & 0.1 & 368.6 \\
\hline & Indigenous & 75.9 & 58.5 & 51.6 & 1.2 & 1.6 & 69.1 \\
\hline \multicolumn{8}{|l|}{ Age: } \\
\hline & $<25$ & 61.8 & 36.8 & 28.1 & 8.4 & 8.9 & 101.1 \\
\hline & 25 to 45 & 64.9 & 38.8 & 28.8 & 48.8 & 54.2 & 123.9 \\
\hline & 45 to 65 & 57.1 & 32.3 & 23.4 & 32.2 & 31.3 & 159.1 \\
\hline & $>65$ & 30.4 & 12.9 & 7.5 & 10.9 & 5.7 & 153.3 \\
\hline \multicolumn{8}{|c|}{ Presence of people aged } \\
\hline & $<5$ & 74.6 & 44.1 & 32.1 & 46.1 & 58.9 & 85.1 \\
\hline & 5_15 & 70.4 & 40.8 & 29.4 & 61.0 & 73.6 & 93.5 \\
\hline & $15 \overline{5} 24$ & 63.1 & 35.7 & 25.7 & 57.4 & 62.1 & 112.5 \\
\hline & $>6 \overline{5}$ & 34.3 & 14.6 & 8.4 & 12.8 & 7.5 & 148.9 \\
\hline \multicolumn{8}{|l|}{ Location: } \\
\hline & Rural & 58.4 & 33.8 & 24.7 & 100.0 & 100.0 & 136.4 \\
\hline & Urban extension & 43.9 & 22.3 & 15.7 & 0.6 & 0.4 & 201.8 \\
\hline & povoado & 52.6 & 29.6 & 21.3 & 16.5 & 14.9 & 144.6 \\
\hline & núcleo & 15.5 & 6.7 & 4.1 & 2.2 & 0.6 & 587.0 \\
\hline & outros aglom. & 0.0 & 0.0 & 0.0 & 0.0 & 0.0 & 0.0 \\
\hline & excl. aglom. & 60.8 & 35.4 & 26.0 & 80.7 & 84.1 & 122.1 \\
\hline \multicolumn{8}{|c|}{ Working Class: } \\
\hline \multirow{2}{*}{$\begin{array}{l}\text { Signed } \\
\text { Worksheet }\end{array}$} & Yes & 34.8 & 13.2 & 6.6 & 28.4 & 21.5 & 265.5 \\
\hline & No & 50.7 & 22.2 & 12.4 & 71.6 & 78.5 & 141.8 \\
\hline
\end{tabular}




\section{APPENDIX F (continued)}

\begin{tabular}{|c|c|c|c|c|c|c|c|}
\hline \multirow[t]{2}{*}{ Working } & Yes & 54.2 & 26.2 & 15.9 & 71.2 & 66.0 & $\mid 163.6$ \\
\hline & No & 68.8 & 52.4 & 46.3 & 28.8 & 34.0 & 69.3 \\
\hline \multirow[t]{7}{*}{ Work Sector } & Primary & 63.5 & 36.9 & 26.7 & 69.4 & 75.8 & 115.6 \\
\hline & Mineral Ind. & 10.1 & 4.1 & 2.4 & 2.0 & 0.3 & 517.5 \\
\hline & Secondary & 55.1 & 26.1 & 15.6 & 13.0 & 12.3 & 161.2 \\
\hline & Services & 43.0 & 19.1 & 11.1 & 9.8 & 7.3 & 247.6 \\
\hline & Social & 34.1 & 12.4 & 5.9 & 1.8 & 1.1 & 238.7 \\
\hline & Public & 47.7 & 18.8 & 9.5 & 1.3 & 1.1 & 228.7 \\
\hline & Other & 58.1 & 39.4 & 32.8 & 21.2 & 21.1 & 96.4 \\
\hline \multirow{4}{*}{$\begin{array}{l}\text { Work } \\
\text { Position }\end{array}$} & Employee & 46.2 & 19.6 & 10.8 & 27.3 & 21.7 & 177.0 \\
\hline & Self-employed & 59.1 & 29.9 & 18.7 & 58.9 & 59.9 & 138.3 \\
\hline & Employer & 14.4 & 5.5 & 3.0 & 1.8 & 0.5 & 778.4 \\
\hline & Unpaid & 87.5 & 74.5 & 69.1 & 11.9 & 18.0 & 30.5 \\
\hline \multicolumn{8}{|l|}{ Education: } \\
\hline \multicolumn{8}{|c|}{ Read and Write } \\
\hline & Yes & 56.1 & 31.9 & 23.1 & 63.2 & 60.7 & 159.9 \\
\hline & No & 62.4 & 37.0 & 27.4 & 36.8 & 39.3 & 96.0 \\
\hline \multicolumn{8}{|c|}{ Years of Schooling: } \\
\hline & $\begin{array}{l}\text { No education or } \\
<1\end{array}$ & 61.6 & 36.3 & 26.8 & 33.7 & 35.5 & 101.3 \\
\hline & 1 to 4 & 60.7 & 35.0 & 25.4 & 49.9 & 51.9 & 118.2 \\
\hline & 4 to 8 & 49.6 & 27.7 & 20.2 & 10.8 & 9.2 & 179.5 \\
\hline & 8 to 12 & 27.4 & 13.5 & 9.4 & 3.6 & 1.7 & 362.1 \\
\hline & More than 12 & 7.0 & 4.2 & 3.3 & 0.5 & 0.1 & 1879.8 \\
\hline & NA & 64.5 & 37.1 & 26.8 & 1.3 & 1.5 & 102.2 \\
\hline
\end{tabular}

WB105749

C: \a- word \my papers \Pará paper\PARÁ POVERTY ASSESSMENT-WP-155March04.doc April 14, 2004 11:00 AM 